UNIVERSIDADE FEDERAL DE JUIZ DE FORA

GLÁUCIA DA SILVA PINHEIRO

Psicanálise e Educação:

da sustentação do enigma à construção do saber

Juiz de Fora, 15 de agosto de 2011 
Pinheiro, Gláucia da Silva.

Psicanálise e educação: da sustentação do enigma à construção do saber / Gláucia da Silva Pinheiro. - 2011.

$125 \mathrm{f}$.

Dissertação (Mestrado em Comunicação Social)-Universidade Federal de Juiz de Fora, Juiz de Fora, 2011.

1. Psicanálise. 2. Educação I. Título. 


\author{
UFJF - Faculdade de Educação \\ PPGE - Programa de Pós-graduação em Educação
}

\title{
Psicanálise e Educação: \\ da sustentação do enigma à construção do saber
}

\begin{abstract}
Dissertação de Mestrado apresentada ao Curso de Mestrado do Programa de Pós-graduação em Educação: linha de pesquisa em Linguagem, Conhecimento e Formação de Professores, da Faculdade de Educação da Universidade Federal de Juiz de Fora, como requisito parcial para obtenção do grau de Mestre em Educação.
\end{abstract}

Mestranda: Gláucia da Silva Pinheiro Orientadora: Professora Doutora Ana Maria de Moraes Fontes 


\section{Sumário}

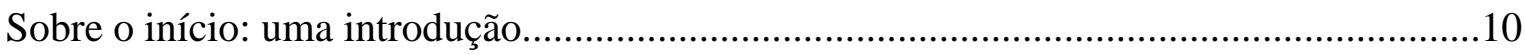

De um encontro singular com a Psicanálise a um reencontro com a Educação...................15

A Psicanálise na escuta da Educação: um lugar para a transferência..................................44

A criança e o saber: sustentando a dimensão do enigma...............................................71

Educação: Ensino e/ou Transmissão? Os giros discursivos e a formação...........................92

Momento de concluir.......................................................................................111

Bibliografia e referências bibliográficas.................................................................118 


\section{Resumo}

O presente ensaio traz articulações importantes quanto à interlocução entre os campos da Psicanálise e da Educação, campos que diante de um primeiro olhar nada apresentam de comum, mas que trazem no seu cerne a linguagem e o saber. Lançar um olhar sobre a Educação, à luz da Psicanálise, tendo como esteio aquilo que este campo traz de inédito no meu discurso, ou seja, sua relação com o saber, aponta algo novo nessa interlocução. Não se trata aqui de apontar caminhos, oferecer novas técnicas e modos de solucionar os problemas educacionais. A psicanálise entra aqui, nessa interlocução, como um novo discurso e, a partir do seu atravessamento no campo da educação, traz uma nova possibilidade de escuta, de posição diante da árdua tarefa de educar. Traz uma possibilidade de reflexão e de questionamento sobre a posição e a formação daqueles que ocupam um lugar tão importante e de tanto destaque na economia psíquica do sujeito infantil. Esse ensaio é endereçado a todos aqueles, professores ou leigos, educadores que estão às voltas com suas questões e seus embaraços frente ao ato educativo. As questões que direcionam esse estudo abordam a obra freudiana naquilo que ela toca o campo da educação, a partir da posição de Freud frente à causa psicanalítica e ao campo educacional. E o conceito fundamental da transferência, que tanto na intensão, quanto na extensão e na interlocução com outros campos de saber, é o sustentáculo da prática e do ensino da experiência psicanalítica, articula-se aí, tendo também um lugar na educação. Passeamos pela transferência, pelo infantil, a sexualidade, o complexo de Édipo, a sustentação do enigma, a diferença, a queda de certos ideais, o saber inconsciente, o ensino, a transmissão, a formação, a impossibilidade, trazendo o discurso analítico como articulador dessa amarração, apostando na possibilidade de se trabalhar na educação pela via da construção do saber. Sustentaremos aqui uma aposta. Aposta de que tal interlocução entre Psicanálise e Educação, entre psicanalistas e educadores, possa ter efeitos e possibilitar deslocamentos de discurso. Não se espera uma resposta para as questões levantadas, nem mesmo um arremate que feche a discussão. Esperamos, sim, manter abertas as lacunas que nos permitem avançar e sustentar sempre uma pergunta quanto à arte de educar. 


\section{Résumé}

Cet étude apporte des articulations importantes en ce qui concerne le dialogue entre les champs de la Psychanalyse et de l'Éducation, deux champs qui semblent n'avoir rien en commun, mais au sein desquels on trouve la langage et le savoir. Proposer un regard sur l'Éducation à la lumière de la Psychanalyse ayant comme base ce qui la Psychanalyse apporte comme inédit dans mon discours, c'est-à-dire sa relation avec le savoir, nous montre des éléments nouveaux dans cette interlocution. Il ne s'agit pas de montrer les chemins, offrir des nouvelles techniques ou des formules pour résoudre les problèmes de l'éducation. Le rôle de la psychanalyse ici est l'introduction d'un nouveau discours et une nouvelle possibilité d'écoute, de position devant la tâche difficile d'enseigner dès le croisement de ces deux champs. C'est une occasion de réfléchir et de poser des questions sur la position et la formation de ceux qui occupent une place si importante et remarquable dans l'économie psychique du sujet infantile. Cet étude s'adresse à tous les enseignants, éducateurs ou amateurs, enfin à tous ceux qui restent avec des questions et des embarras devant l'enseignement. Les questions de cet étude approche l'oeuvre de Freud en ce qui concerne le champ de l'éducation, à partir de la position de Freud devant la cause psychanalytique et le champ de l'éducation. Et le concept fondamental de transfert qui se présente comme fondation de la pratique et de l'enseignement de l'expérience psychanalytique dans l'intension, l'extension et dans l'interlocution avec des autres champs se fait présente ayant aussi une place dans l'éducation. On approche le transfert, l'infantile, la sexualité, le complexe d'Oedipe, la dimension de l'énigme, la différence, la chute des idéaux, le savoir inconscient, l'enseignment, la transmission, la formation, l'impossibilité, en apportant le discours analytique comme un outil d'articulation de cet ensemble avec la croyance en la possibilité de travailler dans l'éducation à travers la construction du savoir. On soutien ici une croyance. On croit que l'interlocution entre la Psychanalyse et l'Éducation, entre les psychanalystes et les éducateurs, puisse être capable d'apporter des effets et de rendre possible des déplacements de discours. Nous n'attendons pas des réponses à toutes les questions, ni une conclusion pour mettre fin au débat. Les lacunes doivent être ouvertes en permettant le progrès et la présence permanente d'une demande par rapport à l'art d'enseigner 


\section{Agradecimentos}

Um trabalho que tem como motor o desejo é um trabalho solitário. E na solidão da escrita, nas tantas folhas em branco, nos pós de borracha (sou antiga quando se trata de escrever) ao ir recheando cadernos com palavras, palavras, palavras, pude constatar que ao assumir e sustentar sozinha esse trabalho, ele se fez, aconteceu, nasceu, cresceu, com a parceria de alguns outros.

Agradeço então aos parceiros que trilharam comigo esse caminho, às vezes silencioso, outras vezes bastante barulhento.

Existem várias formas de agradecer! Assim como existem várias formas de presentear! Aprendi isso muito recentemente com dois pequenos sujeitos que na sabedoria dos seus poucos 6 e 4 anos, me ensinam as coisas mais importantes da minha vida. Aprendi que não precisamos comprar nada para presentear, que o melhor presente é aquele que a gente constrói, especialmente para aquela pessoa especial. E que algumas vezes, podemos construir presentes para nós mesmos. E como isso é legal. Aprendi que ouvir a palavrinha mágica "obrigado" é melhor que ouvir "eu te amo", porque no "obrigado" está implicado esse "eu te amo" que a gente demanda tanto do outro. Aprendi que muitas vezes a palavra precisa ser silenciada e que agradecemos muito mais com um simples olhar, um abraço apertado, um sorriso ou mesmo uma lágrima. Agradecemos com o silêncio, mas também agradecemos com um poema, com uma canção, com um desejo, ou mesmo com um monte de rabiscos! Enquanto estou aqui, arrebatada pela angústia da escrita, escuto o barulhinho dos passos correndo de uma pessoinha que vem gritando, atrapalhando minha concentração: “Mamãe, posso te dar um beijo?” Quer agradecimento melhor?

Aprendi com eles, meus pequenos grandes mestres, que a maternidade é a maior aventura da vida. Que ela nos leva a lugares nunca antes imaginados, que ela nos faz ousar, arriscar, se jogar sem medo, inventar. E se a maternidade é a maior aventura da vida, a partir dela aprendi e venho aprendendo a cada dia, que educar é o maior desafio que a vida nos coloca. E aprendi que não há certezas nem garantias.

Agradeço ao Vicente, que com sua espontaneidade e suas grandes sacadas me ensinou, plagiando a gatinha do filme "Bolt - O super cão", que eu não precisava ficar triste com minhas dúvidas e embaraços. Que as crianças odiavam os adultos porque elas queriam ser adultos, isso é o complexo adultês!

Agradeço ao Guilherme, que com sua doçura e sua paz, me ensinou a dosar até onde ir, 
até onde segurar sua mão e que aos pouquinhos a mãe vai se tornando desnecessária. Dura, mas importantíssima, constatação.

Agradeço a esses dois pequenos por suportarem minhas ausências, minhas irritações, minhas bravezas, meu choro, minha impaciência. Agradeço por sempre me oferecerem seu beijo e por arrancarem de mim um sorriso, uma gargalhada, em meio a tanto tormento.

Agradeço ao Alex, meu maior e melhor parceiro, de todas as horas, que quis e veio comigo para o que der e vier, no dia branco, na noite escura, na primavera em flor. Parceiro na dança da vida e companheiro nessa grande aventura. Agradeço por dividir comigo o desafio de educar. Agradeço por sua paciência, seu carinho, seu colo, seu amor. Agradeço por se embaraçar comigo, por ser meu guia nos meus momentos obscuros e por me permitir guiá-lo em meio a sua escuridão. Obrigada por apostar comigo e me apoiar sempre.

Agradeço à Marilene e Roseli, anjos silenciosos nas mãos de quem deixei meus filhos nas tantas vezes que precisei me ausentar. Obrigada pelo compromisso que sempre tiveram com o trabalho, pela comida saborosa e cheirosa, pela casa limpa, pela roupa lavada, pelo lanche na mesa e, principalmente, pelo cuidado sempre zeloso com meus pequenos moleques.

Agradeço à Helenice Medeiros, minha querida Didi, simplesmente por fazer parte da minha vida, em todos os momentos. Embora não tenha sido a primeira, foi, é e sempre será a professora mais importante que já passou pela minha vida. Agradeço por sua posição decidida, por sua postura ética e por me transmitir, sem que eu me desse conta disso, o gosto pelo magistério.

Agradeço à Tia Tereza, Tia Deila, Tia Sônia, Tia Glória, mais uma vez à Dona Helenice, Dona Élvia, minhas inesquecíveis professoras da educação infantil e do ensino fundamental, com quem descobri as letras e os números, que me despertaram para maravilhosa aventura da leitura e da escrita. Que deixaram sua marca cravada na minha história, na minha memória e no meu coração. À Dona Aparecida, Aeysson, Dona Alcione, Sr. Gonzaga, Dona Gracinha, que me transmitiram muito mais do que análises sintáticas e uso da crase, funções matemáticas ou teoria dos conjuntos, latitudes e longitudes, feudalismo e o descobrimento do Brasil, as ciências e reprodução humana. Há algo deles no que sou hoje, nas escolhas que determinaram meu caminho.

Agradeço aos meus "amiguinhos" de infância, que se aventuraram comigo no desbravar desse universo cheio de mistérios e de magia. Alguns seguiram comigo nessa aventura por 14 
anos. Outros foram se perdendo pelo caminho, nos desencontros da vida. Mas essa mesma vida também promove encontros, reencontros. Agradeço também aos amigos que encontrei pelo meu caminho. Aos amigos que vieram depois da infância, mas que parecem que sempre estiveram ali e que fizeram parte dela. Aos amigos que depois de anos pude reencontrar, trazendo a infância de volta, mesmo que na lembrança.

Agradeço à Lê e à Pri, com quem sempre pude contar nos meus momentos de aperto e de sufoco. Meio sobrinhas, meio irmãs, sempre amigas, sempre queridas do meu coração.

Agradeço aos meus colegas de lida, de trabalho árduo, de estudo, de sustentação de um lugar para a formação do psicanalista. Meus colegas do Ato Freudiano, pelo entusiasmo.

Um obrigado sem palavras à minha mãe. Certamente nenhuma dessas linhas seria escrita sem a presença, a marca e o desejo dela. Assim como é sem palavras meu obrigado à minha mãe, é sem palavras minha dor e meu vazio por não poder brindar com meu pai o fim desse percurso. Um percurso, que como num corte, ao se fechar, abre uma nova possibilidade de trabalho. Para ele não havia importância nenhuma em receber o título de mestre, mas certamente se encheria de alegria pela conquista tão importante para mim. E depois de retomar a Acrópole, de escrever sobre esse ponto de real, deparo-me com o real da morte, da morte de meu pai, que vai embora, sai de cena quando ainda precisava tanto dele. Mas lhe agradeço por ter me deixado sua alegria, seu sorriso largo, sua presença marcante e firme. Herança sem preço que pude conquistar e fazêla minha.

Agradeço, por fim, de forma muito especial, à Ana Maria, por seu acolhimento, sua paciência, sua ética, seu compromisso, sua escuta. Obrigada por me permitir um trabalho próprio. Certamente não o melhor, o mais completo, o mais afinado. E sim um trabalho com lacunas, hiâncias, furos, mas decidido e certamente um trabalho meu, onde ao ler, me reconheço, onde pude, não sem a sua presença, colocar algo de meu. 
Sobre o início:

Uma introdução 


\begin{abstract}
"Quem quiser aprender nos livros o nobre jogo do xadrez não tardará em perceber que as aberturas e os finais podem ser objeto de uma exposição sistemática exaustiva das jogadas que se seguem à abertura. Somente o estudo diligente de partidas realizadas entre mestres de xadrez pode preencher esta lacuna. As regras que podemos assinalar para a prática do tratamento psicanalítico estão sujeitas a idêntica limitação." (FREUD, 1913, p. 247)
\end{abstract}

É dessa maneira que Freud dá início às recomendações aos médicos que exercem a psicanálise. E com essa indicação nos aponta, sem rodeios, que entre a jogada de abertura e o xeque-mate que encerra a partida, nesse percurso que precisa ser traçado, o que está em questão são a experiência e a invenção. É preciso que o analista invente aí sua prática. E sua prática se faz na experiência; na experiência própria e na de alguns outros.

É preciso um início, um pontapé inicial, uma jogada de abertura que dê partida a esse, e a todo, processo de experiência. É sempre uma pergunta quanto ao início, a origem, que abre o caminho, que lança a centelha para a estruturação e a construção de um saber. E o saber aqui é o saber da experiência.

Porém, Lacan (1969-70), também de forma tão precisa e pontual, afirma que "para estruturar corretamente um saber, é preciso renunciar à questão das origens" (p. 17). A origem remete ao ponto mítico, sem sentido, sem palavra, que precisa ser construído nas lacunas deixadas pela história. A esse ponto da origem só se chega, ou não se chega e somente se aproxima dele, depois de um longo e árduo trabalho. Depois de já ter sido dado o pontapé inicial, depois de já ter se emaranhado na teia de significantes, de ter retomado o fio e, quem sabe, somente ao chegar ao final, ao xeque-mate, onde restam poucos significantes nessa representação do sujeito. $\mathrm{O}$ início como origem aponta para o impossível. Mas o início que nos interessa é como lugar. Lugar de desejo que implica um ato.

É com o enigma sobre a origem que o sujeito infantil dá partida às suas investigações. Porém, é preciso se desvencilhar dessa busca, manter aberta a pergunta, seguir o circuito, para assim estruturar um saber.

E é assim, nesse jogo significante que esse ensaio tece seu percurso, onde o que está em questão não é alcançar a meta, oferecer respostas, possibilitar e facilitar a compreensão, mas sim cumprir seu trajeto, seu circuito, e sustentar a pergunta que lhe serve de causa. 
O leitor, educador ou não, psicanalista ou leigo, que, por ventura, percorrer as linhas do texto que aqui se segue, não precisa compreendê-lo. Porém, se a partir dessa leitura, uma pergunta for lançada, uma inquietação lhe acossar ou mesmo ficar com uma pulga atrás da orelha, podemos dizer que o este texto cumpriu sua função.

E é assim, sem esperanças, ilusões, pretensões ou ideais, que é possível percorrer a trilha dos significantes lançados nesse texto. Não há aqui nenhum objetivo de que se chegue ao final com uma conclusão ou uma resposta que possa fechar a questão. O que nos interessa aqui é seguir o trajeto, percorrer o circuito traçado, fazer valer a experiência e permitir, que a partir daqui novas perguntas possam ser lançadas.

A pergunta que dá origem a essa investigação "o que pode um psicanalista na psicanálise em extensão, na interlocução com outros campos de saber, na interlocução com a educação?", vai se desdobrando, abrindo novas perguntas, que permitem pontos de amarração que tecem o laço entre psicanálise e educação. Tal pergunta salta aos ouvidos e é somente a partir de um encontro singular com a Psicanálise que esse reencontro com a Educação se faz possível nesse percurso. A Educação entra aí, na cadeia, como mais um significante na série, a ser trabalhado, burilado, lapidado. Este é o percurso trilhado no primeiro ensaio dessa dissertação, um ensaio introdutório, que traz as bases que sustentam esse estudo. Bases que apontam a linha tênue que liga a Psicanálise à Educação, trazendo também esta como uma arte, uma prática e não uma ciência. Sendo assim, é a psicanálise, o texto psicanalítico, seu discurso e significantes que nos servem aqui como esteio. É a partir deles e com eles que vamos até ao campo da educação nessa interlocução. São os textos de Freud e Lacan, fundamentalmente, assim como de autores, psicanalistas, contemporâneos, que aqui nos servem de guia e nos dão a direção desse percurso.

Ao reinventar sua arte de educar, dando um passo daquilo que é ideal, satisfatório, adequado, metódico, para privilegiar o que há do seu estilo no seu ato, o educador é convidado, no segundo ensaio, a se atentar para um outro ponto de fundamental importância no ato de seu ensino, a transferência. Neste segundo ensaio, o conceito fundamental da transferência dá a direção. A psicanálise recolhe esse fenômeno das relações em geral e faz dele seu instrumento, sua prática. A psicanálise é uma prática da transferência. A partir daí, fazemos um breve passeio pela história da psicanálise e pelo fenômeno da transferência, para falarmos também desse fenômeno naquilo que toca ao 
campo da educação e à interlocução com a psicanálise, onde nos deparamos com a transferência de trabalho, ao texto, aos significantes. Aqui trazemos a aposta de que o educador possa também seguir a precisa indicação que Freud deixa aos analistas, de que estes precisam encarar as coisas de um ponto de vista diferente. E sendo assim, o que está em questão nesse ensaio é a posição do educador frente ao ato de educar.

Ao dar lugar à transferência na sua prática, fica a aposta de que o educador possa acolher a demanda de ensino que lhe é dirigida e, a partir daí, sem respondê-la, sustentar uma pergunta, permitindo assim que um saber seja construído.

Dessa forma, damos um passo em direção ao terceiro ensaio dessa dissertação, trazendo aquilo que a psicanálise revela de inédito em seu discurso e a subversão quanto à sexualidade no despertar do desejo de saber. Percorremos o complexo de Édipo na medida em que este é, como nos aponta Catherine Millot (2001, p. 78), "a pedra de toque do empreendimento educativo", assim como passamos pelas teorias sexuais infantis, com as quais o sujeito infantil dá partida às suas investigações, colocando a "pulsão de saber" a serviço de suas energias intelectuais. Ao sustentar a dimensão do enigma, torna-se possível a construção do saber. Neste ensaio, também nos deteremos no saber que interessa ao campo psicanalítico, o saber inconsciente. Mais uma vez o que está em questão aqui é a posição do educador diante do ato de educar, ao sustentar sua função. Assim como, mais uma vez, faz-se aqui uma aposta de que o atravessamento pelo discurso psicanalítico, pelos significantes da psicanálise, possa produzir efeitos na posição do educador.

A pergunta que dá partida a essa investigação se desdobra na questão que, de fato, se coloca como motriz de todo esse percurso. O que a psicanálise, ou o discurso psicanalítico, traz de implicações ao campo educacional, mais precisamente à formação e a posição do educador? Esta é a questão que serve de eixo, de guia e que dá a direção desse trabalho. E é com ela que avançamos para o quarto e último capítulo dessa dissertação. Neste ensaio abordamos os significantes ensino, transmissão e formação. Significantes que se articulam, se enodam e que, ao mesmo tempo apontam uma conjunção e uma separação no percurso da formação do analista. É Lacan quem dá um passo com relação à formação do analista e a transmissão da psicanálise a partir do conceito de "Escola", ao subverter os significantes "ensino" e "mestre", tão caros na formação, subvertendo também esta última, situando-a no campo da experiência. Lacan, a partir de seu retorno ao texto freudiano, 
aponta os desvios e recoloca a psicanálise nos trilhos, retomando seus fundamentos e dando um passo naquilo que se refere à formação do analista.

Neste ensaio, também abordamos brevemente os quatro discursos trabalhados por Lacan a partir daquilo que este novo discurso, o psicanalítico, pode instituir, fazendo uma outra leitura dos demais discursos que já estavam aí, presentes na cultura. São breves as colocações que fazemos aqui neste ensaio sobre os quatro discursos, porém pontuais. Pois aqui podemos precisar esse atravessamento pelo discurso psicanalítico que perpassa todo o texto, todo esse percurso trilhado.

E assim chegamos ao final. Como nos indica Lacan, na entrada já está dada a saída, quanto ao percurso de uma análise. Aqui também, na partida, na questão que abre a possibilidade desse percurso de trabalho, que marca sua entrada na cadeia significante, já está dado seu fim, sua saída. E assim, concluímos que ao final nos resta uma aposta. Uma interlocução entre psicanálise e educação só se dará por essa via, sem garantias e promessas, mas sim fazendo uma aposta no efeito desse atravessamento pelo discurso psicanalítico e na subversão que ele comporta. 
De um encontro singular com a Psicanálise a um reencontro com a Educação 


\section{Saiba}

(Arnaldo Antunes)

Saiba: todo mundo foi neném

Einstein, Freud e Platão também

Hitler, Bush e Saddam Hussein

Quem tem grana e quem não tem

Saiba: Todo mundo teve infância

Maomé já foi criança

Arquimedes, Buda Galileu

E também você e eu

Saiba: Todo mundo teve medo

Mesmo que seja segredo

Nietzsche e Simone de Beauvoir

Fernandinho Beira-Mar

Saiba: Todo mundo vai morrer

Presidente, general ou rei

Anglo-saxão ou mulçumano

Todo e qualquer ser humano

Saiba: Todo mundo teve pai

Quem já foi e quem ainda vai

Lao-Tsé, Moisés, Ramsés, Pelé

Gandhi, Mike Tyson, Salomé

Saiba: Todo mundo teve mãe

Índios, africanos e alemães

Nero, Che Guevara, Pinochet

E também eu e você. 
Em carta à Wilhelm Fliess, em 26 de janeiro de 1900, Freud escreve que está "reunindo o material para a teoria sexual, esperando que uma centelha possa inflamar o que já foi acumulado" (Freud, 2007, p. 13).

É nesta mesma posição, à espera de que uma centelha possa inflamar tudo o que foi acumulado através das leituras feitas, que me coloco a escrever. Esta centelha freudiana é o que impulsiona e inspira esse projeto de pesquisa e faz da determinação e da persistência o veículo para atravessar este trabalho de escrita.

Diante de suas questões e inquietações, dos impasses, dos embaraços e dos avanços, Freud se debruçava sobre o papel, de caneta em punho e se colocava a escrever. Assim, escreveu toda uma obra. Tal escrita, porém, "não se trata de um simples escrever, era um escrever que articulava real e simbólico” (Lopes \& Peres, 2007, p. 15). E sua obra é assim, articula real e simbólico ${ }^{1}$, lança centelhas, abre possibilidades de leituras, deixa lacunas que permitem a escrita de outros textos, convoca-nos ao trabalho, à produção, a construir um percurso próprio. Dessa forma, a obra freudiana, sua invenção, faz-se atual, pois deixou suas marcas, instaurou algo inédito na cultura e continua operando na leitura do sujeito e suas relações.

Michel Foucault, ao trabalhar os hypomnemata ${ }^{2}$, em seu texto "A escrita de si", traz uma citação de Sêneca, da qual podemos recolher um trecho para ilustrar com precisão este laborioso trabalho de escrita.

\footnotetext{
"A passar sem descanso de livro para livro, sem nunca parar, sem voltar de tempos em tempos ao cortiço com a nossa provisão de néctar, sem tomar notas, por consequência, nem nos dotarmos por escrito de um
}

\footnotetext{
${ }^{1}$ Real, Simbólico e Imaginário - termos apresentados por Jacques Lacan para definir essas três instâncias amarradas borromeanamente. Essa amarração borromeana traz para o centro da obra lacaniana as questões da topologia. Lacan dedica um Seminário, intitulado R. S. I., de 1973, ao estudo e à elaboração dessas instâncias e da topologia. Real não é o mesmo que realidade. Uma das definições dadas por Lacan é situando o real no estatuto do impossível. A realidade estaria mais ligada à categoria do imaginário fantasístico. O simbólico refere-se à cadeia significante e às concepções da linguística utilizadas e subvertidas por Lacan.

"Cada um desses domínios constitui-se efetivamente em categoria na medida em que encontrou seu fundamento na estrutura originária do aparelho psíquico: o imaginário na organização do estádio do espelho, o simbólico na cadeia significante, o real na impossibilidade (lógica) da relação sexual." (KAUFMANN, 1996, p. 474)

${ }^{2}$ Hypomnemata - "constituíam uma memória material das coisas lidas, ouvidas ou pensadas; ofereciam-nas assim, qual tesouro acumulado, à releitura e à meditação ulterior. (...) a escrita dos hypomnemata é um veículo importante da subjetivação do discurso. (...) trata-se, não de perseguir o indizível, não de revelar o que está oculto, mas, pelo contrário, de captar o já dito; reunir aquilo que se pôde ouvir ou ler, e isto com uma finalidade que não é nada menos que a constituição de si." (FOUCAULT, 1992, p. 137)
} 
tesouro de leitura, sujeitamos-nos a não reter nada, a dispersarmo-nos por diferentes pensamentos e a esquecermo-nos a nós próprios (Foucault, 1992, p. 139).

A invenção freudiana do conceito de inconsciente faz um corte na história da razão, abrindo, como um rasgão na cultura, a terceira ferida narcísica da humanidade, colocando o homem fora do centro, não mais senhor em sua própria casa. "Depois de Freud não se pode mais fazer filosofia como antes", afirma-nos Émile Noël, no prefácio do livro de François Châtelet. "O conceito de inconsciente é uma contribuição incontornável da psicanálise para a filosofia, que não pode mais considerar o pensamento "puro" cortado do afeto..." (CHÂTELET, 1994, p. 14). Se a escrita instaurada por Freud não é uma escrita qualquer, simples, pois articula real e simbólico, esta escrita só se faz levando-se em conta o texto e o sujeito do inconsciente, assim como seu percurso.

Sendo assim, a escrita deste trabalho tem a função de recolher os restos de um minucioso trabalho de leitura, extrair os efeitos da luz lançada nestes diversos textos percorridos e, enfim, decantar em letras aquilo que pode ser transmitido, produzindo um texto próprio.

Para dar partida a esse trabalho não posso me abster de falar daquilo que me inquieta e me impele a esse labor, a saber, meu encontro com a psicanálise. Por que a psicanálise?

Ainda no curso de Magistério, fui apresentada, de forma breve, a alguns conceitos psicanalíticos, à invenção freudiana, e fui tomada pelo desejo de cursar psicologia, ainda sem saber muito bem do que se tratava tal desejo. Na graduação, às voltas com o trabalho para conclusão de curso no qual abordei questões relativas à função paterna e à inscrição da lei, deparei-me com o texto freudiano "Uma perturbação de lembrança na Acrópole" (1936). Freud, já doente, "meio velho, precisado de indulgência e sem poder mais viajar" (p.), endereça esta carta/letra à Romain Rolland pelo seu septuagésimo aniversário. A maneira como fui afetada por este escrito determinou meu percurso pela psicanálise, pois foi fundamental para que uma verdadeira demanda de análise fosse feita e para que fosse dada a partida da experiência na carne da convicção do inconsciente.

Nesta carta, Freud relata ao amigo escritor a experiência vivenciada 32 anos antes quando do seu singular encontro com a Acrópole. Neste intervalo de uma geração, constrói 
toda sua teoria, inscreve a psicanálise na cultura e elabora seu desejo frente à causa psicanalítica.

Freud e seu irmão, dez anos mais moço, costumavam viajar de férias sempre a Roma, mas em função de um compromisso de trabalho do irmão, tiveram que alterar o destino da viagem para Trieste. Em Trieste, um amigo sugeriu que fossem a Atenas, já que estavam tão perto. Tal possibilidade, de visitar Atenas, foi imediatamente negada pelos irmãos. Seria impossível, muito difícil viajar até Atenas. Durante todo o dia, até a hora da partida do trem que os levaria a Atenas, vagaram pela cidade de Trieste, sem falar um com o outro sobre a sugestão do amigo. Freud, tomado por um pessimismo e certa timidez, dirigiu-se, juntamente com o irmão, à estação e seguiram, sem palavras, até Atenas. Já em Atenas, diante da Acrópole, o notável pensamento: "Então efetivamente existe tudo isso que aprendemos na escola?!" (Freud, 1989, p. 13). É afetado por um "sentimento de estranheza", que surge frente ao silêncio e à ausência de palavras de que é acometido. Há ali uma "topada com o real", com aquilo que aponta para algo da ordem do impossível, como se não pudesse "chegar tão longe", ver com os próprios olhos aquilo que foi tão desejado e parecia tão distante nos tempos de colégio, como se não pudesse realizar mais do que o pai realizou.

Freud coloca a público seu percurso e seu atravessamento pela convicção do inconsciente. Discorre nesta carta sobre a ética e o desejo, a castração, o impossível, a novidade, a interdição que barra e divide o sujeito, inscrevendo-lhe a falta e abrindo-lhe a possibilidade para todo o resto. Trabalha ainda a resposta do sujeito, que é constitucional, dada pela estrutura, diante dessa "topada com o real" da falta, da divisão, inscrevendo um movimento entre a crença e a não-crença, num jogo da estrutura com o vaivém entre o desmentido $^{3}$ e o reconhecimento da falta, "como se ainda fosse sempre não permitido,

\footnotetext{
${ }^{3}$ Desmentido - tradução do termo alemão verlungnung. "A noção de desmentido assume seu pleno sentido, na medida em que é articulado com a castração. O desmentido dirá respeito ao não-reconhecimento da diferença sexual, isto é, da ausência de pênis na mulher." (KAUFMANN, 1996, p. 447) Freud trabalha este termo nos artigos "Fetichismo" (1927) e "A cisão do eu no processo de defesa" (1938). Trata-se de uma nãocrença na diferença. Freud vai falar do desmentido (verlungnung) como sendo o mecanismo por excelência da perversão, tomando o fetiche como exemplo clássico da estrutura perversa. Porém, no seu trabalho sobre " $A$ cisão do eu no processo de defesa" e nos textos nos quais versa sobre a sexualidade infantil, Freud vai articular o mecanismo do desmentido como estrutural, do qual nenhum ser falante escapa. "Nessa medida, por estar articulado com a castração, o desmentido se oferece como uma placa giratória entre neurose, psicose e perversão." (KAUFMANN, 1996, p. 447)
} 
querer superar o pai” (Freud, 1989, p. 25).

A estranheza, a não-crença como uma tentativa de recusar um pedaço da realidade, o impossível de se chegar tão longe, a dúvida de que "algum dia chegaria a ver Atenas", apontam para esse movimento da estrutura, que somente frente a estes estilhaços do real adquire "também uma convicção "que se estende ao inconsciente"” (Freud, 1989, p. 15), ou seja, que se inscreve de fato no inconsciente, como significante da castração. É neste ato, diante do real da castração, do impossível, que se instaura o inconsciente, fundando, constituindo e marcando o sujeito como dividido.

Revisitar essa carta, esse encontro de Freud com o impossível da castração, remeteme a uma revisitação ao meu percurso e me faz checar meu desejo frente à causa psicanalítica. Esse encontro singular com a Acrópole, o marco da origem da cultura ocidental, possibilita a Freud construir toda uma obra e no só-depois elaborar esse ponto sem palavras.

No decorrer de meu percurso pela psicanálise, na intensão e na extensão ${ }^{4}$, ou seja, na minha travessia analítica e no trabalho na formação, recorro sempre a esse texto de Freud que ainda me afeta como se o estivesse encontrando pela primeira vez. Talvez ainda precise avançar e caminhar no meu percurso para que possa colocar em palavras esse "sentimento de estranheza" que me afeta a partir dessa leitura.

A Acrópole, para Freud, aponta para esse “chegar tão longe”, esse impossível, esse encontro com o real. É um realizar mais do que o pai realizou. Porém, cada um de nós tem nossas “Acrópoles”, nossos desejos mais íntimos, que nos causam a persistir.

E onde entra a educação?

Desse singular encontro com a psicanálise, nessa dobradiça entre intensão e extensão, em minha formação como analista, fui causada, diante do real da clínica, a trabalhar questões sobre a lei e o desejo, a ética da psicanálise, o pai, a transmissão, a castração. E novamente me deparo com a "Acrópole", com minha "Acrópole", e diante do

\footnotetext{
${ }^{4}$ Intensão e Extensão - termos forjados por Lacan ao avançar na questão da formação do analista. A intensão refere-se à prática clínica articulada à análise pessoal, ou seja, na experiência da travessia analítica e na direção da cura. A extensão é o que se refere à formação do analista e ao ensino e transmissão da psicanálise, tomando o laço social entre analistas como fundamental, assim como a incidência da psicanálise na cultura, na interlocução com outros campos de saber.
} 
real da maternidade me reencontro com a educação.

Minha prática clínica, no trabalho com crianças, pais, professores, na escuta dos sintomas infantis, "diagnosticados" pela escola, do embaraço dos pais, da busca incessante dos professores por métodos e técnicas que lhes dê garantias de um ensino satisfatório e pleno e, principalmente, da escuta e elaboração dos meus embaraços diante da convocação ao ato de educar, sou surpreendida mais uma vez pelo texto freudiano, pelo rigor dos conceitos e pelo lugar da educação, que vem como um novo significante nesta série do meu percurso de trabalho, marcando um passo preciso na minha formação. Lei, desejo, pai, ética, transmissão, formação, castração, educação. Como educar? Mas, educar não se ensina.

Tomemos o cuidado para não cairmos no universalismo dessa afirmação. A educação é um campo milenar que traz na sua prática, desde os tempos mais remotos, o ensino. Todavia, educar não se ensina no sentido de se buscar um manual, um passo a passo garantidor de um bom resultado ao final. Não podemos negar o ensino. Ensinam-se conteúdos, conhecimentos matemáticos, regras gramaticais, longitudes e latitudes dos países espalhados pelo mundo. Ensinam-se fatos históricos, ensinam-se bons modos. Não se trata de negar todo esse saber livresco, referencial, esse arcabouço cultural no qual estamos imersos e submetidos. É inegável que há ensino. Mas, ensina-se como educar? A afirmação de que educar não se ensina também nos coloca diante dos conhecimentos acumulados pela pedagogia, coloca-nos diante de tanto trabalho no sentido de ensinar a ensinar, no sentido de garantir um "bom professor" e um "bom aluno", ou seja, uma educação plena de satisfação. Porém, não é com isso que nos deparamos no dia-a-dia, nos consultórios, nos corredores das escolas. Deparamo-nos com a falta de garantias, com o que escapa a esse ensino, com o efeito pontual de uma intervenção e não com um sucesso pleno da aplicação de uma técnica.

A questão está então no efeito de transmissão de um ensino. A questão não está em ensinar a ensinar, mas talvez em aprender a aprender aquilo que pode ser transmitido. "O melhor 'técnico', é aquele que conserva sua disponibilidade diante do que ele tem pela frente, sempre o particular, (...) e que aprende cada dia algo de novo" (SAFOUAN, 1985, p. $50)$. 
Dessa forma, é imprescindível precisar a junção e disjunção desses termos, ensino e transmissão, para pensarmos a educação como ensino e/ou transmissão, como será trabalhado no quarto ensaio dessa dissertação.

A educação faz parte da minha história. Mãe, tia, tia-avó, professoras. Professoras que trilharam um percurso reconhecido, respeitado e fizeram da educação, do magistério, um dom. Por que não também seguir este caminho? Desde pequenina, as brincadeiras de escolinha tomavam conta do dia-a-dia. Dei partida à minha vida profissional também na educação fundamental, porém tinha algo ali que me inquietava e que não sustentava essa escolha. O desejo vacilava, não estava decidido. Mas essa história, essas relações, essas pequenas experiências deixaram suas marcas. Marcas significantes, que insistem, e um desejo latente que começa a ganhar voz e a ser lapidado.

A educação está para todos. Não digo isto no sentido da demanda por uma escola única, universal, da educação igualitária, para todos. Não se trata aqui das lutas políticas e sociais para que todos tenham direito à educação, à cidadania. Tais políticas públicas são pertinentes e têm sua função, porém não é isso que nos interessa aqui. O que nos interessa é a função, o lugar da educação na economia psíquica do sujeito, determinante na sua constituição. A educação a que nos referimos aqui não é unicamente a educação formal, institucionalizada pelo modelo moderno de escola. A educação está para além dos muros da escola e o ato de educar é convocado a todos aqueles que lidam com a infância e o infantil. Educar é função. Função que se faz em ato. Educar está para além de "ensinar, instruir ou promover o desenvolvimento da capacidade intelectual, moral e física de alguém” (FERREIRA, 2000, p. 251). Em alemão, língua do texto psicanalítico que nos serve de base, a palavra erziehung, traduzida como education, tem um significado mais amplo, referindo-se à “criação", no sentido genérico do termo. Para nós, educar também abarca a amplitude do termo criar e aquele que cria, que educa, inscreve algo novo e transmite um legado.

Tal afirmação, de que a educação está para todos, também pode soar perigosa, universalista e contradizer a lógica do particular na qual se sustenta o discurso psicanalítico. Porém, se estamos inseridos num universo cultural, se vivemos numa sociedade civilizada, estamos submetidos à educação. A educação é algo que está na cultura e, sendo assim, está 
submetido às leis da linguagem, ao simbólico e está para todos.

Freud nos aponta em “Totem e Tabu” (1913) que a cultura, a civilização, funda-se na interdição do gozo. Há uma proibição primeira, há uma interdição que barra o gozo pleno, mas abre a possibilidade para o avanço na civilização, no laço social. A instauração da cultura se dá por essa interdição universal, a interdição do incesto, pela inscrição dessa lei simbólica que está para todos.

Neste texto, Freud enuncia o mito moderno do assassinato do pai primevo, demarcando a entrada do homem no campo da cultura a partir da incidência da lei. Lei que faz barra, lei do pai que interdita o desejo incestuoso, que interdita o gozo materno, lei que instaura a civilização, lei que não é outra senão a lei simbólica, lei da linguagem. Neste mito, é possível ler os dois mandamentos primordiais do totemismo, ou seja, a proibição de matar o totem e o de esposar uma mulher que pertença ao mesmo totem, ao mesmo clã. A partir dos mandamentos do totem, Freud discorre sobre os tabus associados a eles e aponta o tabu do incesto como a proibição universal, interdição fundamental, que marca a entrada do homem na civilização. Faz um paralelo desse mito constitucional, estruturante, da cultura, com o mito edípico, constitucional do sujeito, mito individual do sujeito neurótico. Os dois mandamentos/tabus coincidem com os crimes cometidos por Édipo, assassinar o pai e desposar a mãe. Este mito grego foi tomado por Freud para descrever o destino inexorável de todos os homens, apontando a estrutura e o núcleo da neurose a partir dos dois desejos infantis, ou seja, eliminar o pai e ter a mãe só para si. O mito edípico está para o sujeito assim como o mito do assassinato do pai está para a cultura, como operador da estrutura e instaurador do recalque.

O complexo de Édipo, operador estrutural, instaurador do recalque e complexo nuclear da neurose, é apontado por Catherine Millot como sendo "a pedra de toque do empreendimento educativo". (2001, p. 78) Pois é o educador quem favorece o acesso da criança à humanidade, quem lhe abre a possibilidade para a ordem simbólica, quem lhe oferece a chave para seu desejo.

A leitura que Freud nos oferece da tarefa primeira da educação é a contenção das pulsões que, ao seguir seu circuito, na sua gramática, exige um dique que barre o excesso de gozo. O mecanismo do recalque como instaurador da interdição da lei, da renúncia, 
assim como das práticas educativas, constitui o fundamento da civilização. Posteriormente, no seu avançar teórico/prático sobre o complexo de Castração e as pulsões e seus destinos, Freud vai falar não mais de uma contenção das pulsões, mas sim da exigência de uma renúncia à satisfação pulsional para que o homem possa estar na civilização.

Numa mirada desavisada, podemos pensar que psicanálise e educação são campos distintos, que nada têm em comum e que a aproximação entre eles não traria nada de novo. Podemos cair no engano de acreditar que a psicanálise se refere ao tratamento das afecções nervosas, das emoções ou do desenvolvimento afetivo, e fazer uma aproximação forçada desse campo com a psicologia. Maria Cristina Kupfer (2007) nos aponta que essa “aproximação é talvez mais problemática do que aquela entre educação e psicanálise” (p. 23). Isso porque a psicologia está baseada em princípios científicos e foca seus estudos na observação e introspecção. E ao escolher o comportamento humano como seu objeto, a psicologia se coloca bastante adequada ao método da ciência positivista, colocando-se bem próxima do ideal científico de objetividade, sendo passível de experimentação e adequação. O sujeito que está em questão na psicologia é o sujeito do comportamento, da consciência. Por isso a grande dificuldade de aproximação entre psicologia e psicanálise, pois o sujeito da psicanálise, sujeito do inconsciente, está na contramão da adequação, da experimentação, da objetividade. É sujeito que deseja.

O livro de Catherine Millot, "Freud Antipedagogo", continua atual em alguns aspectos, porém há outros pontos de sua tese onde foi possível acrescentar novas perguntas e avançar, a partir de estudos posteriores como os de Maria Cristina Kupfer e Leandro de Lajonquière. Esses dois autores são pioneiros, no Brasil, a trabalhar essa articulação entre psicanálise e educação. Recorrem ao texto de Millot, mas dão um passo além, sustentando essa articulação e apontando que a psicanálise tem muito mais a contribuir com a educação que unicamente pelo trabalho com crianças em idade pré-escolar ou com problemas mentais graves que exigem um trabalho especial. E este foi o trabalho de August Aichhorn, pedagogo e contemporâneo de Freud, quem primeiro utilizou a teoria psicanalítica na sua prática pedagógica com jovens delinqüentes, possibilitando que novas reflexões fossem feitas a partir dessa interlocução.

A psicanálise pode trazer implicações para a educação de forma geral, a partir de 
seu discurso, que privilegia a ética e o desejo. É tomando a ética da psicanálise, ética que não está pautada no bem, mas sim no desejo do sujeito, e a torção provocada pelo discurso psicanalítico com relação ao saber, que essa implicação pode se dar. É isso que podemos ler em Freud, já em 1925, ratificado por Millot, Kupfer e praticamente todos os autores que se debruçam sobre o estudo dessa interface, ou seja, que a psicanálise tem a contribuir não para a teoria da educação, mas sim para a condição daqueles que estão na função de educar.

Kupfer trabalha brilhantemente esta aproximação, retomando as posições de Catherine Millot, ratificando que não se refere ao ponto de vista teórico-epistemológico. Não é possível pensar nessa articulação tomando como "educação" o que se produziu e se produz de teorias pedagógicas. É preciso fazer uma disjunção da educação/pedagogia, e tomar a educação neste sentido genérico, como apontado anteriormente, na sua incidência na cultura. Cultura e educação se instauram num mesmo golpe, a partir de um mesmo ato, e caminham pari passu.

Catherine Millot (1979) trabalha esta leitura insustentável da articulação da psicanálise com a educação, baseando-se nas disciplinas pedagógicas, na proposta de uma pedagogia analiticamente orientada ou de uma educação analítica. As respostas negativas às questões colocadas por Millot, pautando-se nesta premissa, foram retomadas por Kupfer, que nos aponta a importância de deixarmos de fora, nesta articulação, a pedagogia. É preciso deixar de fora a pedagogia, mas sem prescindir dela. A pedagogia, como ciência da educação, precisa ficar de fora, pois nessa leitura, atravessada pelo discurso psicanalítico, o significante educação é lido como prática, que implica um ato, uma decisão. Dessa forma, não entram em discussão métodos, técnicas, processos, motivações, currículos, mas sim o desejo. O desejo daquele que está na função de educador, de ensinante, de transmissor, e daquele que está na posição de aprendiz. Educa-se para além da pedagogia, educa-se menos pela teoria e mais com o que se é. Sendo assim, "não é necessário um saber teórico sobre o que se faz para ser um bom educador" (MILLOT, 2001, p. 148).

Este é um ponto fundamental do avanço nessa discussão a partir dos trabalhos de Kupfer. Millot para aqui, na negativa de uma pedagogia psicanaliticamente orientada. Kupfer vai com Millot além de Millot. Ratifica sua afirmação, mas aponta que as implicações desses campos estão para além da pedagogia, da técnica e tem como esteio a 
posição do educador.

A psicanálise também recolhe da educação contribuições para seu avanço. A educação, campo milenar da cultura, imprescindível para o avanço da civilização e que se funda na linguagem, traz novas roupagens e adereços para a estrutura, assim como novos lemas, guerras, sintomas, que podem ser recolhidos e lidos pela psicanálise, sempre à luz da estrutura, permitindo o avanço dessa teoria.

Assim, a estrutura está posta e o que aparece com o progresso científico e tecnológico, com o novo imperativo da contemporaneidade do apagamento da diferença, do discurso capitalista de mãos dadas com o discurso científico, com a mercantilização do saber, dos sintomas, dos desejos, são novas roupagens, novos adereços, novos sintomas, novos diagnósticos para a velha estrutura, que insiste em se fazer escutar.

Não é possível denegar, ou mesmo desmentir o progresso, porém não se trata de criar uma nova psicanálise, nem adequá-la aos modismos do momento, mas sim poder ler tais "progressos" da civilização à luz de seus fundamentos, de seu discurso.

No prefácio ao livro de Aichhorn, Freud nos alerta quanto à proximidade e a distinção desses dois campos. Fala da educação como "algo sui generis" (p.308) que não pode e, acrescento, não deve, ser substituído pela experiência psicanalítica.

É justamente neste ponto que se ancoram minhas inquietações e que se torna necessária uma leitura atenta do texto freudiano naquilo que toca à educação. Nesta leitura atenta, não podemos nos furtar de recorrer ao passo dado por Lacan a partir de seu retorno à obra freudiana. O texto lacaniano se oferece como um facilitador neste retorno à obra freudiana, principalmente no que se refere aos desvios e equívocos a que está sujeita tal leitura. A única maneira que vislumbro a articulação entre psicanálise e educação é pela via do discurso, ou seja, pelo atravessamento do discurso psicanalítico, pela ética que ele comporta, ética que privilegia o desejo e inscreve algo novo, tanto na cultura quanto para cada sujeito. E o que seria então esse atravessamento pelo discurso psicanalítico? Tomando o que um dos dicionários de nossa língua nos dá de significado para atravessar, o discurso analítico seria posto ao través, passaria através do campo educacional, fazendo um corte, um furo, produzindo efeitos. Atravessar, perpassar, ir de um ponto ao outro, sem se instalar no campo educacional como uma nova possibilidade de solução dos problemas, como uma 
nova tábua de salvação. E ao atravessar, fazendo um corte, no campo educacional, o discurso psicanalítico pode produzir efeitos, trazer uma nova pergunta que possa abalar as certezas que permeio esse campo.

Michel Foucault, em seu livro "O que é um autor", atravessado pelo ensino de Lacan na efervescência cultural dos idos de 1968 a 70, e principalmente, a partir de sua leitura atenta da obra freudiana, situa essa obra, juntamente com o texto marxista, como fundadora de discursividade. Tais autores são "instauradores de discursividade" porque "produziram alguma coisa mais: a possibilidade e a regra de formação de outros textos" (FOUCAULT, 1992, p. 58). São obras que possibilitam analogias, mas também permitem certo número de diferenças. As lacunas deixadas no texto freudiano permitem que um outro texto seja escrito, porém um texto atravessado pelo discurso psicanalítico, submetido a seus significantes. Na instauração de um discurso, obra e autor estão enlaçados e "é por isso, porque se trata do texto de um autor, que é preciso regressar de novo a ele" (FOUCAULT, 1992, p. 66).

É Lacan, no seu retorno aos fundamentos e significantes do texto freudiano, que inscreve a psicanálise em termos de discurso, ao afirmá-la uma prática discursiva. Este retorno, que se difere da redescoberta ou da reatualização, trata-se de um regressar ao texto, possibilitando um avanço que implica uma torção e que nos surpreende com o frescor da atualidade da obra freudiana. O discurso promove o laço social, sustenta as relações e a experiência analítica, que se trata de uma experiência de discurso, articulando assim o desejo ao laço social.

Tratarei mais detalhadamente sobre esse ponto no quarto ensaio, que tem como título "Educação: Ensino e/ou Transmissão? Os giros discursivos e a formação", no qual será trabalhada a incidência do discurso do analista no mundo, suas consequências para o sujeito, para a comunidade de analistas e para a cultura; assim como a importância da leitura que a psicanálise pode fazer, a partir de seu discurso, dos acontecimentos da cultura e do lugar do gozo na sociedade contemporânea.

É neste sentido que vejo a possibilidade de poderem também avançar a cultura e seus inúmeros campos a partir do que se pode beber do discurso psicanalítico. 
Utilizo a palavra avançar em vários pontos do texto, referindo-se ao efeito da intervenção do discurso psicanalítico em outros campos de saber e, mais precisamente, ao campo da educação. É necessário precisar com mais rigor esse significante, avançar, tomado a partir do discurso psicanalítico. Avançar, aqui, não tem o mesmo sentido de progresso ou desenvolvimento. Assim como também não se refere a "avançar o sinal", passar do limite. Tomemos avançar a partir da leitura psicanalítica, como algo que possibilita uma torção a partir do questionamento dos simples hábitos. Avanço no sentido de portar uma novidade, de dar um passo em relação ao desejo, desvencilhando-se do sintoma que fixa e amarra o sujeito num mesmo lugar.

Freud não acreditava na ideia de progresso tal como o século XIX a estabeleceu. O progresso científico e cumulativo, idealizado como aquilo que pode promover uma transformação, é incompatível para Freud com aquilo que está na essência do sujeito, a saber, a pulsão e o desejo, que se estendem à cultura. $\mathrm{O}$ progresso implica um ganho, um acúmulo. Em nome do progresso, cometeram-se as maiores atrocidades... O avanço, ao contrário, implica uma perda, a perda de gozo ${ }^{5}$.

A partir de um olhar mais atento e uma escuta mais apurada, percebemos que os campos psicanalítico e educacional têm uma implicação, ou seja, têm uma aproximação, e que podem trazer contribuições um para o outro. A psicanálise interessa à cultura e faz sua inscrição nesta. Sendo assim, atravessa, perpassa não só a educação como também outros campos do saber. À sua luz se faz leituras dos mais diversos fenômenos (culturais, sociais, políticos, educacionais, artísticos, religiosos). Tal leitura é feita a partir dos significantes e do discurso que lhe dá fundamento, como Freud nos mostra em seus textos de cunho mais social, tais como "Psicologia das massas e análise do eu" (1921), "O futuro de uma ilusão" (1927), "Mal-estar na cultura" (1930), "Por que a guerra?" (1933), "Sobre a transitoriedade" (1915), para citar alguns. Esses textos trazem essa vertente mais social de

\footnotetext{
${ }^{5}$ Gozo é um conceito forjado por Lacan, porém que tem sua base no texto freudiano a partir de suas elaborações sobre a pulsão e o mais além do princípio do prazer. Quando, ainda em seus primeiros artigos e casos clínicos Freud fala de um prazer na dor, de um cansaço doloroso, já está aí, aquilo que Lacan vai posteriormente chamar de gozo. "O que pertence ao gozo não é de modo algum redutível a um naturalismo, trata-se, ao contrário, do ponto em que o vivo pactua com a linguagem” (KAUFMANN, 1996, p. 221) O gozo está articulado ao saber. "O saber é o preço da renúncia ao gozo" (idem). E a neurose vai interrogar essa fronteira entre saber e gozo. Para se aceder ao saber inconsciente é preciso que haja uma renúncia ao gozo e sendo assim, o trabalho analítico é um trabalho de perda, de perda de gozo.
} 
sua obra, porém sempre pontuada, mesmo que de forma ligeira, pelas implicações da educação e da linguagem no movimento da cultura. Nesses textos, fica patente a incidência da psicanálise no mundo. Porém não é ao fenômeno que se fiará a leitura da psicanálise, mas sim à palavra, à cadeia significante, ao discurso. A psicanálise, na sua visitação à cultura, na interlocução com outros campos de saber, recolhe dela aquilo que lhe possibilita um avanço, além de permitir que lhe seja extraído aquilo que possa também fazer o outro campo avançar.

As questões que começam a surgir me direcionam a pensar essa aproximação entre psicanálise e educação como possível. Questões quanto ao ato de educar, quanto ao embaraço que se mascara no sintoma que aparece como queixa na clínica. Por que a escola, seguindo esse modelo do paradigma da modernidade, disciplinador e normatizador, encaminha a "criança problema" para "tratamento" quando se vê diante de um "não saber o que fazer"? Por que pais, ao chegarem com o filho para "tratamento", demandam que se dê "um jeito nesse menino", ou que se faça que "ele não aja mais assim"?

Frente ao não saber, é preciso buscar um outro que saiba, que tenha a resposta. Mas nesse intervalo entra a psicanálise que, diferente da psicologia, "não é, em sua estrutura mesma, uma ciência da observação” (Kupfer, 2007, p. 27). A psicanálise, por trazer no seu cerne a linguagem, dada a mal-entendidos, a tropeços e equívocos, trabalha com a interpretação, com a construção própria de cada sujeito, com um saber que é efeito dessa construção e não é dado a priori.

À medida em que pude avançar na leitura do texto freudiano e nos autores contemporâneos que versam sobre essa interface, essas primeiras questões que me inquietavam foram dando lugar a outras, menos abrangentes, mais específicas e menos direcionadas à prática clínica com as crianças que, juntamente com seus pais, batiam à porta do meu consultório em busca de respostas.

Tais questões passaram a ser dirigidas ao tema da transmissão da psicanálise, pois estando às voltas com a formação do psicanalista e a incidência deste campo na cultura, fui tomada pela inquietação sobre o que pode um analista na extensão. Não só na psicanálise em extensão, na transmissão da psicanálise aos analistas, mas também quanto ao que pode ser transmitido da psicanálise em outros espaços de formação, articulado a outros campos 
do saber, por exemplo, em um curso de formação de professores. Na sua visitação à cultura, o que a psicanálise traria, em seu discurso, que poderia servir à educação?

Voltolini (2002) já nos coloca uma questão muito próxima quanto ao "que é e para que transmitir psicanálise a educadores, ou seja, a alguém que não pretende ser analista?” Mas como saber a priori se há desejo de ser analista? O desejo do analista deve ser escutado na análise, como uma questão a ser trabalhada e servir de causa ao se tornar analista. É isso que Voltolini aponta ao colocar a questão da transmissão da psicanálise ao educador articulada ao que ela implica na sua prática e não ao que a psicanálise pode explicar quanto às queixas e aos problemas levantados pelo processo de ensinoaprendizagem. Ou seja, transmitir a psicanálise a educadores não necessariamente implica, que ao final, esse educador seja formado em psicanálise. Não é disso que se trata. Mas, certamente, ao final, esse educador não será um leigo em psicanálise. A transmissão da psicanálise a educadores implica sim nesse atravessamento, pelo discurso, pelo texto, pelos significantes da psicanálise, que possam trazer uma novidade, uma questão, ou mesmo possibilitar uma torção na posição do educador quanto a sua prática. A transmissão de um saber sobre e a partir da psicanálise não forma analistas. É preciso, como nos ensina Freud, a experiência na carne, a travessia analítica, a passagem pelo divã, o questionamento do sintoma, reconhecer o desejo, para "tornar-se psicanalista da sua própria experiência" (LACAN, 1967, p. 29). Porém, também não basta a experiência na carne, ou seja, a experiência do divã, a análise em intensão. A formação do analista está ancorada no tripé da análise pessoal, supervisão e ensino teórico. A experiência clínica se faz na dobradiça entre análise pessoal e direção de cura na escuta de pacientes. E, de forma alguma, esta é a finalidade de uma possível transmissão da psicanálise a educadores.

Freud nos alerta sobre o lugar da psicanálise - a cultura - e o lugar da sua transmissão - o divã. No artigo escrito em 1919, que traz como título a pergunta: "Deve a psicanálise ser ensinada na universidade?", Freud nos convida a pensar o que é da ordem do ensino e o que se trata de transmissão. Neste artigo, ele discorre sobre a formação do analista, apontando que este pode prescindir da universidade não sendo esta o lugar para sua formação. Reafirma que a formação do psicanalista se dá pela experiência, pela travessia analítica, pela convicção do inconsciente. Mesmo desejando inscrever a psicanálise no rol das ciências, descrevendo e comprovando seu método de investigação, 
Freud se vê impelido, pelos fundamentos e pelo rigor da sua prática, a não manter a psicanálise "dentro do discurso acadêmico", mas sim "torná-la patrimônio da cultura" (KUPFER, 2007, p. 26).

Alguns anos depois da escrita deste texto o qual situa a psicanálise como patrimônio da cultura e o divã como o lugar por excelência de sua transmissão, Freud (1926) se debruça sobre a defesa da análise leiga, não restringindo sua prática aos médicos, como foi a tentativa feita para enquadrá-la "como um anexo da psiquiatria” (SAFOUAN, 1989, p.).

Assim, Freud diz numa "rara entrevista":

Estou escrevendo uma defesa da análise leiga, da psicanálise praticada por leigos. Os doutores querem tornar a análise ilegal para os não-médicos. A História, essa velha plagiadora, repete-se após cada descoberta. Os doutores combatem cada nova verdade no começo, depois procuram monopolizá-la." (FREUD, 1926, s/p)

A partir da sua incidência na cultura, a psicanálise passou a ser alvo de interesses, assim como de críticas. O novo discurso que ela inaugura não é sem consequências e sem efeitos para a cultura. A psicanálise, inicialmente alvo de críticas e descrença, passou a ganhar espaço, prestígio e adeptos, inscrevendo-se na cultura como uma nova terapêutica, capaz de tratar as afecções nervosas. Porém, a psicanálise mostrou-se mais que uma simples terapêutica. Apresenta-se como um novo discurso na cultura, a partir da invenção do conceito de inconsciente e de um novo lugar dado ao sujeito, subvertendo a ética e trazendo o desejo como motor do funcionamento psíquico.

Assim, seguindo o discurso capitalista vigente e a mercantilização e monopólio do serviço médico, além da tentativa de garantir a formação do psicanalista pelo viés da medicina, surge a tentativa, rechaçada por Freud, de restringir a prática clínica da psicanálise aos médicos.

É desta forma, antecipando a questão da análise leiga, que Freud escreve, em 1925, o "Prefácio à Juventude Abandonada", livro de August Aichhorn, um dos poucos trabalhos de sua obra que traz uma contribuição clara e sua posição quanto ao campo da educação. Aponta a importância da psicanálise "não para a teoria da educação, mas para a condição daqueles que estão empenhados na educação" (1925, p. 308). E completa, escrevendo:

"Quando o educador apreendeu a análise através da experiência na sua própria pessoa, podendo estar em condições de utilizá-la como apoio de 
seu trabalho em casos limites ou mistos, deve-se, então, permitir-lhe manifestamente o exercício da análise e não é lícito querer impedi-lo por motivos mesquinhos". (1925, p. 5)

A leitura atenta do artigo sobre a análise leiga, no qual Freud debate com um interlocutor imaginário sobre os caminhos, desvios e avanços da psicanálise, coloca-nos de cara com o que posteriormente Lacan vai dar o nome de desejo do analista. Lacan, no seu retorno a Freud, ao texto freudiano e aos fundamentos dos conceitos psicanalíticos, recoloca a psicanálise nos trilhos e denuncia o caminho desviante que esta seguiu com os pós-freudianos. Neste retorno, Lacan dá um passo a mais, vai com Freud além de Freud, colocando a questão da formação do analista na ordem do dia.

A análise é leiga. Porém, não basta um simples querer ser analista. O desejo não é da ordem da vontade. Tomando o dito popular de que a vontade dá e passa, que tem sua verdade, podemos dizer que o desejo é de outra ordem, já que ele insiste em ser escutado.

Devemos estar atentos à leitura deste texto para não cairmos no engano e na utopia de que o educador deve ser analisado e de confundir os campos da educação e psicanálise. Não se trata de uma exigência de análise para que se possa ser educador, assim como não basta a análise para um educador tornar-se analista. Se assim fosse, estaríamos caindo num desvio e idealizando um novo método ou técnica psicanaliticamente orientada que pudesse dar conta de responder às questões quanto ao ato de educar.

Essas questões foram trabalhadas de forma detalhada e precisa por Catherine Millot em seu livro "Freud Antipedagogo". Millot retoma a posição de Freud quanto à educação e também ali denuncia os desvios do uso equivocado da psicanálise pelo campo psicopedagógico. Ela é taxativa em ratificar a posição freudiana de que psicanálise, enquanto prática terapêutica, e educação são campos distintos, que não podem ser substituídos um pelo outro e muito menos tomar a psicanálise como uma nova possibilidade de método, de orientação ou técnica de ensino.

\footnotetext{
“(...) há uma disjunção, regra geral, entre a tarefa pedagógica e a relação terapêutica. A psicoterapia é realizada por um analista que não desempenha função educacional. Relação educativa e relação analítica estão separadas." (MILLOT, 2001, p. 145)
}

$\mathrm{O}$ ato educativo se opõe ao ato analítico. A função do analista, na direção da cura, não é educar o analisante, mas trabalhar na escuta dos significantes, da estrutura, permitindo uma perda de gozo, o reconhecimento do desejo e a mudança subjetiva que, 
como nos ensina Freud, permita ao sujeito estar mais liberado para o amor e o trabalho, deslocando-se do sofrimento neurótico e vivendo a infelicidade comum. Na direção da cura, é preciso que o analista ocupe o lugar de morto, como diz Lacan. O analista paga com o seu ser, com a moeda da neutralidade. O único sujeito que fala numa análise é o sujeito do inconsciente do analisante. Millot nos coloca que "o educador, pai ou pedagogo, não pode pretender a mesma neutralidade" (2001, p. 152). No ato educativo, o educador está como sujeito, emaranhado em suas questões, submetido aos seus significantes, sintomas e desejos, operando a partir deles. O único desejo presente no ato analítico é o desejo do analista, servindo de causa ao desejo do analisante.

O educador (pai, mãe, ou mesmo professor), ou seja, aquele que está empenhado no ato de educar, tem uma função fundamental na constituição do sujeito infantil, na estruturação desse sujeito e na inscrição do desejo. Como já pontuei anteriormente, o sujeito se constitui no campo do Outro e esse Outro, esse tesouro do significante, é quem pode transmitir ao sujeito infantil a chave para seu desejo. Sendo assim, o que o educador pode fazer para ser entrecortado pela psicanálise?

Freud sustenta, até o final de sua obra, a importância da experiência analítica para a convicção do inconsciente. Ponto este retomado e ratificado por Lacan. É inegável que o submetimento a uma análise traz uma mudança subjetiva. O ensino teórico de seus conceitos é possível a partir da construção de um saber sobre e a partir da psicanálise, mas não traz nenhuma convicção. Porém, o atravessamento pelo texto, ser entrecortado pelos significantes freudianos, pelos significantes da psicanálise, têm também uma importância fundamental para aquele que está na função de educador. Freud, ainda neste "Prefácio...", nos alerta quanto ao lugar desses dois campos, que embora possam conversar e estarem implicados, não podem ser confundidos nem substituídos um pelo outro.

\footnotetext{
"A psicanálise da criança pode ser utilizada pela educação como um meio auxiliar, mas não é apropriada para tomar seu lugar. Não somente fundamentos práticos o proíbem como também considerações teóricas o desaconselham. A relação entre educação e tratamento analítico será provavelmente, em um tempo não remoto, submetida a um profundo exame."(Freud, 1925, p. 5)
}

Na citação acima, Freud aborda a relação entre educação e tratamento analítico, apontando a distinção de cada uma dessas práticas. É a essa relação na qual se pautou Catherine Millot, concluindo a impossibilidade e a impotência de uma pedagogia 
psicanaliticamente orientada.

Todavia, é também a partir desse ponto que Maria Cristina Kupfer (2007) dá um passo nesta relação entre psicanálise e educação, apontando a possibilidade de um rico diálogo, de uma troca, a partir do atravessamento do discurso psicanalítico e daquilo que os campos da psicanálise e da educação têm em comum, ou seja, a linguagem como seu instrumento de trabalho. O passo dado por Maria Cristina Kupfer nessa interlocução situa cada um desses campos em seu lugar, seguindo com rigor a indicação de Freud, contudo deflagra uma nova possibilidade de leitura, da educação como um discurso com o qual a psicanálise faz laço social.

Freud, neste mesmo "Prefácio", de 1925, inclui a psicanálise, esse novo discurso inaugurado por ele, na série das profissões "impossíveis" enunciadas por Kant, a saber, educar e governar. Tais práticas, por terem a linguagem, a palavra, como instrumento, estão sujeitas a mal-entendidos e nunca alcançam resultados plenos e completamente satisfatórios. Posteriormente, em 1937, ao escrever "Análise terminável e interminável", Freud novamente faz referência à psicanálise como uma das profissões impossíveis, ao tratar, no ponto VII, da formação do analista e da exigência ética, necessária, mas não suficiente, de uma firme convicção da existência do inconsciente para se exercer a psicanálise.

Lacan retoma as três posições impossíveis colocadas por Freud tratando-as como discursos, que são quatro: o Discurso do Analista, que faz referência à impossibilidade de psicanalisar; o Discurso do Mestre, fazendo referência à impossibilidade de governar; o Discurso da Universidade, referindo-se à impossibilidade de educar; e acrescenta ainda um quarto discurso, o Discurso da Histérica, fazendo referência à impossibilidade de se histericizar, de fazer desejar. Designa tais profissões como posições insustentáveis, “justamente por ser aquilo em direção à qual todo mundo se lança” (2005, p. 57). Salienta que, na educação, a posição daquele que se lança a educar é considerada vantajosa. Não faltam candidatos e muitos ainda recebem a autorização para tal, mesmo sem perceber muito bem o que pretendem quando educam e mesmo tentando ter uma idéia, raramente refletindo sobre ela. Mas de tempos em tempos são tomados pela angústia, ao pensarem no que consiste educar: tarefa árdua, que muitas vezes desaloja o sujeito/educador de sua 
posição.

Se o objetivo desta interlocução não está em propor um novo método ou técnica com base psicanalítica para dar conta das questões da prática educativa, então, o que nos interessa? É justamente o que Freud nos aponta na citação acima, ou seja, que essa relação entre psicanálise e educação seja submetida a um exame profundo e que possamos tirar dela seus efeitos.

Em 1913, Freud trabalha sobre o "Múltiplo interesse da psicanálise", trazendo para a ordem do dia suas possíveis contribuições a diversos campos, possibilitando a leitura deles à luz de seu discurso. Este é um dos poucos artigos na obra freudiana que versam sobre o interesse educacional da psicanálise. A Psicanálise se apresenta, nesta interface com outros campos, como um novo instrumento de trabalho, possibilitando uma nova leitura.

\footnotetext{
"A psicanálise é um processo médico que aspira curar certas formas de nervosidade (neurose) (...) Esta importância médica da psicanálise não justificaria a tentativa de apresentá-la num círculo de homens de estudo, interessados pela síntese das ciências, e muito menos agora quando tal empresa parece prematura, pois uma grande maioria dos psiquiatras e neurologistas continua mostrando-se contrária ao novo método terapêutico e repele não só suas hipóteses como seus resultados. Se, apesar de tudo, considero legítima esta tentativa, é porque a psicanálise aspira interessar os homens de ciência fora dos círculos psiquiátricos, pois se estende a outros setores científicos diferentes e estabelece entre eles e a patologia da vida psíquica relações até então desconhecidas."(Freud, 1958 [1913], p. 196)
}

Freud, em um de seus textos no qual versa sobre o tema da educação, lamenta-se por ter sido modesta sua contribuiç̧ão a esse campo, mas ressalta que este tema e o emprego da psicanálise na teoria e prática da educação despertaram grande interesse e atraíram muitos colaboradores. Ao dizer que esta contribuição tem "um grande valor social", podemos ratificar a importância da implicação desses dois campos para a cultura e para um avanço na civilização.

Para Freud, sua contribuição pode ter sido modesta, mas pra nós ela é riquíssima. Embora tenha escrito poucos artigos nos quais expõe claramente seu pensamento quanto ao campo da educação, este tema perpassa toda sua obra e está articulado, dando suporte, a conceitos fundamentais da teoria psicanalítica, tais como o recalque, a pulsão, o ideal, a transferência, a sexualidade. Se a educação é instaurada no mesmo golpe que também 
instaura a cultura, e se o homem, o sujeito do inconsciente, constitui-se no campo do Outro, não é sem a educação.

Durante todo o percurso desta dissertação, estaremos lendo e trabalhando a educação por esse viés simbólico. Ou seja, trabalharemos a educação da sua relação com a cultura, com o avanço da civilização. Essa educação que está articulada ao simbólico, à transmissão de um legado, à tradição e à história de vida de cada sujeito, educador e aprendiz. Não há como ignorar a educação formal, institucionalizada. Nem é esta a proposta desse trabalho, haja vista seu endereçamento à formação de educadores. Porém, a educação formal pauta-se no viés imaginário, idealizante, da completude e da satisfação plena, ponto onde tantas teorias e métodos se fixam, na tentativa e na busca de uma educação plena de sucesso.

Pensar a educação atravessada pela psicanálise é promover o nó entre simbólico (educação como prática cultural), imaginário (educação formal, as técnicas e métodos de ensino-aprendizagem) e real (educação marcada pela falta, pelo impossível, pelo ineducável). A psicanálise, o discurso psicanalítico, torna-se o operador desse enlace, fazendo a amarração borromeana necessária, apontando o impossível da educação plena e a não primazia do imaginário, pois para além dele está o simbólico, marcado pelo desejo.

Serão raros os momentos em que estaremos abordando a educação formal, institucionalizada, pelo olhar da escola. É também inevitável passar por esse aspecto da educação, haja vista que todo nosso sistema de ensino está organizado desta maneira, seguindo este paradigma da contemporaneidade. Paradigma que estabelece o acúmulo e o ter como fundamentais, que apaga o sujeito na sua singularidade, exigindo deste a adaptação, o enquadramento, a repetição. Paradigma que abole as diferenças, o estilo próprio, e valoriza o igual, o mesmo, o adequado. Porém, o convite que está sendo feito neste texto, é para uma leitura mais limpa, menos contaminada pelos conhecimentos prédeterminados sobre a educação. A aposta que está sendo feita aqui é de trazer para a educação um frescor, uma brisa do ineditismo da descoberta, da surpresa. Mia Couto, no prefácio de seu livro "O gato e o escuro", diz de maneira singela que o que o "encanta no acto da escrita é surpreender tanto a escrita como a língua em estado de infância. E lidar com o idioma como se ele estivesse ainda em fase de construção, do mesmo modo que uma 
criança converte o mundo inteiro num brinquedo" (2008, p. 5).

É preciso surpreender-se em estado de infância, tanto para que possa ser atravessado por essa leitura, por esse texto, quanto para que possa se colocar na função de educador. É preciso surpreender-se em estado de infância para que um saber possa ser construído, para que mesmo aquilo sobre o qual já temos um conhecimento teórico possa ter um novo frescor na prática.

Ao abordar o interesse educacional da psicanálise, Freud (1996[1913]) nos ensina sobre a importância do lugar e da posição do educador.

\footnotetext{
"Somente alguém que possa sondar as mentes das crianças será capaz de educá-las e nós, pessoas adultas, não podemos entender as crianças porque não mais entendemos a nossa própria infância. Nossa amnésia infantil prova que nos tornamos estranhos à nossa própria infância" (Freud, 1996[1913], p. 190).
}

Submetidos à barra do recalque, estamos sujeitos à amnésia infantil. Não recordamos as marcas deixadas pela infância, não recordamos esse momento constitucional de forma consciente. As recordações são fragmentárias, entrecortadas pelas fantasias, as quais Freud nomeia como recordações encobridoras. Desse momento tão significativo restam apenas representações disjuntas do afeto; representações que são submetidas ao mecanismo do recalque e que só podem vir à tona para serem elaboradas a partir da suspensão deste.

Sendo assim, não se trata aqui de compreender a própria infância, no sentido do conhecimento, de uma racionalidade consciente, de um saber a priori, mas sim da possibilidade de aceder ao enigma infantil, de se tornar menos estranho à própria infância. É preciso que a dimensão do enigma esteja em causa, é preciso surpreender-se em estado de infância para exercer a função de educador.

Esta fala de Freud faz eco na fala de Couto, trazendo a dimensão da surpresa, do inédito, do enigma. Sem a possibilidade de aceder ao enigma da criança, de se surpreender neste estado infantil, de se deliciar com o entusiasmo da descoberta, estaremos presos a uma leitura da educação única e exclusivamente pelo viés do engodo da pedagogia, ou seja, da ciência da educação. Educação e Pedagogia não são uma única e mesma coisa, como nos mostrou Kupfer ratificando o pensamento de Millot. A educação está para além da ciência pedagógica, sustentando-se numa prática que não tem como base fundamental e única 
direção o ensinar, instruir, referindo-se a um saber teórico, baseado no acúmulo e no conhecimento acumulado. Sendo uma prática, a educação está sustentada em um saber.

E que saber nos interessa? Tendo o discurso psicanalítico como esteio desse trabalho, o que está em causa aqui é o saber inconsciente e não o conhecimento intelectual. "Para a psicanálise, o saber é um enigma - e esse enigma nos é presentificado pelo inconsciente tal como se revela no discurso analítico" (Barros, 1999, p. 262).

Ao trabalhar a hiância e as articulações entre saber e conhecimento, Iara Barros nos coloca uma questão: "Seria o saber como enigma, como não-saber, a mola que move o conhecimento?" (1999, p. 263).

Está em Freud a afirmação de que o conhecimento teórico não traz nenhuma mudança subjetiva, nem a convicção do inconsciente. O conhecimento teórico, intelectual, sistematizado, conteudista, não produz saber inconsciente. Como nos aponta Lacan, o saber adquirido dessa forma explicativa, associado à aprendizagem, é uma invenção dos pedagogos. "Saber algo não é sempre algo que se produz como um clarão?" (LACAN, 2008, p. 196). A ilusão da pedagogia, assim como do campo filosófico, é acreditar alcançar um saber pleno, absoluto, total. Mas o saber não é cumulativo, é furado e se produz como um clarão. O saber só se produz a partir de uma construção, de uma experiência que se faz pagando com a perda de gozo. Para que haja uma construção da experiência de saber, é preciso deixar cair a ilusão da aquisição do conhecimento, da busca por respostas, e sustentar a dimensão do enigma, mantendo acessa a chama da pergunta, não buscando incessantemente a reparação da falta e sim sustentando-a.

\footnotetext{
"Talvez possamos dizer que o sintoma da Pedagogia seja a construção dessa ilusão, a incessante busca de reparação de faltas; talvez não tenham sido gastas tantas e tantas páginas, em tempos e histórias diferentes, para dizer o que deveria ser, mas para tamponar o impossível de ser feito"(LOPES, 2001, p. 55).
}

Mas será que a porta aberta pela ascensão ao saber inconsciente não nos possibilitaria também a aquisição de conhecimentos? Trabalharemos no quarto ensaio dessa dissertação, "Educação: Ensino e/ou Transmissão? Os giros discursivos e a formação", sobre esta articulação e disjunção, tomando como fio condutor a inversão dessa lógica pedagógica da aquisição de conhecimentos, do ensino-aprendizagem, para uma possível construção do saber, para um apreender, a partir da sustentação da dimensão do enigma. 
Daí surge o título dessa dissertação, na aposta nessa torção a partir do discurso psicanalítico atravessando a posição do educador.

Assim retorno à questão motriz desse trabalho, colocada anteriormente. O que a psicanálise, ou o discurso psicanalítico, traz de implicações ao campo educacional, mais precisamente à formação e à posição do educador?

A articulação que se faz aqui se refere à extensão da psicanálise, à sua visitação à cultura e não à clínica psicanalítica. Com relação ao trabalho analítico, os efeitos são elaborados por cada um que se submete a essa experiência de saber.

Como, então, encaminhar tal questão? Unicamente a partir do atravessamento do discurso psicanalítico na posição do educador, na torção que esse discurso implica na posição daqueles que são atravessados por ele. É ao educador que se dirige esse texto, ao educador atento à sua prática, à sua experiência, que se coloca uma questão quanto ao seu ato; ao educador, alvo de identificações, de transferências, de afetos tão ambivalentes.

No texto "Algumas considerações sobre a psicologia do escolar" (1914), escrito em comemoração aos 50 anos do colégio onde estudou, e outro dos poucos textos nos quais versa claramente sobre o tema da educação, Freud faz uma homenagem ao professor/educador. Ele acende a luz da importância da figura deste na constituição e nas escolhas do sujeito a partir das marcas deixadas tão profundamente cravadas na vida daqueles que os tiveram como modelo. Freud aponta a importância daqueles anos escolares na sua forma de conceber a civilização e a cultura, na sua escolha profissional, nos interesses que lhe foram despertados, enfim, na importância desses anos naquilo que ele se tornou.

Assim escreve sobre o lugar ocupado pelo professor/educador na economia psíquica do sujeito:

"É difícil dizer se o que exerceu mais influência sobre nós e teve importância maior foi a nossa preocupação pelas ciências que nos eram ensinadas, ou pela personalidade de nossos mestres. É verdade, no mínimo, que esta segunda preocupação constituía uma corrente oculta e constante em todos nós e, para muitos, os caminhos das ciências passavam através de nossos professores" (FREUD, 1996[1914], p. 248).

Freud traz neste texto indicações importantíssimas quanto à transferência, mecanismo que está em jogo amarrando a relação entre educador e aprendiz. A 
transferência não é um privilégio da psicanálise, mas sim um produto da neurose, que permeia os laços sociais, as relações do sujeito com o outro. O educador é alvo de amor e ódio, de admiração e rechaço, ambivalência constitucional das afeições do sujeito. Amor e ódio são faces da mesma moeda, assim como transferência e resistência. Esse amor provocado pela transferência, amor pelo saber suposto ao Outro, dirigido ao educador, pode tanto possibilitar a transmissão quanto ser um grande obstáculo a ela.

Estar atento a esse funcionamento psíquico, ao fenômeno da transferência, estar atento de que muitas vezes aquela atitude que nos desagrada, atitude hostil, ou mesmo aquele amor desmesurado de que somos alvo, não está dirigido à pessoa do educador, mas sim àquilo que ele representa, ou seja, estar atento a isso é de fundamental importância na prática educativa.

Teremos oportunidade de trabalhar e discorrer mais sobre esse conceito no próximo ensaio, que tem como título "A Psicanálise na escuta da Educação: um lugar para a transferência" e nos determos mais sobre a importância do educador estar avisado do lugar que ocupa na economia psíquica e na constituição do sujeito.

Gostaria ainda de salientar o que Freud nos traz no texto "Por que a guerra?" (1933), uma resposta a Albert Einstein quanto ao questionamento sobre sua posição e a posição da psicanálise diante da força exercida pelo homem em busca do poder e da capacidade deste de tantas atrocidades, pela força. Freud aponta o caráter estrutural, constitucional, dessas pulsões de dominação e de destruição, que precisam de uma barra, um dique, posto pela educação. Sendo assim, insiste na importância, não de se domar essa pulsão, mas de uma renúncia pulsional necessária para que haja um avanço na civilização. Porém, não há como eliminar as tendências agressivas do ser humano. Há um indomável, uma quota ineducável da pulsão. É nesse sentido que Freud aponta a importância de se atentar para a educação dos líderes, para que esses possam se colocar de forma menos “dominadora" frente ao poder.

"Um exemplo de desigualdade inata e irremovível dos homens é sua tendência a se classificarem em dois tipos, o dos líderes e o dos seguidores. Esses últimos constituem a vasta maioria; têm necessidade de uma autoridade que tome decisões por eles e à qual, na sua maioria devotam uma submissão ilimitada. Isto sugere que se deva dar mais atenção, do que até hoje se tem dado, à educação da camada superior dos homens dotados de mentalidade independente, não passível de intimidação e desejosa de manter-se fiel à verdade, cuja preocupação seja a de dirigir as massas dependentes" (FREUD, 1996 [1933], p. 205). 
Pode nos parecer, numa leitura apressada, fora do contexto trabalhado no texto "Por que a guerra?", uma colocação um tanto preconceituosa. Porém, trazendo essa colocação para o campo que nos interessa, da educação, da formação do educador e da ética, ela se faz pertinente. É a esses, educadores, alvos de identificações, que se deve dirigir uma atenção mais incisiva, para que tenham recursos para lidar com a transferência e a demanda dirigidas a eles, para que possam sustentar o seu lugar de "suposto saber" da verdade, sem, no entanto, encarnar esse saber. Ou seja, sem tomar para si tal saber, não sendo o dono da verdade, mas sim aquele que possa, a partir do seu lugar, causar o desejo de saber no aluno permitindo que este possa tomar posse de seu saber e não fechando qualquer possibilidade de construção.

Ainda nos resta abordar neste primeiro tempo o percurso desse trabalho de pesquisa e os referenciais aos quais recorrerei para avançar na questão que me impele a esse labor. A pesquisa que se pretende com esse projeto é teórica, mas não no sentido da teoria pura, referencial, mas sim naquilo que ela possa se articular à prática, ou seja, nos efeitos que o saber teórico possa trazer para o saber textual, o saber que se articula à própria experiência.

O texto que será produzido como efeito desse trabalho de pesquisa não se pretende completo, pronto, acabado. Certamente ele será entrecortado por lacunas, hiatos, que permitirão ao leitor, a partir do seu próprio texto, lançar sua luz, colocando algo de seu e podendo assim extrair para si os efeitos de ter sido afetado por essa leitura.

O referencial teórico do qual lanço mão para percorrer esse caminho sustenta-se na psicanálise, no discurso inaugurado por Freud e na prática clínica retomada por Lacan. É seguindo o estilo legado por esses autores, principalmente no que se refere à sustentação do desejo do analista e da causa psicanalítica, que me endereço a esse trabalho.

A aproximação entre psicanálise e educação não é inédita e muito já vem sendo produzido sobre essa interface. Porém, tais produções estão sempre articuladas a um tema específico, como a questão da violência, do fracasso escolar, da inclusão social, da saúde mental. Muitos autores contemporâneos, em geral psicanalistas, debruçam-se sobre esse tema, inclusive articulando-o à prática clínica. Contudo, pouco foi encontrado na revisão de literatura, das produções mais recentes, sobre a possível transmissão da psicanálise aos educadores, ou seja, da implicação do discurso analítico na formação do educador. Ao 
longo do quarto ensaio, "Educação: Ensino e/ou Transmissão? Os giros discursivos e a formação", será trabalhado o possível ensino e transmissão da psicanálise a educadores. Ensino e transmissão que não se pretendem como aquele da formação do analista, porém que traz em seu cerne a subversão dessa formação, fazendo uma disjunção entre ensino e transmissão e possibilitando um passo naquilo que se refere à formação do educador.

Em seu livro "O avesso do modelo - Bons professores e a psicanálise”, Marcelo Ricardo Pereira traz essa discussão, porém como referencial teórico-metodológico utiliza a análise de discurso.

O eixo central de discussão neste trabalho se aproxima do abordado por Marcelo Ricardo Pereira, todavia seguirá um percurso bastante distinto, pois se sustentará no rigor do texto e dos conceitos psicanalíticos, na apuração de um estilo próprio a partir da transmissão e do que há do estilo de Freud e Lacan.

Este minucioso trabalho de pesquisa que tem o escrito como efeito, não irá a campo, nem lançará mão de observações, entrevistas, questionários ou grupos focais, mas perseguirá os significantes, colherá o que se pode escutar da estrutura e do gozo, e será pontuada por fragmentos, por vestígios do dizer cotidiano sobre o ato de educar.

Ao longo dos demais ensaios serão trabalhados conceitos psicanalíticos que podem se estender ao campo da educação, ou mesmo que já foram absorvidos por ele, tais como: sujeito, transferência, saber, inconsciente, discurso, ensino, transmissão, complexo de Édipo, sexualidade infantil.

Para finalizar, lanço mão de uma citação de Freud (1996[1905]) em seu texto "Sobre a psicoterapia", no qual faz uma aproximação da psicanálise com as artes, nas fórmulas per via di porre e per via di levare, de Leonardo da Vinci. Ouso estender tal aproximação ao campo da educação.

\footnotetext{
"A pintura trabalha per via di porre, deposita sobre a tela incolor partículas coloridas que antes não estavam ali, já a escultura, ao contrário, funciona per via di levare, pois retira da pedra tudo o que encobre a superfície da estátua nela contida" (FREUD, 1996[1905], p. 247).
}

Enfim, o convite aberto à interlocução da psicanálise com a educação é um convite na aposta de se fazer uma passagem do ideal, da ilusão, ao estilo. É poder sair desse ideal que aprisiona, inatingível, que cega e não permite um avanço. Ideal que apenas fascina e recobre o real, instaurando a impotência. Fazer essa passagem implica apropriar-se do 
estilo, próprio de cada um, marcado pelo embaraço, pela incompletude, pela impossibilidade de satisfação plena, mas que aponta um caminho, uma posição singular diante da tarefa de educar.

Isso se sustenta no fato de que não há uma educação plena de satisfação. Há sempre um ponto impossível de educar, uma quota ineducável da pulsão. A expectativa de uma educação plena é uma ilusão que esbarra na fantasia sustentada pela dimensão idealizante, pela insistência do mecanismo do desmentido estrutural.

A vertente idealizante, a ilusão de uma totalidade, não permite a escuta da diferença, do particular, colocando o professor no lugar de mestre que tem as respostas à demanda de saber. Esse ideal de completude, de igualdade, de enquadramento, apaga a diferença, privilegia a resposta e impede que seja sustentada uma pergunta.

O ideal aponta para a busca de uma normalidade; é o privilégio da igualdade, do enquadramento e da classificação. Aquilo que está fora da regra, do esperado, do já sabido, não tem lugar, é visto como "errado". O ideal aponta para uma exigência superegóica e privilegia a ética do bem, ou seja, afasta-se da ética da psicanálise, na qual o julgamento e o moralismo passam ao largo e o que está em questão é o desejo.

O que a psicanálise pode oferecer à educação é sua escuta, seu discurso e sua ética. Ética que privilegia o desejo, o dizer, o enigma, a diferença. Ética que privilegia o saber inconsciente, a construção do sujeito ao se desvencilhar do ideal e apropriar-se do seu estilo.

A ética da psicanálise, ancorada no desejo, faz cair esse ideal totalizante e permite ao sujeito ser agente e autor da sua própria história. O psicanalista, na escuta da educação, através do que dizem os educadores, pela sua posição frente ao ato de educar, deve seguir a mesma lógica de sua prática, e sua intervenção na educação, na cultura, dá-se a partir da ética e do desejo do analista. Sendo assim, o que o educador pode aprender sobre e a partir da psicanálise, como nos aponta Millot (2001), "é saber pôr limites à sua ação - um saber que não corresponde a nenhuma ciência, e sim à arte". (p. 154) E se o educador pode dar esse passo, do ideal ao estilo, reinventando a sua arte de educar, ele pode também se atentar para um outro ponto de fundamental importância no ato de seu ensino, a saber, a transferência. 
A Psicanálise na escuta da Educação: um lugar para a transferência 
Uma pergunta se instaura de imediato ao ler o título desse capítulo: a psicanálise escuta a educação? Ou, melhor dizendo, o lugar da psicanálise, na interlocução com outros campos de saber, na interlocução com a educação, campo que nos interessa, é um lugar de escuta? A psicanálise deve se colocar a escutar a educação? Como?

Fiquemos neste primeiro momento com a pergunta para tentarmos avançar no ponto sobre o que pode um psicanalista na psicanálise em extensão, principalmente na interlocução com esse campo tão vasto e profícuo da educação.

Primeiramente, cabe-nos apurar o significante interlocução. Do que se trata?

Interlocução, no dicionário, apresenta-se como "conversação entre duas ou mais pessoas". E interlocutor é "aquele que fala com outro, ou em nome de outro." No caso em que tratamos aqui, a interlocução vai além de uma simples conversação entre duas pessoas ou dois campos de saber. A interlocução implica também a escuta, a experiência e o que de um campo está implicado no outro. São campos distintos que podem estar atravessados por questões comuns no laço social. E o que esses dois campos tão distintos poderiam ter em comum? Para limitarmos ao que nos interessa, podemos apontar como principal ponto de articulação a relação desses dois campos com o saber.

Quando falamos de escuta estamos introduzindo aqui o instrumento com o qual o psicanalista trabalha na direção da cura. É com sua escuta flutuante dos significantes que escapam, na fala do sujeito, significantes da transferência, que o analista se oferece no trabalho analítico ao sujeito, e este, ao assumir o compromisso com a regra fundamental de associar livremente, vai tomando o fio de sua trama significante.

Se o que a psicanálise poderia oferecer à educação é sua escuta e sua ética, conforme finalizamos o capítulo introdutório desse ensaio, essa escuta é entrecortada e sustentada pela transferência. A transferência propicia trabalho. Não há escuta, no sentido que a psicanálise toma esse instrumento, sem transferência. Sendo assim, para que a psicanálise possa se colocar a escutar a educação, é preciso que a transferência esteja em campo. $\mathrm{Na}$ análise, a transferência propicia o trabalho analítico. Nesse trabalho, a transferência comum, que permeia as relações sociais, torna-se um instrumento de grande valor. O analista faz uso dessa transferência e a partir da posição de "encarar as coisas de um ponto de vista diferente" permite uma torção nesse amor, propiciando assim a 
instauração da neurose de transferência. É o que Freud aponta no caso clínico do "Pequeno Hans", ao dizer que sua neurose ganhou força e seus sintomas se acirraram a partir da instauração da neurose de transferência, de sua transferência dirigida ao professor, que sabe sobre sua "bobagem".

A incidência da psicanálise na cultura, assim como sua contribuição, aplicação ou sua articulação com outros campos de saber, sempre esteve presente na obra freudiana. Freud, ao discorrer sobre o múltiplo interesse da psicanálise, ressalta-o como um ponto de preocupação principalmente quanto aos rumos que esta poderia tomar, quanto à sua teoria e sua prática, assim como quanto ao uso feito (ou mau uso) de seus conceitos fundamentais. Ao percorrer a obra freudiana, é possível acompanhar os avanços de Freud quanto às suas expectativas frente à psicanálise e o corte que esse discurso faz na cultura. Embora sua posição tenha sido, desde o começo, sem ilusões ou grandes pretensões, Freud traz nos seus escritos de 1908/10, a crença e a aposta de que com uma educação menos repressora e livre dos tabus da sexualidade seria possível remediar a neurose. Essa premissa se balizava ainda nas suas primeiras descobertas dos "Estudos sobre a histeria" e da "Etiologia das neuroses". Ao prosseguir com suas investigações e sua prática clínica, Freud avança quanto à possível aplicação da psicanálise na pedagogia, sendo este o campo de estudo que abriga a educação formal. Porém ainda sustenta a aplicação da psicanálise na educação como profilaxia para as neuroses, apontando o caminho utópico de que todo educador fosse submetido a um tratamento analítico. É somente ao final de sua obra, após elaborar o conceito de castração e ao se deparar com seu rochedo intransponível, ao postular sobre aquilo que há de constitucional no sujeito, que Freud apontará a articulação, ou como viemos trabalhando neste ensaio, a interlocução, da psicanálise com a educação, a partir daquilo que esses dois campos têm em comum, ou seja, um impossível de saber, um ponto de falta, um resto inanalisável, ineducável; a educação, assim como a psicanálise, tomada como prática impossível. Porém apontar a prática educacional como impossível é a visada que a psicanálise faz desse campo. Para o campo educacional, esse impossível não está

\footnotetext{
${ }^{6}$ É assim, com esse significante, "bobagem", que Hans se refere ao seu sintoma, à sua fobia de cavalos. Freud não tratou Hans, mas orientava seu pai, que era seu aluno, para que este pudesse conduzir tal tratamento e possibilitar o desaparecimento dos sintomas fóbicos do menino. Hans esteve uma única vez com Freud, ao qual se referia como "Professor". E é a partir desse encontro que a "neurose de Hans ganha força, os sintomas se intensificam e ele passa a fazer referências constantes à Freud, como aquele que sabe e pode fazer desaparecer sua "bobagem".
} 
claro, causa embaraços e é denegado na tentativa constante de escamotear e tamponar aquilo que escapa. O fracasso, a aprendizagem insatisfatória, os problemas de aprendizagem, assim como todos os outros sintomas deflagrados na escola, são sempre trabalhados na tentativa de serem arrancados, eximidos, mas não escutados como algo que denuncia um funcionamento outro, que denuncia que algo ali não caminha bem. É essa denegação desse impossível, desse ponto de falta radical e estrutural que faz com que uma busca incessante por novos e bons métodos e técnicas suficientes de ensino-aprendizagem ocupe o dia a dia da prática e da pesquisa em educação. A psicanálise, a partir dessa leitura do campo educacional marcado pela falta, ancorado nesse impossível da totalidade e da completude, vem apontar nessa interlocução uma nova visada sobre a prática educacional. A psicanálise escuta a educação, a partir do fenômeno da transferência, a partir daqueles que estão na tarefa de educador, ou seja, os educadores. E a psicanálise também faz uma leitura da educação, a partir do seu discurso e daquilo que este pode ler do laço social.

Se nos cabe aqui pensar e apurar a interlocução entre a psicanálise e o campo da educação, é importante situar os vários momentos na obra freudiana onde essa contribuição, no sentido de uma aplicação, da psicanálise à pedagogia, é mencionada, como pudemos abordar na introdução desse ensaio. Freud afirma sempre que esta contribuição foi pequena ou quase nula, porém não nega que "era natural que os descobrimentos analíticos referentes à vida sexual e ao descobrimento anímico das crianças atraíssem a atenção dos pedagogos e lhes apresentassem seu trabalho educativo sob uma nova luz" (FREUD, 1925, p. 139). É sob essa nova luz que também algo novo, inédito, pode ser experimentado na prática, a partir do atravessamento do discurso psicanalítico.

A psicanálise, tornando-se um novo discurso na cultura, não se limita somente ao tratamento das afecções nervosas. Não se configura apenas como mais uma técnica ou método terapêutico. O discurso psicanalítico traz no seu cerne uma leitura do mal-estar da civilização. É esta a incidência que este discurso faz na cultura, ou seja, a possibilidade de, a partir dele, lê-se tal mal-estar. Não sendo mais uma técnica ou método terapêutico, não se pode então aplicar a teoria psicanalítica como tal, embora haja várias tentativas de uma psicologização da teoria psicanalítica. A psicanálise não é também, como Freud sempre fez questão de sustentar, uma visão de mundo ou uma ciência aplicada, mas, sim, uma ciência do psiquismo inconsciente, não tendo a pretensão de resolver os problemas do mundo, mas 
que possa ser capaz de trazer importantes contribuições aos mais variados campos da ciência, na leitura desse mal-estar.

Nesta interlocução, torna-se importante e fundamental também abordar, mesmo que de forma breve, a própria invenção freudiana, já que o esteio dessa interface está no discurso inaugurado por Freud.

A psicanálise nasce da prática; da prática clínica.

Freud, neurologista, clínico, no final do século XIX, com todo o progresso científico tomando corpo, com as revoluções, as descobertas e as quebras de paradigmas no campo médico-científico, coloca-se a escutar seus pacientes. Dá voz à histérica, escuta o funcionamento psíquico que estava para além dos sintomas físicos e fenomenológicos e inaugura a psicanálise a partir da palavra. Neste momento, Freud, ainda entusiasmado com as descobertas de Charcot sobre a hipnose e a sugestão, trabalha juntamente com Joseph Breuer nos "Estudos sobre a Histeria" (1893 - 1895). Neste artigo, faz um verdadeiro trabalho de pesquisa. Investiga, interroga-se, observa, escuta, escreve. Narra seus primeiros casos clínicos, verdadeiros romances, repletos de detalhes, trazendo informações minuciosas sobre os fenômenos sintomáticos e a vida pessoal de seus pacientes. O que está em questão neste primeiro tempo da técnica psicanalítica é seu caráter investigativo, com o objetivo de comprovar as elaborações teóricas e a prática clínica inovadora de Freud. A invenção dessa nova prática clínica, a psicanálise, dá-se a partir da escuta e do desejo de um homem, pesquisador, a frente do seu tempo, que não recua diante dos impasses, dos fracassos e que traz a público seus embaraços, ao assumir a autoria dessa prática nova e original.

O tratamento de Bertha P., conhecido como o famoso caso clínico de Anna O., torna-se, a partir de sua publicação, o caso inaugural, fundador dessa nova prática clínica nomeada posteriormente por Freud de Psicanálise. Anna O. havia sido paciente de Joseph Breuer e o relato clínico de seu tratamento foi escrito por este, alguns anos depois de ter sido interrompido, e somente publicado depois de um longo tempo de espera, por incentivo de Freud. É deste caso que Freud retira o ensinamento, ainda não teorizado, sobre o manejo da transferência, sobre a importância da palavra, sobre o efeito catártico da fala no desaparecimento dos sintomas. Este caso é o marco primordial da escuta clínica psicanalítica. É de Anna O. que Freud toma emprestado os significantes que inauguram a 
psicanálise, como sendo a prática clínica da "cura pela palavra". O relato clínico deste caso nos mostra o trabalho associativo de Anna O., trazendo na sua fala os deslocamentos de significantes ao pedir ao médico que se cale para que ela possa falar. Porém Breuer, diante do novo, do ineditismo dessa nova clínica, embaraça-se na transferência e deixa, segundo Freud, um hiato, uma lacuna, no que se refere ao avanço dessa nova técnica. Breuer recua, dizendo não crer naquilo que ele mesmo havia trabalhado com tanto afinco. Freud, na "História do Movimento Psicanalítico" (1914), revela que foi a partir do que lhe transmitiram seus mestres, Breuer, Charcot e Chrobak, sem que eles próprios soubessem, que ele pode dar um passo além, e ousar na invenção da psicanálise.

Ao assumir a autoria de uma ideia nova e original diante do tratamento da histeria, pois durante muito tempo a neurose foi o único objeto da psicanálise, a invenção freudiana se coloca como uma "ciência auxiliar da psicopatologia", na solução de fenômenos patológicos. Mas, ao ocupar-se do sonho, fenômeno da vida anímica normal, cotidiana, que não se configura como um sintoma patológico, mas sim que faz parte da vida de qualquer homem, a psicanálise afasta-se da psicopatologia e do campo fenomenológico e se coloca como "uma psicologia nova e mais fundamental, indispensável também para a compreensão do normal” (FREUD, 1925, p. 117).

A “Interpretação dos Sonhos" (1900), livro inaugural da prática psicanalítica, passa a despertar interesse não só dos médicos, mas também de leigos literatos e pessoas que estavam fora do círculo científico. Juntamente com um grande interesse, surgem resistências e críticas ferrenhas à nova prática clínica, sendo julgada por muitos como "um produto da fantasia especulativa" de Freud. Um julgamento impreciso, de homens que não possuíam qualquer conhecimento sobre a técnica psicanalítica.

A psicanálise saiu do pequeno círculo de Viena, onde a "Interpretação dos Sonhos"

"mal foi mencionada nas revistas científicas da época, e ganhou o mundo, cruzou oceanos, fez adeptos nas Américas onde também, infelizmente, sofreu algumas atenuações injustificadas, e algo que nada tem a ver com ela cobre-se às vezes com seu nome"(FREUD, 1925, p. 122).

Ao romper as fronteiras do meio médico e despertar o interesse de outros campos, dos leigos, ao tecer colocações e lançar mão da mitologia, da história das religiões, das artes e da literatura, ao promover uma visitação à cultura, disciplinas que pouco têm relação com o saber médico, a psicanálise passa a despertar o interesse para pequenas questões da 
psicopatologia da vida cotidiana. Dessa forma, a partir dessa visitação na cultura, e da incidência da psicanálise nesta, fazendo a leitura do mal-estar que a perpassa, é que desperta o múltiplo interesse na teoria e prática psicanalítica, assim como sua interlocução com outros campos de saber.

Ao privilegiar a fala, a palavra, a psicanálise se inscreve no campo da linguagem, tomando-a também como instrumento. A psicanálise faz uso das leis da linguagem e o funcionamento do inconsciente é definido por Freud a partir dos mecanismos da condensação e do deslocamento, retomados posteriormente por Lacan que define este funcionamento como as figuras de linguagem da metáfora e da metonímia. Tais mecanismos são trabalhados por Freud no livro "Interpretação dos Sonhos" (1900), com o qual, de fato, inscreve a psicanálise no campo científico. Este marco inaugural da obra freudiana e da descoberta do inconsciente é considerado por Lacan como um verdadeiro tratado de linguística, disciplina inaugurada por Ferdinand de Saussure alguns anos depois da publicação do texto freudiano. Lacan afirma que Freud escreve sobre linguística sem o saber.

É Lacan, no seu retorno ao texto freudiano e aos fundamentos da psicanálise, quem põe novamente nos trilhos os conceitos psicanalíticos que haviam sido desviados de maneira tão imprópria pelos pós-freudianos. Lacan inicia sua leitura da psicanálise e seu retorno à Freud já com os recursos da linguística, da topologia e da matemática, com os quais Freud ainda não podia contar. Com sua luz lançada no texto freudiano dá um passo na sustentação dessa invenção e reinventa a psicanálise.

Se é Freud quem descobre o inconsciente, é Lacan quem o define em termos de estrutura de linguagem. Lacan utiliza os conceitos da linguística, forjados por Saussure, subvertendo-os, apontando a primazia do significante sobre o significado e descrevendo o funcionamento do inconsciente a partir dos mecanismos da metáfora e metonímia. $\mathrm{O}$ inconsciente lacaniano, ao escrever-se a partir da topologia, é instaurado no corte preciso que interdita, num só golpe, mãe e filho, fundando o sujeito do inconsciente. A figura topológica da Banda de Moebius ${ }^{7}$, onde não há dentro e fora, mas um fora-dentro, onde há uma relação de continuidade entre esse dentro e fora, define o conceito de inconsciente.

\footnotetext{
${ }^{7}$ A Banda de Moebius é uma figura topológica utilizada por Lacan para fazer uma leitura do inconsciente a partir de dentro-fora. É uma superfície com uma única face e uma única borda, na qual há uma continuidade entre o dentro e o fora.
} 
Freud, sem o recurso da topologia, aponta no texto “O Estranho" (1919) esse fora-dentro, esse estranho que, ao mesmo tempo, é tão familiar, pelas relações que guarda com o recalcado. $\mathrm{O}$ inconsciente não está nas profundezas, como a metáfora do iceberg utilizada pelos pós-freudianos, mas, sim, na superfície, na ponta da língua, escorrendo por entre os dedos. O inconsciente se manifesta por suas formações, nos atos falhos, nos chistes, nos sonhos e sintomas. Com o recurso da linguística, Lacan afirma que "foi Freud quem nos revelou a incidência de um saber tal que, ao se subtrair à consciência, nem por isso deixa de se denotar estruturado como uma linguagem" (LACAN, 1970, p. 423). E assim define a descoberta freudiana:

\footnotetext{
"Sua descoberta foi ter soletrado, escandido o inconsciente, e desafio a dizerem que isto possa ser outra coisa que não a observação de que há um saber perfeitamente articulado, pela qual, falando propriamente, nenhum sujeito é responsável. Quando de repente um sujeito chega a encontrar, a tocar esse saber que não esperava, ele fica, pois bem, ele que fala, fica bastante desconcertado.

Era o primeiro achado. Freud disse aos sujeitos - Falem, falem, façam como a histérica, vamos ver qual é o saber que encontram e a maneira pela qual são aspirados por ele, ou então, pelo contrário, a maneira pela qual o repelem, vamos ver o que acontece. E isto o conduziu necessariamente a essa descoberta (...)" (LACAN, 1969/70, p. 81).
}

O inconsciente porta um saber; um saber subtraído do consciente, que não se sabe como tal. Esta estrutura de linguagem, esse saber que não se sabe, esse saber que advém do falar, articulado ao discurso, esse saber que emerge na cadeia significante, está em Freud, já em 1895, na escrita do caso clínico de Elizabeth von R, onde aparecem nas "cadeias de reminiscências", os deslocamentos significantes, como tendência a justificar as "dores" da paciente. Esse caso exemplar da prática clínica de Freud traz articulações quanto ao gozo e à estrutura, à transferência e à resistência que sustentam e permitem o tratamento, o infantil, a fantasia e o recalcado, que se enodam na constituição da neurose.

A partir de 1920, ao introduzir em sua obra o conceito de castração e suas articulações sobre o período pré edípico, dando um passo além do Complexo de Édipo (o qual trabalharemos no próximo ensaio), Freud tece considerações sobre o mecanismo da verleugnung, esse desmentido estrutural ${ }^{8}$, que instaura uma cisão no eu que nunca mais

\footnotetext{
${ }^{8}$ A noção de estrutura é posta em campo por Lacan, embora já estivesse presente em Freud não nomeada dessa maneira. Já nos seus primeiros artigos vemos essa noção sendo delineada. Há mecanismos constitucionais do ser falante, do sujeito, que quando falham deixam marcas e efeitos na estrutura. São três as estruturas clínicas colocadas por Lacan a partir de seu retorno à obra freudiana: neurose, psicose e perversão.
} 
cicatrizará; desmentido que se refere ao saber sobre a castração, ao saber sobre a falta, sobre o sexual. Assim, inconsciente e saber se articulam e o inconsciente se coloca como "o ponto nodal de um saber falho" (LACAN, 1968-69, p. 265). E o saber que, para nós, está em questão é este saber inconsciente. E assim Lacan define de forma tão poética o inconsciente em sua relação com o saber: "o saber é coisa que se diz, que é dita. Pois bem, o saber fala por conta própria - eis o inconsciente" (1969-70, p. 73). Esse saber que se debulha vai se desfiando por conta própria na cadeia significante.

Porém é Lacan quem forjará o conceito de sujeito dividido, cindido, submetido à barra do recalque originário que funda o sujeito. Esse sujeito instaurado pela leitura lacaniana se constitui no campo do Outro, é atravessado pela linguagem, é um sujeito falado antes mesmo do seu nascimento, que traz as marcas significantes da sua história a partir de uma herança simbólica. “(..) para-além dessa fala, é toda a estrutura da linguagem que a
experiência psicanalítica descobre no inconsciente. (...) Pela razão
primeira de que a linguagem, com sua estrutura, preexiste à entrada de
cada sujeito num momento de seu desenvolvimento mental. (...) Também
o sujeito, se pode parecer servo da linguagem, o é ainda mais de um
discurso em cujo movimento universal seu lugar já está inscrito em seu
nascimento, nem que seja sob a forma de seu nome próprio” (LACAN,
1998, p. 498).

Se a linguagem é o que instaura a civilização, fazendo a marca divisória entre natureza e cultura, ela não é objeto exclusivo da linguística. A linguagem está na cultura, constituindo-se como a lei primordial para o ser falante, lei simbólica, pois para estar inscrito na linguagem é preciso estar submetido à interdição universal do incesto. É a inscrição da linguagem que barra de partida o gozo incestuoso. A psicanálise privilegia o significante em detrimento do significado, a enunciação em detrimento do enunciado, o dizer em detrimento do dito. Para a psicanálise, há sempre algo que escapa ao sujeito, que está para além do dito, do enunciado, do significado. A psicanálise está ancorada no impossível, na incompletude, levando em conta o mal-entendido que permeia o engano da comunicação e sustentando que "o efeito que se propaga não é de comunicação da fala, mas de deslocamento do discurso" (LACAN, 1970, p. 405).

A verleugnung é o mecanismo por excelência da perversão. O desmentido está articulado ao conceito de castração, ou seja, à recusa dessa realidade, da ausência de pênis na mãe. Podemos recorrer aos textos freudianos do "Fetichismo" e "A cisão do eu no processo de defesa" para termos maior clareza sobre esse mecanismo. 
Retomemos a questão da transferência. Nesta nova prática clínica, um novo fundamento é escutado, a saber, a transferência. É diante da transferência que Breuer recua e que Freud pode dar um passo, fazendo avançar sua teoria.

Este conceito é apontado por Lacan como um dos quatro conceitos fundamentais da psicanálise. Por fundamental entendemos aquilo que sustenta, que está na base, aquilo que é "condição necessária à possibilidade da análise". Sendo assim, toda análise, seja ela na intensão ou extensão ${ }^{9}$, tem seu princípio básico na transferência. A transferência é então a mola mestra de todo tratamento analítico. Contudo, não é privilégio da análise, nem tampouco um produto desta. A transferência, como foi dito no ensaio anterior, é um produto da neurose, que permeia as relações humanas e os laços sociais. Ela não aparece mais intensa ou desenfreada na análise do que se manifesta na vida cotidiana das relações sociais. O que fez a psicanálise foi recolher e revelar esse ponto da transferência e fazer dele sua experiência. $\mathrm{Na}$ análise, a transferência é escutada, trabalhada, manejada, permitindo a construção do paciente e a elaboração de suas relações. O lugar dado à transferência, na análise, exige que o analista, frente a isso que lhe é dirigido, encare as coisas de um ponto de vista completamente diferente. Esta é uma indicação precisa e pontual de Freud, da qual ele também não cede. Indicação ratificada por Lacan ao sustentar que para os analistas, mesmo os mais experientes, a experiência da transferência traz, cada vez, a cada análise, a cada caso, uma nova surpresa. Apesar de ser a transferência marcada por certo número de artifício, não é razão para pensarmos, como afirma Lacan, que a transferência seja um artifício.

"Proteger-se atrás da motivação artificial da transferência, por pensar que afinal de contas trata-se de um artifício, é se colocar ao abrigo de alguma coisa que podemos compreender, pode parecer pesada porque como Freud não deixava de encarar: não há nenhuma diferença entre a transferência e o amor" (LACAN, 1972).

Em 1915, ao versar sobre o "amor de transferência" e as implicações do enamoramento do paciente pelo médico no tratamento psicanalítico, tema espinhoso, situação embaraçosa, mas que, segundo Freud, precisa sair da discrição e ser tratada com seriedade e rigor, ele nos aponta o temor de todo principiante em psicanálise com as interpretações e as reproduções do recalcado de seus pacientes. Porém o verdadeiro

\footnotetext{
${ }^{9}$ Ver nota de rodapé referente a esses termos no capítulo anterior.
} 
embaraço com que se deparam, principiantes ou não, é com o manejo da transferência. Ou seja, com esse amor que lhes é dirigido. Porém, como nos indica Lacan, "a questão do amor é assim ligada à do saber" (1972/73, p. 122). Lacan dedica-se a esse amor ao saber ao trabalhar o seu Seminário "A transferência" (1960/61), trazendo como pano de fundo para toda essa elaboração "O Banquete”, de Platão. Neste primeiro tempo de suas articulações quanto à transferência, já está o amor, um amor ao saber; amor dirigido ao Outro, a um Outro que se supõe um saber sobre a verdade, sobre esse amor. E por isso Lacan escolhe "O Banquete" para dar partida às suas articulações quanto à transferência, pois " $O$ Banquete" "oculta em si algo de absolutamente radical quanto a essa mola do amor" (LACAN, 1960/61, p. 170). E Lacan também define o amor como sendo "a mais profunda, a mais radical, a mais misteriosa das relações entre os sujeitos" (idem, p. 169).

\begin{abstract}
"é a questão formulada ao Outro, quanto ao que ele pode nos dar e ao que tem para nos responder, que se liga o amor como tal. Não que o amor seja idêntico a cada uma das demandas com as quais o assediamos, mas ele se situa no mais-além dessa demanda, na medida em que o Outro possa ou não nos responder como última presença" (LACAN, 1960/61, p. 172).
\end{abstract}

Lacan inicia seu seminário sobre "A transferência" colocando o amor como ponto de partida. "No começo era o amor" (LACAN, 1960-61, p. 11), parafraseando a fala bíblica onde se diz que "No começo era o Verbo". Se no começo da experiência psicanalítica está o amor, é este que inaugura a prática da palavra, do verbo, tendo a transferência como núcleo dessa experiência. Nesse começo, espinhoso e árduo, para que a palavra possa ser articulada no discurso, é imprescindível que esteja referida ao amor, ou seja, sob transferência.

Se no princípio está o amor, no princípio está a transferência. Por isso, a indicação tão pontual e rigorosa de Freud de que o analista principiante deve temer e estar atento ao seu manejo. Mas, se a transferência é produto da neurose, permeia as relações sociais e não se restringe à prática psicanalítica, ela também se apresenta de uma forma peculiar na prática analítica. Não se trata de transferências distintas ou modalidades diferentes de transferência. A peculiaridade na psicanálise é que o analista faz uso dessa transferência, desse amor, no trabalho analítico e a prática psicanalítica se configura dessa maneira e, a partir dela, como uma prática da transferência. 
Todavia, no tratamento analítico, "a transferência, a mais poderosa alavanca do êxito, se transforma na arma mais forte da resistência" (FREUD, 1958[1912], p. 225/226). E Freud nos coloca a pergunta "por que a transferência se nos opõe, como resistência, no tratamento psicanalítico?" (idem, p. 226).

"É aí que a análise incita a esse lembrete de que não se conhece amor sem ódio" (LACAN, 1972/73, p. 122). Transferência e resistência são faces da mesma moeda e caminham lado a lado no tratamento analítico. Assim como amor e ódio, ou "amódio", como fala Lacan, para trazer para o campo desse fenômeno o ponto estrutural da ambivalência, ponto que coloca o amor de transferência numa posição bastante paradoxal. Essa ambivalência tão primária nas relações parentais do sujeito infantil aparece aí, reeditada nesse "amódio", nessa enamoração feita de ódio e de amor, onde a psicanálise inscreve sua experiência. Assim, a resistência também surge no tratamento travestida de transferência positiva, recoberta por esse enamoramento e também se manifesta em forma de paixão. A paixão não correspondida faz surgir a desobediência, o capricho, o rechaço, a hostilidade. Esse amor que surge na transferência não é novo e não traz nada de inédito. É apenas uma repetição de reações e afetos infantis. Sendo assim, a transferência guarda uma grande relação com o passado. É um amor que porta a ambivalência, que traz não só as representações libidinais conscientes, mas também as inconscientes. Esse amor é dirigido ao analista e este é incluído nas séries psíquicas dos protótipos infantis. E o analista, sendo objeto da transferência, se empresta ali, fazendo semblante para esses clichês estereotípicos. E assim, a análise vai ensinar ao sujeito aquilo que lhe falta, e este aprenderá amando, ou seja, na transferência. A partir da reedição desse passado, da reedição dessas relações infantis, o sujeito fabrica e constrói na transferência. Constrói sua ficção, seu romance familiar, reconstrói sua cena fantasmática, sua relação edípica, fazendo dela sua realidade psíquica, sua verdade histórica.

\footnotetext{
"A partir daí começa a pergunta: como com efeito, uma situação de artifício pode determinar uma ordem de sentimentos que parece uma ordem tão elevada na ordem natural quanto o amor, eu devo acrescentar, pois a transferência não tem somente esta forma, tem também a do ódio. Mas se a análise demonstrou alguma coisa, foi a profunda e estreita ligação entre o amor e o ódio" (LACAN, 1972).
}

Freud é preciso ao apontar o manejo da transferência como operador na direção do tratamento. Não cabe ao analista responder à demanda de amor e reconhecimento, nem 
mesmo vestir-se com o moralismo e abrir mão do seu trabalho. Cabe ao analista sustentarse na ética, velar pelo manejo da transferência e escutar a demanda, trabalhar a partir dela para que possa advir o desejo. E ao educador? Caberia a ele responder à demanda de amor? Também não cabe ao educador essa posição, embora este seja o ideal que permeia a educação e a formação dos educadores, o ideal do magistério como um dom, do ensinar tendo como base o amor. Cabe ao educador, na sua função também, dar um lugar ao manejo da transferência.

Se a transferência é algo que permeia as relações sociais, ou seja, se ela é um produto da neurose, se as relações se desenrolam no terreno dos fenômenos da transferência, podemos trazer esse fenômeno para o campo que nos interessa nesse ensaio, o campo educacional. A escuta que a psicanálise pode fazer da educação tem a exigência ética de dar um lugar para o manejo da transferência. É uma exigência para ambos os lados dessa interlocução. A ética da psicanálise, ética que privilegia o desejo, não vai sem a escuta atenta e o manejo da transferência. Não há ética psicanalítica se não está em campo a transferência. A educação não precisa, nem mesmo deve, apropriar-se da ética da psicanálise e fazer dessa a sua experiência. De forma alguma estamos aqui propondo uma substituição de valores e de lugares. Freud sempre foi bem claro nesse aspecto, apontado com muito rigor que Educação e Psicanálise são campos distintos e que um não pode nem deve ser substituído pelo outro. O que a psicanálise traz no cerne de seu discurso, esse discurso inédito que possibilita uma subversão no discurso do mestre e uma leitura dos demais discursos instalados na cultura, é justamente a impossibilidade. Lacan chamará tal ponto de falta como objeto $\mathrm{a}^{10}$, colocando-o no lugar diretor desse discurso. É isso que norteia a ética da psicanálise. A educação está sustentada, por excelência, no discurso do mestre, e nesses tempos contemporâneos podemos até mesmo dizer que se pauta no discurso universitário, discurso onde o saber (S2) está no lugar diretor. A aposta que se faz aqui, nesta interlocução, é que o discurso analítico, ao atravessar o campo educacional,

\footnotetext{
${ }^{10}$ Conceito forjado por Lacan a partir daquilo que Freud elabora da noção de objeto na psicanálise, a partir do jogo da repetição e do objeto perdido. O objeto a, segundo Lacan, é somente uma letra, mas sem dúvida parece ser alguma coisa. O objeto a está relacionado ao conceito de pulsão, às pulsões parciais. E só há ideia do objeto a a partir de seus estilhaços. Pode-se falar do objeto a também como vazio e isso remete à questão do gozo. Outra forma de elaborar sobre o objeto a é sob o aspecto de resto, onde ao mesmo tempo é função e resíduo. Lacan situa o objeto a no centro do nó borromeano, na interseção entre Real, Simbólico e Imaginário. E este também ocupa o lugar diretor no discurso analítico. Lacan define o objeto a como sendo "o efeito maior da linguagem" e esse efeito é produzir gozo e resíduos de gozo (KAUFMANN, 1996, p. 377).
} 
produza como efeito uma possível torção na posição daqueles que se debruçam sobre essa árdua tarefa de educar; permitindo uma não cristalização nesse lugar de mestre, de saber, mas, sim, uma circulação, sendo possível também ocupar um lugar de resto, furado, barrado na função de educar, sustentando dessa forma a educação como uma prática que toca o impossível, o real. Se há uma circulação discursiva e não uma instalação num único discurso, a passagem pelo discurso analítico não será sem consequências. E num giro de 360 graus, que leva novamente ao ponto de partida, ao discurso que, por excelência, sustenta a prática educacional, não se chega da mesma maneira, sem os efeitos que o discurso analítico comporta. Trataremos de forma mais detalhada sobre os quatro discursos no quarto ensaio desta dissertação.

Enfim, se estamos aqui falando da escuta que a psicanálise pode fazer da educação, é preciso que situemos que tal escuta está pautada nessa novidade que o discurso analítico traz, ou seja, nessa possibilidade de leitura do mal-estar que perpassa a cultura. É esse o lugar do discurso psicanalítico na interlocução, poder fazer uma leitura do mal-estar. Tal leitura também se estende ao campo da educação, ao mal-estar que a permeia, àquilo que nela fracassa. Pudemos tratar desse ponto no primeiro ensaio, onde apontamos que a psicanálise, ou seja, o discurso psicanalítico teria também algo a contribuir com o campo educacional. A disparidade entre o êxito almejado e o fracasso encontrado pela educação revela esse mal-estar. O fracasso é o próprio mal-estar na forma que se apresenta no campo educacional e que é, a todo custo, rechaçado pela educação.

A exigência ética que se coloca aqui ao campo educacional no que se refere ao manejo da transferência trata-se de uma aposta. Aposta de que a partir dessa escuta, na qual serão transmitidos os significantes do discurso psicanalítico, a educação possa assumir uma posição outra, atravessada por essa ética do desejo, porém sem se apropriar dessa ética e fazer dela sua causa. A aposta que se faz é de que haja aí, nessa interlocução e nesse atravessamento pelo discurso psicanalítico, um efeito de transmissão, possibilitando uma leitura outra desse mal-estar e não uma tentativa incessante e desenfreada de eliminá-lo, de escamoteá-lo, de tirá-lo da cena educacional. Um atravessamento de fato pelo discurso analítico, que tenha como efeito uma mudança subjetiva de posição, que traga a convicção do inconsciente, isso Freud, Lacan e a prática clínica nos deixa claro que só há pela passagem pelo divã, pela experiência na carne da realidade do inconsciente. Porém não é 
isso que estamos aqui propondo, que todo educador passe pela experiência analítica ou que para que se possa educar seja preciso se submeter à análise, como uma condição básica à função de educar. Apontar a questão dessa forma seria cair num grande engodo e promover um grande desvio do texto psicanalítico. Para que haja interlocução, não há a exigência de que todos passem pela experiência analítica, embora dessa condição não seja possível abrir mão quando se trata de sustentar a convicção do inconsciente. Se um ou outro educador, nessa interlocução, for fisgado por um significante e a partir daí fizer uma questão que o leve a uma demanda de análise é outra coisa. A escuta que a psicanálise poderá fazer da educação, a partir daqueles que estão nessa função, ou seja, os educadores, é uma escuta atravessada por seu discurso, seus significantes e sua ética, porém não é uma escuta que pretende uma direção de cura. Isso sim só se dá no divã.

Aqui podemos introduzir duas novas questões importantes quanto à escuta que a psicanálise pode fazer da educação. Questões que nortearam o percurso aqui trilhado, auxiliando-nos a não desviarmos do ponto fundamental dessa interlocução e não cairmos no equívoco da demanda de saber. Se a psicanálise se coloca a escutar a educação, tomando a escuta, flutuante, como seu instrumento, sendo o contraponto da regra fundamental que norteia essa prática, a associação livre, estaríamos então às voltas com uma transferência da educação dirigida ao campo psicanalítico? A transferência de que se trata aqui, nessa interlocução, seria então uma transferência ao texto psicanalítico, aos significantes novos que o discurso psicanalítico inaugura? Como poderíamos então pensar aqui a transferência? Se há escuta, há transferência. E podemos dizer também que se há transferência é preciso haver escuta. A escuta é aqui uma aposta, aposta de que a partir dela algum efeito possa ter na posição daqueles que estão imersos na função de educar.

É preciso estar atento nesse ponto para não cairmos no engano de pensar que a transferência que perpassa a interlocução entre psicanálise e educação é unilateral. Freud nos alerta para a contratransferência do analista no tratamento e Lacan trabalha incansavelmente tal questão. Dirá que aquilo que aparece do lado do analista se apresenta como contratransferência. Ou seja, "tudo aquilo que, no analista, representa seu inconsciente enquanto, digamos, não analisado, foi considerado como nocivo para sua função e sua operação de analista" (LACAN, 1960-61, p. 183). 
“(...) a contra-transferência de que se trata - (...) - é feita de sentimentos experimentados pelo analista na análise, e que são determinados a cada instante por suas relações com o analisado" (Idem, p. 190).

Porém no trabalho analítico, é preciso que o analista se apague, havendo ali apenas um sujeito, o sujeito do inconsciente do analisante. Mas, quando se trata de uma interlocução, da psicanálise na sua extensão, não estamos mais falando do analista na direção da cura. Ali, na extensão, para que haja ensino e transmissão, é preciso que o analista também pague com sua palavra, ou seja, que se coloque a falar. A psicanálise, o campo psicanalítico a partir dos analistas que se colocam na transmissão e na interlocução, só pode escutar a educação, o campo educacional, na figura daqueles que falam em seu nome, daqueles que se colocam na árdua tarefa de educar e que têm algo a dizer e a questionar sobre sua prática, ou seja, os educadores. Sendo assim, não queremos aqui dizer que haja uma transferência da educação dirigida à psicanálise. A aposta que se faz é que, a partir dessa interlocução, possa haver um endereçamento ao texto psicanalítico, aos seus significantes, ao seu discurso e dessa forma algo possa ser transmitido produzindo efeitos na posição dos educadores. Ou seja, o efeito da escuta que a psicanálise pode fazer da educação, dando um lugar para a transferência, incide fundamentalmente na posição do educador.

Freud discorre sobre a presença da transferência no campo educacional ou, melhor dizendo, na relação de aprendizagem, ao trabalhar o texto já citado "Algumas considerações sobre a psicologia do escolar" (1914). O professor/educador, assim como o analista, é incluído pelo aluno nas séries psíquicas dos seus protótipos infantis, é alvo de transferência, de amor e rechaço, de admiração e hostilidade. É objeto de identificação e cabe também ao professor/educador dar um lugar à transferência na sua prática, manejá-la, além de escutar a demanda trazida pelo aluno. É a partir da demanda que o professor/educador precisa trabalhar, porém sem respondê-la prontamente, possibilitando assim que o desejo de saber seja despertado e que o aluno possa se apropriar e construir um novo saber. Este seria o efeito de um trabalho no campo educacional sob a luz da transferência, ou atento a esse fenômeno.

Também cabe ao professor/educador escutar o funcionamento e não cair no engano da admiração ou do rechaço pela sua pessoa, mas, sim, atentar-se para aquilo que ele representa. Seria possível transferir para o campo da educação a recomendação de Freud e 
dizer que também o professor/educador precisa encarar as coisas de um ponto de vista diferente? Como poderia o professor/educador encarar as coisas de um ponto de vista diferente? Talvez podendo se atentar para o fenômeno e o manejo da transferência. Estar avisado de que o amor que lhe é dirigido não se deve aos seus belos olhos nem à sua simpatia, que a hostilidade e o rechaço não se dá porque ele é chato ou sua disciplina desinteressante. Mas, sim, poder colocar-se nesse lugar ao qual é dirigida toda essa gama de afetos de uma forma menos pessoal. Não cair no engano do artifício nem mesmo no ideal de comunicação. Como nos diz Lacan, a comunicação é falha, é um engodo. O que nos interessa são os deslocamentos de discurso. Estar avisado e atento a tal fenômeno não significa ser comunicado da existência dele, mas, sim, poder colocar-se nessa função a partir dele, ou seja, a partir do lugar ocupado na transferência. Assim como Freud nos indica que é somente sob transferência que um sonho pode ser analisado ou uma interpretação feita, é somente sob transferência que um saber pode ser construído. Bastaria então estar atento e avisado? Ter conhecimento desse fenômeno da transferência? Freud traz esse aviso como uma orientação aos analistas, sem a ilusão de que, por saber disso, por ter estudado sobre tal fenômeno ou mesmo por ter sido esclarecido de sua existência, o analista não irá se embaraçar justamente aí, no manejo da transferência. Não basta ao educador estar atento e avisado, porém estar atento e avisado, ter um certo conhecimento disso, abre a possibilidade de que uma questão possa ser levantada quanto à posição e à função de educar. Essa é a aposta.

A colocação de Freud quanto ao lugar do tratamento psicanalítico e a inutilidade do furor sanandi, assim como de quaisquer outros fanatismos para a sociedade humana, também serve e se aplica à educação. Quanto à educação não se trata de um furor sanandi, mas de um também inútil furor pela aprendizagem, pelo fazer-se compreender. Esse ideal de aprendizagem, de compreensão, de aquisição de conteúdos, essa ilusão de um modelo padrão e de uma aprendizagem plena, satisfatória, rechaça completamente a escuta e o lugar da transferência no processo educativo. Rechaça o desejo. Rechaçar a transferência nesse processo, apoiar-se no ensino, nos métodos e técnicas, na aquisição de um dado conhecimento, é também rechaçar o desejo, a diferença e ancorar-se na demanda. Havendo um lugar para a transferência, para a escuta da posição do educador, atravessada pelos significantes da psicanálise, haverá também um lugar para o rigor da ética do desejo, como 
diretora do ato educativo; não na tentativa de promover o bem da educação, o furor da aprendizagem plena, mas sim na aposta de instaurar a construção de um saber pela via do desejo. Este é um grande desafio, tendo em vista que este é o ideal que permeia a educação. A aposta que se faz nessa interlocução é a de que, a partir dela, um furo seja feito possibilitando a queda desse ideal de um ensino e aprendizagem plenos; ideal no qual a Educação está imersa.

Este é o nó dessa interlocução, quando a tomamos no sentido da educação formal. Como seria possível pensar numa prática educacional como uma prática da transferência, atravessada pelos significantes da psicanálise, quando o modelo de escola que hoje vigora é esse modelo cristalizado no imaginário e na idealização de uma aprendizagem plena? Como pensar uma prática da transferência nesse modelo de escola no qual a avaliação está no comando e o discurso universitário impera, tendo o saber no lugar diretor e sendo este tomado como meio de gozo, como saber a acumular? Neste modelo de escola, de educação, que hoje vigora, esse modelo imaginário, ideal, inflado, no qual o saber domina a cena e o sujeito é um mero repetidor, no qual pouco se coloca algo próprio, um impasse está colocado. Pois nesse modelo não há furo. Se um furo aparece, logo é tamponado por algo mais moderno, mais eficaz, mais satisfatório, mais fascinante. Mas o furo insiste. O ineducável insiste.

Nesse modelo contemporâneo da educação, o discurso universitário articula-se ao discurso capitalista e a escola estrutura-se como uma empresa, nos moldes capitalistas, pretendendo atender às exigências do mercado, promovendo uma tentativa incessante de responder às demandas e tamponar a falta, ficando a questão do desejo completamente comprometida, sendo privilegiado apenas o consumo e o acúmulo do saber. A escola, lugar formal onde se veicula a educação, enquadrada nesse discurso capitalista, põe-se a formar mão de obra e não gente. Fala-se em formar cidadãos, porém para enquadrá-los no mercado de trabalho. Primeiro, é preciso que se forme gente para que posteriormente se possa formar trabalhadores. Nessa lógica contemporânea, na qual discurso universitário e discurso capitalista se associam, temos uma escola, uma educação que não oferece a possibilidade de subjetivação. E o saber entra nessa lógica como mais um produto a ser consumido e acumulado e o sujeito/aluno não pode comparecer com algo próprio, com uma produção ou construção na qual o estilo próprio possa estar colocado, sustentado pelo desejo, ou seja, na 
qual possa aparecer como sujeito, subjetivado. Essa lógica traz na sua estrutura um desmentido da castração, da falta, da impossibilidade, da divisão do sujeito, impedindo que uma questão possa ser sustentada, que algum desejo possa estar presente. Uma escola que não tenha uma causa, um desejo de educar não pode subjetivar ninguém. Mais uma vez, é preciso enfatizar aqui que não se trata de uma substituição ou uma transposição daquilo que é do campo da psicanálise para o campo da educação. Escutar e servir de causa ao desejo é função do analista e não cabe à educação essa função. Caso coubesse, estaríamos falando novamente de um ideal de educação pelo prisma da psicanálise. E quando está em causa o discurso analítico, estamos falando justamente do avesso, da queda desse ideal e da ilusão da satisfação plena, de um saber completo e total. Porém, para que a educação possa subjetivar, e essa também é sua função, é preciso que esteja em campo o desejo, o desejo de educar.

Não está em questão aqui uma mudança de paradigmas do campo educacional. A educação sempre terá seus ideais, suas premissas, seus métodos. Mais uma vez, o que se pretende nessa interlocução é fazer uma aposta. A psicanálise não substituirá nunca, em hipótese alguma, a educação. Nem a tornará melhor. A aposta que se faz é apenas na possibilidade de um atravessamento pelo discurso psicanalítico, não sem efeitos nesse campo. Aposta na possibilidade de que, a partir desse atravessamento, um novo olhar na educação seja lançado e que se possa fazer uma nova escuta desse campo. Um olhar e uma escuta menos imaginários, menos ilusórios, menos idealizantes, menos classificatórios e quantitativos; um olhar e uma escuta que possam contar a diferença e a particularidade e que possam privilegiar aquilo que é próprio de cada sujeito.

Nessa lógica onde o que está em questão é o um + um + um + um ... fazendo um todo, uma massa numérica de aprovação, de aproveitamento satisfatório, de qualidade, de competência, o um do sujeito fica de fora, não há subjetivação. Este é o ponto mais importante que a educação pode recolher da psicanálise, a saber, tomar o sujeito na sua singularidade, no um a um, no caso a caso.

Neste texto citado acima, de 1914, “Algumas reflexões sobre psicologia do escolar”, Freud traz para a ordem do dia a questão da relação do professor com o aluno, pautada na transferência. Porém estamos aqui apontando dois caminhos que se entrelaçam nos meandros desse fenômeno. A relação transferencial necessária nessa interlocução entre 
psicanálise e educação, e como esse fenômeno, esse conceito, opera também na educação, na relação professor/aluno, naquele que se põe a ensinar, podendo transmitir um legado. Já vimos que sem transferência não há interlocução. Sem esse atravessamento pelo texto psicanalítico, sem ser causado pelos significantes que o perpassam, sem os fundamentos que o sustentam, não há interlocução. Sendo assim, podemos afirmar que sem transferência também não há ensino, não há transmissão. É preciso que haja um endereçamento do campo educacional à psicanálise para que seja possível tal interlocução e para que, nessa interlocução, haja um efeito de transmissão. Assim como é fundamental que haja um endereçamento do aluno ao professor para que esse possa se colocar a ensinar e para que o aluno possa, de alguma maneira, aprender. Porém este endereçamento é uma grande dificuldade com a qual esbarramos nessa interlocução.

Há uma relação estreita entre o amor, a transferência e o desejo. Tal relação torna-se ainda mais tênue ao apontar a questão do amor ligada ao saber.

\footnotetext{
"Se considerarmos a transferência - apesar da insistência em pensá-la como a relação afetiva que o analisante estabelece com seu analista - se a consideramos como uma estrutura significante, em que um saber trabalha na própria divisão do sujeito, estaremos em condições de dar uma resposta mais satisfatória à questão do ensino da psicanálise. Esse saber só trabalha à condição de que um sujeito seja suposto sustentá-lo. Para que um sonho venha a ser decifrado, um ato falho lido, uma lembrança encobridora reconstruída, é necessário um analista em função de sujeito suposto" (VIDAL, 2001, p. 50).
}

Assim, podemos introduzir e, de forma bastante breve, tentar abordar o que Lacan traz de novidade no campo da transferência, ou seja, a noção de Sujeito suposto Saber. É nesse conceito, a partir daquilo que Lacan pode ler em Platão, no seu " O Banquete" que se articula a questão do amor ligada ao saber. E é também nesse conceito que se articula, como nos aponta Lacan em 1964, na Proposição de 9 de outubro, "tudo o que se relaciona com a transferência" (p. 33). Como foi dito anteriormente ao abordarmos "O Banquete", o amor dirigido ao Outro é um amor ao saber. Sendo assim, se há sujeito suposto saber, se há suposição de saber no Outro, há transferência.

O sujeito é suposto. Suposto pelo significante que o representa para outro significante e assim se desvanece. É a partir disso, do que é suposto, que Lacan escreve o matema da transferência. O saber que se articula aqui é o saber inconsciente. Sem ele não há possibilidade de transferência. E desse saber suposto, não se sabe nada, como nos indica 
Lacan. É o analista ali, oferecendo-se como objeto dessa transferência, fazendo semblante de objeto, como causa do desejo que faça advir o saber inconsciente. Assim, "o não-sabido se ordena como moldura do saber" (LACAN, 1964, p. 34).

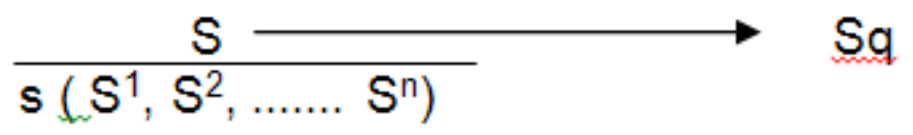

Na escrita desse matema, Lacan aponta que o S, significante da transferência se articula a um significante “qualquer”. Porém por ser qualquer, não é qualquer um. É eleito não pelo saber que ele comporta, pelo nome que ele carrega, mas, simplesmente, por estar na cadeia. Sob a barra está o sujeito (s) que resulta dessa relação significante, implicando o saber que aparece no parêntese. Esse saber está articulado na cadeia significante, saber inconsciente.

\begin{abstract}
"A questão é, primeiro, para cada sujeito, de onde ele se baliza para dirigir-se ao sujeito suposto saber. De cada vez que essa função pode ser, para o sujeito, encarnada em quem quer que seja, analista ou não, resulta da definição que venha de lhes dar que a transferência já está então fundada" (LACAN, 1964, p. 226).
\end{abstract}

Dessa forma, há a suposição que o Outro sabe. É a partir dessa suposição que um sujeito se dirige a um analista. É a partir dessa suposição que um analista pode se oferecer como objeto nessa prática da transferência. É a partir dessa suposição de saber que um trabalho e uma construção podem se dar, e que o sujeito pode tomar as rédeas de seu desejo.

E mais uma vez fazendo uma analogia nessa interlocução que nos interessa, é somente a partir dessa suposição de saber que também pode haver transmissão, que um ensino pode operar e produzir efeitos. Sendo o professor/educador também objeto de transferência, sujeito e saber são aí também supostos pelo significante, um significante qualquer. E aqui também não é de um saber referencial que se trata, mas sim do saber inconsciente, do saber-fazer, do saber que se impõe ao sustentar uma posição ética diante do ato de educar. Também um saber não-sabido que se ordena como moldura do saber, permitindo a construção de um saber próprio pelo aluno.

Tentemos então nos aproximar da relação professor/aluno à luz do fenômeno da transferência.

"O passo de Freud que possibilitou a invenção do inconsciente foi não enganar-se com as declarações de amor do romance das 
histéricas, sabendo que exercia uma função, e não estava aí implicado nem como pessoa, nem como sujeito" (VIDAL, 2001, p. 51).

Ou seja, assim como o analista na direção da cura, o professor/educador exerce uma função e ocupa ali, nesse exercício, nessa prática, um lugar. Nesta função o professor/educador não está implicado como pessoa, mas estaria sim como sujeito, posto que se põe a ensinar. Parece algo confuso, mas aqui, na educação, trata-se de uma prática na qual o ensino está presente, é peça chave, é objeto de trabalho.

Não estamos transpondo o setting analítico para o campo educacional. Freud também nos atentou quanto a isso, ou seja, quanto àquilo que é função da análise e àquilo que cabe ao campo da educação. Embora estejamos aqui apontando a presença do fenômeno da transferência na relação professor/aluno, não há a pretensão, nem mesmo a aposta de que a prática educativa seja uma prática da transferência, como a análise. A aposta é apenas que tal transferência possa ser escutada e que o educador possa estar atento a ela no exercício de sua função. Aposta de que o educador possa, de certa maneira, fazer uso dessa transferência, como já apontamos anteriormente, encarando as coisas de um ponto de vista diferente. Pois, assim como o analista, numa pequena analogia, o educador se empresta como objeto da transferência do aluno. A lógica da educação está na relação de ensino e aprendizagem. Afirmamos, a partir do discurso e do texto psicanalítico, que só há ensino e transmissão se houver transferência e que só há transferência se houver suposição de saber no Outro. Sendo assim, para que um professor possa se colocar a ensinar, a transmitir um legado e para que um aluno se disponha a aprender e apreender os significantes dessa transmissão, é preciso que sujeito e saber sejam supostos para que haja transferência.

Maria Cristina Kupfer (2009), em seu texto "Amor e Saber: a psicanálise da relação entre professor e aluno", discute tal relação à luz da transferência. Tomemos aqui o que a autora comenta sobre o interesse que o professor desperta no seu ensino.

\footnotetext{
"A ideia da necessidade de o professor criar motivações em sala de aula, de provocar o interesse dos alunos, não faz sentido nesse contexto. $\mathrm{O}$ interesse do professor, que se transmite ao aluno, é o interesse da relação com seu objeto de desejo. $\mathrm{O}$ que o professor deixa transparecer ao aluno não é que o seu objeto é "interessante" e, sim, a intensidade da relação construída com aquele objeto - uma intensidade capaz de despertar no aluno o interesse em ter uma relação parecida" (KUPFER, 2009, p. 27).
} 
Ou seja, o professor não transmite o quanto a disciplina ensinada por ele é legal, importante ou fundamental. Não ensina aos alunos a gostar desse ou daquele conteúdo, mas, sim, transmite, veicula a partir do que ele ensina, o quanto é causado em seu desejo pela função que exerce. Na transmissão, não é o saber referencial que está em causa, mas, sim, o saber textual, saber referido ao texto inconsciente. É esse saber que se articulará em discurso e poderá ser transmitido. Tal fala de Kupfer faz eco no que escreve Freud quanto ao que mais nos marcou de nossas vivências escolares. Não foram os conteúdos ensinados por nossos "mestres", mas sim sua "personalidade", sua posição diante daquilo que eles ensinavam.

"O aluno se identifica com a posição do professor, mas passará a trabalhar com esse objeto de conhecimento de uma maneira singular porque o tomará a partir de sua singular posição desejante" (KUPFER, 2009, p. 26).

Porém, quando falamos de interlocução, da psicanálise em extensão, da formação do psicanalista e do ensino e transmissão da psicanálise, e trazemos o conceito da transferência também para esse lugar, estamos falando de um outro trabalho, não do trabalho analítico. Na "Proposição de 9 de outubro de 1967", Lacan afirma "que a raiz da experiência do campo da psicanálise colocada em sua extensão [...] deve ser encontrada na própria experiência psicanalítica, tomada em intensão" (p. 8). E o que possibilita essa dobradiça entre intensão e extensão é a transferência, porém não a transferência analítica, mas uma transferência de trabalho.

"Tanto a psicanálise, no amplo sentido que a considera como campo,
como a psicanálise de cada sujeito tomada isoladamente, têm sua base em
nenhum outro lugar senão na transferência. É mesmo somente através da
transferência, desta vez de trabalho, que a psicanálise pode ser
transmitida" (GOUVÊA, 2006, p. 97).

É isso que salienta Lacan (1964) ao dizer na Ata de Fundação da Escola Freudiana de Paris que "o ensino da psicanálise só pode ser transmitido de um sujeito a outro através de uma transferência de trabalho" (p. 23). Assim, na extensão o analista está como sujeito, como sujeito dividido e vai transmitir a partir desse lugar.

Se a interlocução com outros campos de saber trata-se da extensão da psicanálise, neste lugar a transferência que deve operar é também a de trabalho. Uma interlocução, seja ela da psicanálise com a educação ou com qualquer outro campo de saber, só existe se esta "estiver articulada por uma transferência de trabalho em torno do escrito. A transferência de trabalho é à psicanálise e não ao psicanalista” (VIDAL, 2001, p. 52). A transferência de 
trabalho não tem como endereço um sujeito, o analista, ou qualquer outro que fale em seu nome, mas, sim, a própria psicanálise, o discurso que a sustenta. E para que uma transferência de trabalho se instaure é preciso que haja uma torção, implicando uma queda, um abalo na suposição de saber no outro, dando lugar ao texto psicanalítico, onde seus significantes possam trazer como efeito uma novidade e um trabalho próprio.

Eduardo Vidal, num texto não publicado que tem como título "O caso clínico", chama a atenção dos analistas para a escrita de um caso clínico. Ele parte dos cinco grandes casos clínicos escritos por Freud. O que podemos recolher desse texto que nos serve aqui também de direção é o fato de que na escrita de um caso clínico quem fala é o analista. Diferente da direção da cura, ali a pessoa do paciente está apagada, e o que pode ser transmitido são os cortes éticos operados na cura, os momentos de passagem, a estrutura, os significantes, o gozo. Nessa escrita, só há um sujeito, o analista, dando provas da sua prática, da sua ética e do seu desejo. Ou seja, mais uma vez temos a indicação de que no ensino e na transmissão o analista paga também com sua palavra, o analista precisa comparecer como sujeito, do inconsciente. Dessa forma, não é o amor que está no comando. É preciso deixar cair o amor, manejá-lo, pois não estamos livres dos efeitos de grupo, de cola, de monte, de massa. É preciso estar atento ao manejo dessa outra modalidade de transferência, a transferência de trabalho.

Porém Freud, ainda em 1912, escrevendo "A dinâmica da transferência", em suas primeiras elaborações sobre esse fenômeno fundamental da prática psicanalítica, discorre ainda sobre a presença desse fenômeno nas instituições. Na tradução da obra que utilizamos como referência nesse ensaio, lê-se como sanatórios, tais instituições também indicadas para os tratamentos das afecções nervosas. Freud está aqui discorrendo sobre a face de resistência da transferência amorosa, da ambivalência, desse "amódio" que nos diz Lacan, que emperra e paralisa o trabalho analítico. Ele sustenta que muitas vezes, nessas instituições, essa transferência amorosa não traz grandes inconvenientes, pois, ao invés de ser revelada, trabalhada, manejada, ela permanece silenciosa, dissimulada, encoberta, como muitas vezes acontece na vida social. $\mathrm{O}$ amor nas instituições muitas vezes não traz grandes inconvenientes para o próprio sujeito. Em função desse amor, o sujeito se mantém instalado numa mesma posição, muitas vezes de subserviência, de fascínio, de tolerância. Mantém-se trabalhando, às vezes até exaustivamente, produzindo e atendendo aquilo que lhe é 
demandado; porém sem colocar ali algo de seu, sem ter como efeito desse trabalho um produto próprio, com sua marca, mas carregando a marca do Outro.

Todavia, mesmo silenciosa, ela, essa transferência amorosa, não é sem consequências para o tratamento, para o trabalho. Pode não fazer o sujeito abandoná-lo, mas não deixa de ser uma grande resistência, mantendo o paciente instalado no tratamento, ou em seu lugar na instituição e afastando-o da vida real. Podemos transpor tal colocação de Freud quanto ao tratamento nas instituições psiquiátricas para as instituições de maneira geral. Instituições onde não há a escuta do fenômeno da transferência, onde os efeitos de grupo prevalecem, onde o amor e o ódio são tomados na sua dimensão imaginária e a transferência não é lida na sua estrutura significante, onde repousa a estrutura hierárquica que traz como efeito a identificação ao líder. As instituições educacionais não estão fora dessa lógica, desse modelo, como foi apontado anteriormente.

A partir do que Lacan nos ensina e postula quanto à formação do analista e à transmissão da psicanálise, não podemos deixar de apontar aqui essa torção que permite a instauração de uma transferência de trabalho. O que sustenta um ensino e uma transmissão a partir de uma transferência de trabalho é muito menos o saber referencial veiculado aí e muito mais a maneira como o sujeito é causado por aquilo que lhe é transmitido. Ou seja, o que está em causa é o desejo. Para que a transferência de trabalho se instale e possa operar, produzir efeito de transmissão, é preciso uma secagem dessa demanda de saber. É preciso uma torção desse amor de transferência, desse amor ao saber dirigido ao Outro. É preciso que essa demanda não se instale nesse Outro, permitindo uma queda e a possibilidade de uma construção própria do sujeito. É preciso que o professor/educador ensine, transmita, a partir daquilo que ele é causado e não a partir do que ele sabe, assim como é preciso que o professor/educador não se instale no lugar de mestre, detentor do saber, que possa, de certa maneira, a partir desse manejo, transformar uma demanda de ensino em transferência de trabalho, permitindo ao aluno a produção de um saber próprio. Que o professor possa, a partir da escuta e do manejo da transferência e da demanda que lhe é dirigida, fazer uma provocação ao trabalho, uma provocação à construção. Mais uma pergunta nos salta aqui. Como fazer isso? Como um professor/educador poderá sustentar essa posição na sua função de educar? Mais uma vez, a resposta possível é somente a partir de uma aposta. Aposta no 
atravessamento do discurso psicanalítico e que este possa trazer como efeito essa torção na posição do educador diante do fenômeno da transferência.

O professor, ao ensinar, põe-se a falar. Porém não é uma fala qualquer. O professor fala de um lugar específico. Fala a partir dessa disparidade subjetiva e da suposição de saber que lhe é dirigida. O professor, assim como o analista no ensino e transmissão da psicanálise, na psicanálise em extensão, não fala livremente. Lacan dizia ocupar o lugar de ensinante frente a seus pacientes na transmissão. Ensinante no sentido de pagar com a palavra, de falar a partir desse não saber que a experiência analítica põe em campo. Colocar-se na posição de ensinante se refere ao que Eduardo Vidal aponta sobre a posição do analista na escrita de um caso clínico, como já falamos anteriormente, pois é ele, e somente ele, quem fala. Colocar-se como sujeito suposto saber não significa estar de posse desse saber, não é colocar-se como mestre e apoderar-se desse saber.

"Colocar-se no ensino na posição de analista difere do mestre que não sai da posição de saber. Ao analista é possível não saber, gaguejar, balbuciar e não responder à demanda. Nisto há um certo cálculo de como situar-se no discurso" (VIDAL, 2001, p. 52).

Enfim, o professor, assim como o analista, também paga, paga com sua palavra, paga com sua pessoa, por estar nessa posição marcada pelo não saber, pelo saber que se articula em discurso e pode ser transmitido. Se o professor transmite a sua posição, transmite unicamente aquilo que causa o seu desejo. "O professor, então, transmite ao seu aluno aquilo que lhe interessa, ou seja, o modo como conseguiu haver-se com sua angústia" (KUPFER, 2009, p. 26). O professor transmite o modo como conseguiu haver-se com a falta, com a castração, já que é disso que se trata afinal na transmissão. E para que haja ensino, para que haja transmissão, é preciso que haja transferência.

É o aluno quem transfere, sempre, em todo o processo de ensino. Ao professor cabe a contratransferência, assim como estar atento a ela. Ao professor cabe o manejo necessário, cabe encarar as coisas de um ponto de vista diferente, como nos alerta Freud. Ao professor cabe não ignorar seu lugar na economia psíquica do sujeito que lhe dirige sua demanda de saber. O conteúdo, o conhecimento, o saber referencial que ele trabalha com esse aluno, virá sim, por acréscimo. Aqui também é preciso que haja uma torção, que esse amor, que a transferência amorosa possa cair e dar lugar ao trabalho, à transferência de trabalho. Talvez seja esse o segundo tempo dessa transferência. Uma queda que permita ao 
aluno, ao sujeito que inicialmente traz uma demanda de saber ao Outro, formular uma questão, uma questão sobre seu desejo de saber, e apropriar-se dele a partir de uma construção própria. Nesse tempo em que o aluno toma a palavra, fala, escreve, elabora, a transferência que está em causa é a transferência de trabalho. É possível que haja aí uma secagem da demanda para que o desejo do sujeito possa aparecer.

Sendo assim, a psicanálise, na escuta da educação, nessa interlocução, traça dois caminhos que se entrecruzam: a escuta que a psicanálise pode fazer da educação, a partir da escuta dos educadores, nessa interlocução sustentada pelo texto psicanalítico, por uma transferência de trabalho, e a escuta que cada educador pode fazer do seu trabalho, da sua posição, da sua prática, a partir do seu lugar na transferência, à luz da psicanálise, atravessado pelo discurso psicanalítico. E a partir daí, de dar lugar à transferência na sua prática, que o educador possa acolher a demanda, sustentar uma pergunta e permitir assim que um saber seja construído. 
A criança e o saber: sustentando a dimensão do enigma 


\section{Ciranda da bailarina}

(Edu Lobo e Chico Buarque)

Procurando bem

Todo mundo tem pereba

Marca de bexiga ou vacina

E tem piriri, tem lombriga,

Tem ameba

Só a bailarina que não tem

E não tem coceira

Berruga nem frieira

Nem falta de maneira ela não tem

Futucando bem

Todo mundo tem piolho

Ou tem cheiro de creolina

Todo mundo tem

Um irmão meio zarolho

Só a bailarina que não tem

Nem unha encardida

Nem dente com comida

Nem casca de ferida ela não tem

Não livra ninguém

Todo mundo tem remela

Quando acorda às seis da matina

Teve escarlatina

Ou tem febre amarela

Só a bailarina que não tem
Medo de subir, gente

Medo de cair, gente

Medo de vertigem

Quem não tem

Confessando bem

Todo mundo faz pecado

Logo assim que a missa termina

Todo mundo tem

Um primeiro namorado

Só a bailarina que não tem

Sujo atrás da orelha

Bigode de groselha

Calcinha um pouco velha

Ela não tem

O padre também

Pode até ficar vermelho

Se o vento levanta a batina

Reparando bem,

Todo mundo tem pentelho

Só a bailarina que não tem

Sala sem mobília

Goteira na vasilha

Problema na família

Quem não tem

Procurando bem

Todo mundo tem... 
Oito Anos

(Paula Toller e Dunga)

Por que você é Flamengo

Por que o fogo queima

E meu pai Botafogo

Por que a lua é branca

$\mathrm{O}$ que significa

Por que a terra roda

"Impávido Colosso"?

Por que deitar agora

Por que os ossos doem

Por que as cobras matam

Enquanto a gente dorme

Por que o vidro embaça

Por que os dentes caem

Por que você se pinta

Por onde os filhos saem

Por que o tempo passa

Por que os dedos murcham

Por que a gente espirra

Quando estou no banho

Por que as unhas crescem

Por que as ruas enchem

Por que o sangue corre

Quando está chovendo

Por que que a gente morre

Quanto é mil trilhões

Do que é feita a nuvem

Vezes infinito

Do que é feita a neve

Quem é Jesus Cristo

Como é que se escreve

Onde estão meus primos

Réveillon

Well, well, well,

Well, well, well,

Gabriel...

Gabriel 
"Todas as nossas instituições são constituídas para pessoas com um Eu unitário, normal, a que se pode classificar de bom ou mau e que preenche sua função ou dela é excluído por uma influência mais poderosa" (FREUD, 1926, p. 186).

Essa fala de Freud, no texto "Psicanálise e Medicina - Análise Profana", introduz algo que choca seu interlocutor imparcial, ao informá-lo que é muito difícil um neurótico desapegar do seu sintoma e, principalmente, que as instituições nada querem saber daquilo que não anda, que não se enquadra. É com esse rechaço, com esse grande embaraço, que nos deparamos ao acolhermos, na clínica psicanalítica, a demanda de pais e professores quanto aos sintomas infantis.

A escola ${ }^{11}$, lugar privilegiado para o ensino, sendo a instituição educacional por excelência, não se furta a se colocar nessa posição, onde se privilegia esse Eu unitário, não dividido, normal, padronizado. Seguindo a lógica do discurso que atravessa a contemporaneidade, o discurso do capital, do sucesso, da excelência, da eficácia, do consumo, da felicidade, ou seja, de tantos substantivos que apontam para um grande e fascinante ideal, a escola, ancorada pelas diversas políticas educacionais, coloca-se a serviço da avaliação. Dessa forma, privilegia o rendimento, o aprendizado de conhecimentos acumulados e a resposta correta, colocando para debaixo do tapete o fracasso que lhe foge ao controle, que lhe escapa. Ou seja, recusando-se a se deparar com o mal-estar que se apresenta neste lugar.

Mas o que fazer com isso que escapa, com o fracasso, com o marginal? Essa é a pergunta que vem da escola, pelo discurso dos educadores. Tantas técnicas e métodos, tantos manuais, tantos diagnósticos, tantas buscas pela internet, tudo trazendo um conhecimento inabalável sobre isso que não anda bem, que fracassa. Um conhecimento teórico que, por hora, traz certo alívio da angústia, que se mascara de verdade. Tal pergunta não nos chega dessa forma tão elaborada. Aparece como um não-saber o que fazer com isso que foge ao controle. "O que fazer?" vem como uma demanda, na busca de uma resposta ancorada na garantia de que neste Outro há um saber sobre isso que fracassa.

Esse saber inabalável, bem sabido, logo mostra suas rachaduras, seus abalos e, dessa forma, a busca pela verdade, pela resposta, prossegue, persevera. A verdade perseguida insistentemente é a de um saber sem furo, de uma aprendizagem sem tropeços, de um ensino sem embaraços. Uma tentativa infrutífera de educar sem um resto que escapa, denegando o ponto de falta ineducável. Muito se fala de diversidade, de subjetividade no campo da

\footnotetext{
${ }^{11}$ A escola de que se trata neste texto diz respeito à instituição formal de ensino, onde se veicula a educação formal. Não se trata aqui da Escola de Psicanálise.
} 
educação. Porém deixa-se de lado nessas tantas técnicas e métodos, nesses tantos referenciais teórico-práticos, o ponto da diferença, esse ponto que traz no seu cerne a falta.

Mas de que verdade se trata? Essa verdade absoluta da educação plena esbarra na impossibilidade de se atingir a plenitude. Sendo assim, o que a psicanálise teria a dizer à educação? Que especificidade há no saber do psicanalista que possibilita um laço com a educação? O saber que interessa à psicanálise poderia também interessar ao campo educacional? Essas são perguntas que insistem e que viemos perseguindo desde a introdução desse ensaio. A educação vive na impotência da verdade perseguida de uma completude e totalidade. A relação da educação com o impossível está excluída nesse campo. Ou seja, ao perseguir incessantemente esse ideal pedagógico de satisfação, de aprendizagem plena, sem levar em conta esse ponto de falta, sem levar em conta a impossibilidade que perpassa esse campo, a educação permanece na impotência, parecendo desconhecer a impossibilidade que a perpassa.

"Para o educador, ao ter seu trabalho tensionado a partir de um ideal pedagógico, é frequente que o tome no lugar da impotência, ora sua, ora do Estado, ora dos pais dos alunos, etc, mas sempre apontando uma impotência" (VOLTOLINI, 2002).

Tomando tais perguntas como norteadoras desse percurso, é possível fazer um recorte trazendo o ponto da sustentação do enigma a partir do qual é possível apurar a interlocução da psicanálise com o campo da educação; um ponto que faz um corte, que possibilita uma intervenção, um ato; ponto da sustentação do enigma, que, atravessado pelo discurso analítico, permite a construção do saber.

Freud nos coloca, ao introduzir a psicanálise, a seguinte questão: "il y a savoir et savoir, há diferentes espécies de saber que nem todas têm o mesmo valor psicológico" (FREUD, 1917, p. 50). E esse saber do qual se ocupa a psicanálise, o saber inconsciente, não se adquire por acúmulo, recebendo-o pronto por uma comunicação do analista, ou por um vasto estudo teórico. "O saber do médico não é o mesmo do doente e não pode manifestar os mesmos efeitos" (idem). Comunicar ao paciente o sentido de seu sintoma não o fará saber mais do que antes sabia. O saber que interessa à psicanálise é o saber que se subtrai à consciência, saber que deve ser extraído do trabalho psíquico. Se é a partir da relação desses dois campos, Psicanálise e Educação, com o saber, ponto que os aproxima e permite uma interlocução, mais uma vez, fazemos aqui uma aposta na afirmação de que esse saber que interessa e sustenta o trabalho analítico também possa ser de interesse para o campo educacional, a partir da subversão que comporta. 
Esse saber é extraído da experiência, do trabalho de "muitas toneladas de mineral que contém apenas alguns gramas da preciosa matéria procurada" (FREUD, 1926, p. 183). Quanto ao inconsciente, não cabe nenhum convencimento, mas a convicção à qual se chega pelo preço que se paga na experiência. São "palavras, palavras, palavras". E "não devemos desdenhar a palavra" (FREUD, 1926, p. 148), pois são as palavras que põem em campo a dimensão do inconsciente. É nesses fragmentos, nesse pouco, nesses vestígios que aparecem embaçados através das recordações, dos acontecimentos, dos sonhos e dos atos falhos, que o saber se mostra, não-todo, insabido, inconsciente. É com esse lampejo de novidade que vai trabalhar o analista, com essa novidade fugaz, sem descobrir a pólvora ou reinventar a roda, mas na escuta de um significante novo, que salta no discurso e promove uma mudança, produz efeito de deslocamento, desaloja o sujeito e promove um modo inédito de operar com esse saber não-todo. Pois "saber algo não é sempre algo que se produz com um clarão?" (LACAN, 1968-69, p. 196).

Assim apresenta-se o saber inconsciente, como fogo fátuo, como um clarão. É este o ponto que mais nos interessa nessa interlocução, ou seja tal relação com o saber, para que assim possamos abordar a questão da aprendizagem, conceito tão caro para o campo da educação.

A pedagogia, assim como a psicologia, ao privilegiar o saber, formalizando diversas maneiras de abordá-lo, dá a ele um caráter cumulativo, aquisitivo, adaptativo. O saber privilegiado por esses campos é o saber sabido, consciente, saber referencial, conteudista, que se confunde com o conhecimento livresco e pode ser ensinado na escola. São saberes, no plural, como aquilo que se pode aprender, adquirir e acumular numa lógica do quanto mais, melhor. Trabalha uma vertente lógica de que a partir de um bom ensino, com variáveis controladas e resguardadas, é possível chegar numa aprendizagem adequada, satisfatória. Neste sentido, aquilo que falta ou que fracassa, pode ser sempre recuperado a partir de uma correção, de uma outra resposta ou proposta. Porém, como salienta Filho (2001) "todo método de ensinar encerra, além da sua validade, a sua insuficiência” (p. 98). Há aqui, nesta lógica, o privilégio, a primazia e a busca incessante pela resposta, do resultado.

Porém a invenção freudiana traz a novidade de que há um saber que não se sabe; um saber, no singular, simplesmente saber. Assim, subverte o lugar dado a esse saber e aponta que este é falta e, ao faltar, é construído e inventado por cada um a partir do enigma.

Se o saber é isso, algo que se produz, que se conquista, ele é então efeito. É efeito de um trabalho que tem como ponto de partida uma pergunta sustentada numa incógnita. É efeito de um trabalho que se dá na particularidade de cada um e que tem como suporte a 
experiência. E se esse saber se produz como um clarão, ele é um lampejo, é evanescente, não é apreensível, não se pode apoderar dele de forma cumulativa. Ele se dá, e, a partir do corte feito por sua produção, há um efeito de deslocamento na posição daquele que o experimenta. A partir dessa experiência de saber, há a possibilidade de subjetivação, de uma mudança subjetiva.

Sendo assim, o que faz a criança "aprender”? O que desperta seu "desejo de saber"? Neste ensaio privilegiaremos a questão do infantil, da educação infantil, como foi apontado também na introdução. Certamente, quando falamos da experiência analítica e da apreensão desse saber inconsciente, não estamos nos limitando ao trabalho na clínica com crianças. Mas estamos, sim, falando do infantil, da estrutura. Fiquemos por hora com a fala de Lacan de que “o infantil é a estrutura”, para nortearmos o que discutiremos daqui para frente.

Freud, ainda em "Psicanálise e Medicina - Análise Profana", é firme ao debater com seu interlocutor imparcial quanto à questão da sexualidade, principalmente quanto à sexualidade infantil. Este ponto é alvo de grande oposição e desperta ferozes críticas à psicanálise. Ao afirmar a etiologia sexual da neurose e sua constituição infantil, sua presença no sujeito desde o nascimento e a inexistência de pureza e inocência na infância, marcando a diferença entre a vida sexual infantil e adulta, Freud ensina ao leigo interlocutor, e a nós, o ponto radical da sexualidade na realidade do inconsciente e na economia psíquica do sujeito. O que Freud nos ensina é que a sexualidade está para além do sexo e da genitalidade. O que está em questão é a diferença, a relação de um sexo e o outro, como nos aponta Lacan. O que interessa é a incidência do sexual naquilo que ele remete à divisão, ao seccionar o sujeito, como marca da castração simbólica. Este é o ponto radical da sexualidade na realidade do inconsciente, ou seja, o ponto da divisão, o que faz do sujeito, dividido.

"Nossa civilização se forma à custa da sexualidade" (FREUD, 1926, p. 171) e para abordá-la é preciso ir além dos conhecimentos anatômicos e fisiológicos. Para tanto, torna-se “indispensável uma certa familiaridade com a História da Civilização e a Mitologia” (p. 172). Diante do enigma, desse ponto onde falta a palavra, cria-se o mito. A história da civilização está referida à tradição, àquilo que se transmite, à "primitiva herança humana" (p.177). A tradição transmite aquilo que se inscreve na cultura e que foi rechaçado na registro escrito da história. Mitologia e tradição dão lugar ao simbólico, ao "caldo cultural" no qual estamos imersos. A pré-história da humanidade e a mitologia, assim como a pré-história do sujeito e sua sexualidade, despertada na mais remota infância, estão perdidas "sob o véu da amnésia", porém não estão apagadas. São os vestígios, as marcas, os pontos de fixação nos quais tropeça a sexualidade, que dão notícias da neurose infantil, assim como do avanço da civilização. 


\begin{abstract}
“A civilização se baseia, em geral, na renúncia às pulsões, e cada indivíduo tem que repetir pessoalmente, no seu caminho da infância à madureza, esta evolução da humanidade até a resignação razoável. A psicanálise mostrou que são, predominantemente, senão exclusivamente, moções pulsionais sexuais as que sucumbem a este recalque cultural (FREUD, 1910, p. 86).
\end{abstract}

Para falarmos de história da civilização, também não podemos nos deter somente em fatos e narrativas históricas, documentadas e registradas pela escrita. A narrativa histórica com a qual a psicanálise trabalha traz a verdade com estrutura de ficção e privilegia a realidade psíquica, e não a realidade material. É nesta linha tênue que separa e enlaça a verdade dos fatos da verdade do sujeito, a realidade factual da realidade psíquica, que se constrói o relato histórico transmissível e que cada sujeito, cada neurótico construíra seu mito individual. E a passagem pelo complexo de Édipo é a construção do mito individual de cada neurótico. É a partir da sua novela, do seu romance familiar no qual cada sujeito se coloca como protagonista, juntamente com seus coadjuvantes nesta cena fantasmática, que ele poderá construir sua história.

Freud lançou mão do mito de Édipo, cujo destino é paradigma para todos os homens, como nos transmite poeticamente Sófocles para falar dessa operação fundamental da estruturação e constituição do sujeito. Se o infantil é a estrutura, a neurose é infantil. E o complexo de Édipo é o seu operador, é "o complexo nuclear da neurose". E se o complexo de Édipo é, como nos aponta Millot (2001), "a pedra de toque de todo empreendimento educativo" (p. 78), não podemos aqui deixar de abordá-lo com rigor.

Dois motivos nos fazem aqui abordar o mito edípico: primeiro, por sua importância teórica, por seu fundamento, por ser estrutural e sua função operadora na constituição do sujeito, ou seja, por ser paradigma para todos os homens; segundo, porque esse conceito psicanalítico, fundamental, saiu do círculo restrito da psicanálise e, há muito, caiu no senso comum da cultura e hoje muitos falam do complexo de Édipo de uma forma quase que banal, principalmente no campo educacional, no qual as questões do infantil são tão presentes. A pedagogia e a psicologia se apropriaram desse conceito, fundamental e tão caro à psicanálise, e fizeram dele outra coisa. Todos aqueles que trabalham na educação infantil certamente já ouviram ou já falaram do complexo de Édipo, sem mesmo se dar conta de que estão falando, mesmo com equívocos, de psicanálise. A demanda que muitas vezes chega na clínica psicanalítica vinda da escola traz diagnósticos que se referem de forma equivocada ao complexo de Édipo. Escutamos coisas tais como: “meu filho está com complexo de Édipo, foi isso que a professora disse!", “fulaninho só quer dormir comigo, tá sofrendo de complexo de Édipo"; tantas outras falas similares, que portam o equívoco e a crença de que o "complexo de 
Édipo" é uma nova síndrome, um novo sintoma, dentre tantos sintomas que a contemporaneidade "inventou".

Freud construiu a teoria do complexo de Édipo a partir de sua prática clínica, da escuta da neurose infantil de seus pacientes e baseando-se no mito de Édipo Rei, na tragédia grega narrada por Sófocles. A descoberta do complexo de Édipo é concomitante com a descoberta do inconsciente, outro conceito fundamental e puramente psicanalítico, que também caiu nas graças do senso comum.

O mito edípico não é a simplória historinha do filho que rivaliza, odeia e mata o pai, e deseja e desposa a mãe, como tão comumente ouvimos no senso comum. A trama dessa novela familiar é muito mais engenhosa e por isso Freud dá o nome de complexo. Não porque traga uma complexidade ou que seja algo patológico, uma síndrome como a psiquiatria ou a psicologia classificariam, algo que deva ser eliminado, mas, sim, porque há uma trama, uma rede que vai se formando, constituindo-se, a partir da relação do sujeito com seu objeto de amor. E esse emaranhado, essa tessitura tem função determinante na constituição do sujeito.

$\mathrm{Na}$ história do mito, temos elementos de fundamental importância para a teoria do complexo de Édipo. Não só o incesto e o parricídio, mas, também, e principalmente, a universalidade paradigmática dessa relação, o não-saber, a predição disso que já está dado e que não há como escapar, além da tragédia em si, própria do romance familiar de cada sujeito.

O complexo de Édipo, além de ser o complexo nuclear das neuroses, é também o momento decisivo em que culmina a sexualidade infantil, em que se dá a estruturação do sujeito, de sua sexualidade. Neste tempo, definem-se as marcas que serão resignificadas na vida adulta. Falar de complexo de Édipo é falar da sexualidade infantil e os desejos edipianos vão aparecer, num primeiro momento, como conteúdo das fantasias sexuais que giram em torno dos pais, a partir dos romances familiares. Em torno dos 3 e 5 anos, vivenciando um período fálico, no qual está em questão para o sujeito infantil o seu “faz-pipi”, tem-se início o conflito edípico. Neste momento, há a primazia de um único órgão sexual, o masculino, e todo o interesse da criança gira em torno desse tema. Para o sujeito infantil, tanto menino quanto menina, pois nesse momento ainda não se tem a distinção anatômica entre os sexos, os seres são classificados em fálicos, possuidores de pênis, e não fálicos, castrados, não possuidores de pênis. O órgão sexual feminino ainda é desconhecido e não há a distinção entre masculino e feminino. É nessa fase que a criança começa a fazer suas descobertas quanto à diferença anatômica, ao se deparar com os genitais de um amiguinho de brinquedo ou mesmo de um irmãozinho. Tem-se início a masturbação dos genitais, provocando um excesso de prazer e satisfação, e a construção das teorias sexuais infantis, importantíssimas no 
que se refere à construção de um saber. O fato de existirem dois sexos é inicialmente aceito pela criança com naturalidade, sem maiores problemas e questões. Ela sabe da diferença, porém não a associa à diferença sexual. A ideia de que todos, homens e mulheres, possuem um pênis persiste. É somente num segundo tempo, a partir da construção das teorias sexuais e de sofrer a ameaça de castração, a ameaça de perder seu tão precioso "faz-pipi", que a criança se vê tomada de angústia diante disso.

O senso comum, a pedagogia, a psicologia também se apropriaram dessas construções teóricas da psicanálise de forma quase banal, cristalizando a questão da sexualidade infantil na passagem pelas fases do desenvolvimento psicossexual. Freud, em 1905, escreve os "Três ensaios sobre a teoria da sexualidade" ${ }^{\prime 2}$. Detêm-se, no segundo ensaio, na sexualidade infantil e discorre sobre as fases oral, anal, genital, denominadas fases do desenvolvimento psicossexual. Neste momento de seu percurso teórico, ainda em construção, Freud fala de desenvolvimento, porém uma leitura atenta e rigorosa deixa bastante claro que não se trata de uma passagem cronológica, estanque ou desenvolvimentista. Não se cumpre uma fase para que se possa passar para outra. A passagem por elas deixa restos, vestígios, pontos de fixação que podem ser lidos nos sintomas neuróticos ou mesmo em práticas e hábitos adultos. Freud está aqui trabalhando, ainda sem muitos recursos, a estruturação do sujeito, aquilo que é constitucional. A partir de suas elaborações quanto ao complexo de Édipo uma torção é feita e o estádio genital é substituído pela noção de estádio fálico. Porém, é somente a partir dos anos 20, ao elaborar sobre o complexo de castração e articulá-lo ao complexo de Édipo, que Freud avança sobre as questões do período pré-edípico e o que ele comporta de edípico. Até então, na obra freudiana, o acento recaía no vínculo paterno que está em questão no complexo de Édipo. A partir daí, um passo é dado na obra freudiana tendo início suas elaborações sobre a organização genital infantil e a distinção anatômica entre os sexos, as investigações sobre a sexualidade feminina e a feminilidade. Freud tece considerações sobre o reconhecimento de um vínculo primitivo com a mãe, a partir da pré-história do complexo de Édipo, ponto que passa a ser central para se aceder à feminilidade, ponto ao qual Freud passa a dar mais importância do que a "inveja do pênis", considerado como central até então.

Hoje está na ordem do dia falar de sexualidade, de orientação sexual ou mesmo de educação sexual. A escola se volta para tais questões, porém nesse sentido, da orientação, da explicação, do ensinamento sobre o sexual; ou seja, no sentido de dar respostas à uma demanda de saber dirigida aos outros campos de saber, uma resposta aos embaraços que se

\footnotetext{
${ }^{12} \mathrm{O}$ texto leva o título de "Uma teoria sexual" na tradução da Delta, que estamos utilizando como base nesse ensaio.
} 
manifestam na escola diante desse ponto da sexualidade. Se não estivermos atentos, caímos mesmo no engano da orientação, e deixamos passar a construção, a descoberta da criança, ou seja, o que realmente tem importância nesse momento. A sexualidade é um ponto de embaraço para todo e qualquer sujeito. E, sendo assim, há uma grande dificuldade em lidar com a sexualidade infantil, há um grande embaraço por parte dos adultos em lidar com a criança que traz questões que apontam para a sexualidade.

Para a psicanálise, o que está de fato em questão é a sexualidade, o sexual e não o sexo, o ato sexual genital. É sexual aquilo que traz para o sujeito uma satisfação. As manifestações sexuais infantis estão sempre associadas a uma das funções somáticas vitais. Tais manifestações não conhecem um objeto sexual, ou seja, são auto-eróticas e seu alvo sexual encontra-se sob o domínio de uma zona erógena. Essas zonas erógenas, essa parte da pele ou das mucosas, ao serem estimuladas, provocam sensações de prazer, de satisfação. Essa manifestação da sexualidade infantil faz com que a criança tenha uma disposição sexual perversa polimorfa, ou seja, como ela ainda não tem constituído os diques, as barreiras, contra os excessos sexuais, diques tais como a vergonha, a moral, o nojo, ou estes ainda estão em processo de construção, manifestam esses atos ainda sem muita resistência, com bastante espontaneidade.

Por isso a grande importância de abordarmos o complexo de Édipo, pois é a partir da incidência deste, da ameaça de castração, da passagem pela fase fálica, que esses diques, essas barreiras, constituem-se, servindo de muro a essa excitação, fazendo uma barra e permitindo que essa energia seja direcionada para outros fins. Embora a mãe, primeiro objeto de amor da criança torne-se aqui também o alvo sexual desta, as manifestações sexuais ainda são autoeróticas, e se tem início as manifestações sexuais masturbatórias, ou seja, a manipulação do órgão genital. Mas é somente na puberdade que surge o primado da genitália, momento em que a sexualidade é posta a serviço da reprodução, com da renúncia dos objetos de amor infantis e o endereçamento a outro objeto sexual.

Neste primeiro tempo, antecedente à passagem pelo complexo de Édipo, tanto o menino quanto a menina tem a mãe como seu primeiro objeto de amor. Esse vínculo primitivo com a mãe diz de um ponto mítico, muito precoce, difícil inclusive de ser determinado com precisão. Até esse momento, a menina se comporta como um pequeno homenzinho e por isso falamos aqui em sujeito infantil, pois não se trata de gênero. Há nesse momento uma simetria no desenvolvimento psicossexual dos dois sexos. É a partir da descoberta da diferença anatômica entre os sexos que a sexualidade seguirá caminhos divergentes para cada sexo. Surge aí o conflito edipiano dando lugar a dois desfechos diferentes. 
A pré-história do complexo de Édipo, a fase pré-edípica, na menina perdura por um tempo excessivamente longo e indeterminado. Já no menino, tal pré-história não é muito clara. A pré-história não é, como muitos pensam, a herança dos antepassados. Essa préhistória é vivida na existência individual de cada sujeito, na sua infância. A pré-história do sujeito é o pré-edípico, é a pré-história do romance tecido no emaranhado dos fios do conflito edípico. E a pré-história é encoberta pelo véu da amnésia infantil, fenômeno psíquico que faz com que só tenhamos lembranças incompreensíveis, vagas e fragmentárias dos primeiros anos da infância.

No menino, a entrada no complexo de Édipo se dá no decorrer da vivência fálica, no auge de sua excitação sexual e do investimento libidinal no seu "faz-pipi"13. A mãe é mantida nesse lugar de objeto de amor e o menino encara o pai como seu rival. Há um grande investimento narcísico nos órgãos genitais, ocasionando a masturbação, que serve como descarga para a excitação própria do complexo de Édipo. A supressão da masturbação por parte daqueles que cuidam da criança coloca em ação o complexo de castração. Tal ameaça comumente vem da figura feminina, da mãe ou da babá, que a atribui muitas vezes à figura masculina, ao pai. É o pai o operador da lei contra o desejo incestuoso do filho, inscrevendo o limite, a barra a esse desejo. É o pai o operador da interdição, e que num só golpe interdita não só o filho, mas também o desejo da mãe.

O menino, ao perceber a diferença anatômica, a ausência de um "faz-pipi” como o seu nas meninas, vislumbra a possibilidade de também perder o seu. Porém, ao se deparar inicialmente com essa diferença, ele a rejeita e ignora. É somente mais tarde que a ameaça de castração sofrida ganha seu efeito adiado. É a partir do terror de perder seu precioso órgão, como uma punição do pai, que o complexo de Édipo, no menino, submerge, sucumbe ao recalque, dando lugar à latência.

$\mathrm{Na}$ menina, o itinerário que se segue é bastante diferente. Da menina é exigido um trabalho a mais para que o complexo de Édipo sucumba ao recalque. Esse trabalho a mais exigido para se aceder à feminilidade se refere à vivência da pré-história, a esse vínculo primitivo com a mãe. Também na menina, a mãe é o primeiro objeto de amor e seu vínculo com esse objeto primitivo se estende por um tempo bastante longo. Na menina, o complexo de Édipo constitui uma formação secundária.

\footnotetext{
${ }^{13} \mathrm{O}$ caso clínico do Pequeno Hans é de grande ajuda para exemplificar esse momento. Inclusive Freud escreve o historial clínico de Hans justamente para comprovar clinicamente, a partir da prática, suas elaborações teóricas expostas nos "Três ensaios sobre a teoria da sexualidade".
} 
Ao se deparar com a diferença anatômica, a menina não tem dúvidas, não hesita. Ela vê, sabe que não tem e quer ter. Ela cai vítima da "inveja do pênis". É a descoberta de sua falta de pênis, desse órgão tão precioso e desejado que faz com que ela se volte para o pai, marcando sua entrada no complexo de Édipo. Abandona a mãe como objeto e a responsabiliza por tê-la colocado no mundo "insuficientemente aparelhada", assim, volta-se para o pai, de quem acredita poder receber algo que lhe compense essa falta. Assim, não há na menina um motivo para a submersão do complexo de Édipo e este vai sendo abandonado lentamente.

"Enquanto, nos meninos, o complexo de Édipo é destruído pelo complexo de castração, nas meninas ele se faz possível e é introduzido através do complexo de castração" (FREUD, 1925, p. 277).

Um dos sintomas infantis mais comuns que surgem diante da angústia de castração são os episódios fóbicos. Inicialmente, esses episódios aparecem sem um objeto determinado apresentando apenas uma avassaladora angústia frente à grande excitação dos órgãos genitais, à masturbação e ao desejo pela mãe. Posteriormente, um objeto fóbico é eleito, normalmente algo que faça parte da vida da criança, algo com que ela tem grande proximidade. Os sintomas fóbicos na infância servem como uma barra, um parapeito, a essa grande excitação e a esse desejo pela mãe, quando esse limite, essa interdição necessária, posta pelo pai, ainda está frouxa, vacilante. Todavia, tais episódios fóbicos podem acontecer em graus mais ou menos intensos e uma fobia só se apresenta como patológica, como um sintoma que necessita ser tratado, quando provoca um impedimento grande ou um sofrimento devastador na criança. Ou mesmo quando persiste para além da submersão do complexo de Édipo, avançando pelo período de latência. Tais sintomas fóbicos podem, muitas vezes, se manifestar na escola. Pois a escola é o espaço de relações sociais da criança e é neste lugar, assim como na família, que tais sintomas irão se manifestar.

Na latência toda essa excitação e desejo ficam latentes, ou seja, não desaparecem, mas ficam fervilhando, submersos, contidos. Houve uma contenção, uma barra foi colocada, agora os diques da vergonha, do pudor, da moral, estão bem instalados, possibilitando à criança se debruçar sobre outros interesses, como a leitura, a escrita, as operações matemáticas.

Voltemos ao enigma. Este sempre se refere às origens e à existência. O enigma proposto pela esfinge tebana a Édipo assim como a pergunta perturbadora da qual se ocupa o sujeito infantil, sintetizada por Freud na fórmula "de onde vêm os bebês?", trazem a questão sobre a origem e a existência, "a interrogação mais remota e ardente da humanidade" (FREUD, 1907, p. 113). Por isso a importância de trilharmos esse percurso pelo complexo de 
Édipo, pois é a partir dessa passagem que o sujeito infantil poderá construir suas teorias sexuais e um saber sobre elas.

A pergunta "de onde vêm os bebês?" se impõe como o primeiro grande enigma que aguça a curiosidade da criança, abrindo a possibilidade para a construção das teorias sexuais infantis. A "pulsão de saber" (wisstrieb) é posta, pela criança, a serviço de suas energias intelectuais.

Esse primeiro grande problema se instaura no instante preciso da entrada de um outro que ameaça a posição confortável da criança diante da mãe. A diferença sexual, que de início é recusada e nem mesmo percebida pela criança, ganha seu efeito adiado quando ela se coloca a investigar e construir esse saber sobre o sexual. Ou seja, a partir de uma contenção dessa excitação sexual e de sua atividade masturbatória, a criança pode direcionar essa pulsão de saber para questões intelectuais, que exigem dela uma capacidade mais elaborada de pensamento e de invenção. O que Freud nos aponta é que para elucidar a questão da origem é preciso uma construção; uma construção no sentido do mítico, da herança, da tradição, que traz a verdade em sua estrutura de ficção, mesclada com enganos, nas lacunas deixadas pela história. Esse é o trabalho de construção de Freud no mito do pai da horda e na história do povo judeu em "Moisés e o Monoteísmo".

A construção das teorias sexuais é parte integrante, fundamental da constituição psíquica do sujeito. Tais teorias são como a construção do mito individual de cada neurótico. Assim como o complexo de Édipo, as teorias sexuais infantis são estruturais. Trazem o ponto do universal e dizem respeito à nossa herança simbólica. São fundamentais na constituição da neurose e dos sintomas, é aquilo que fica como resto da infância.

\footnotetext{
"Interesses práticos e não apenas teóricos são os que desencadeiam na criança a obra da atividade investigadora. [...] Em geral pode-se dizer que as teorias sexuais infantis são imagens da própria constituição sexual da criança e que, apesar dos grotescos erros, indicam maior compreensão dos processos sexuais do que se suspeitaria em seus criadores" (FREUD, 1905, p. 73/75).
}

A primeira teoria construída pela criança retoma o ponto que ora fora rechaçado ou sequer colocado em questão: a diferença sexual. Em consonância com o período fálico, pelo qual a criança está transitando, há somente um órgão sexual, o masculino. É a primazia fálica, na qual a criança atribui a todos a posse de um pênis. $\mathrm{O}$ caso do Pequeno Hans nos serve aqui de exemplo, a partir do qual, de início, humanos e não humanos, animados e inanimados, homens e mulheres possuem o tão precioso "faz-pipi". A chegada da irmãzinha instaura a curiosidade perturbadora e a incessante pesquisa sobre a diferença sexual. 
Uma segunda teoria traz para o campo da investigação a crença de que o bebê é expelido como excremento. Esta construção se apóia na primeira, na ignorância do órgão genital feminino. A pesquisa fracassa e prossegue, dando margem à terceira das teorias, na qual o coito tem sempre um caráter sádico.

Outras teorias ainda são elaboradas, na busca e na construção da criança por esse saber sobre o sexual, pela resposta desejada, pelo desejo de saber. Com o passar do tempo, tais teorias tornam-se mais sofisticadas, porém continuam a esbarrar num ponto de falta, de ignorância, no impossível de saber que essa busca comporta.

A criança, ao tropeçar nesse ponto de falta, ao fracassar em suas investigações, ao se deparar com a verdade pela metade e com o engano que comporta suas teorias, é impelida a abandonar suas pesquisas. "Tais falsidades e dúvidas se constituem em protótipo de todo processo mental posterior encaminhado para a solução do problema e o primeiro fracasso exerce já, para sempre, uma influência paralisante" (FREUD, 1908, p. 129). Assim como os mitos, as teorias sexuais são meias-verdades, e entre enganos, tropeços, fracassos e descobertas, a criança vai construindo, não sem perda, um saber e vai bordeando o buraco desse impossível.

\footnotetext{
"O conhecimento das teorias sexuais infantis, tal e como o pensamento infantil as compreende, pode ser interessante em mais de um sentido, e assim resulta sê-lo também, surpreendentemente, para a interpretação dos mitos e fábulas da antiguidade. Mas torna-se indispensável para a concepção das próprias neuroses, nas quais as teorias infantis conservam ainda todo seu valor e exercem uma influência determinante sobre a estrutura dos sintomas" (FREUD, 1908, p. 122).
}

É somente ao se deparar com o real da castração, com a ausência do pênis da mãe, num "só depois", que a criança abandona radicalmente toda investigação intelectual neste sentido. É nesse tempo, no qual a ameaça de castração ganha seu efeito adiado, que se impõe, para a criança, a exigência de abandonar o prazer da excitação e das manifestações masturbatórias e suas investigações quanto ao sexual. O abandono, a renúncia a tais investigações é concomitante com a submersão do complexo de Édipo. As teorias sexuais infantis também sucumbem ao recalque e delas só temos notícias através do seu retorno como sintoma na neurose. Uma renúncia pulsional, dessa "pulsão de saber" (wisstrieb) é exigida, para que a criança possa aceder a um outro aprendizado, das letras e dos números, sustentado nessa base estrutural submersa pelo recalque, que dá a chave para o desejo, instaurando o período de latência. Sendo assim, "para estruturar corretamente um saber, é preciso renunciar a questão das origens" (LACAN, 1969-70, p. 17). 
O período de latência se caracteriza por esse refreamento da pulsão sexual, por uma renúncia necessária da satisfação pulsional, possibilitando que essa energia seja direcionada para outros fins, permitindo o desenvolvimento cognitivo da criança. Nesse período, não desaparecem as investigações quanto à sexualidade, porém tais investigações permanecem latentes, fervilhantes sob a barra do recalque, prontas para mais tarde ganhar força e se manifestar novamente no período da puberdade. O período de latência é essa "lacuna hiante", esse intervalo generoso que permite ser encoberta, preenchida ou mesmo remendada, através de uma outra investigação que necessita ser construída. É o tempo do esquecimento, tempo que recobre o esquecimento radical da amnésia infantil, do qual só se pode ter notícias de maneira isolada, incompleta e fragmentária, a partir das "lembranças encobridoras".

É nesse tempo da latência, nesse intervalo, nessa aparente calmaria, que se abre uma possibilidade para a construção, para o aprendizado de algo novo. Nesse tempo, a energia gasta antes com as investigações sexuais, é direcionada para o aprendizado, para outras investigações intelectuais e cognitivas.

Podemos aqui lançar mão da arte para ilustrar e nos aproximar do que estamos tentando abordar. O filme francês "Le petit Nicolas" "14 nos mostra de forma poética, divertida e leve a angústia da criança diante da chegada de um irmãozinho, assim como as elaboradas teorias para dar conta desse ponto enigmático. O filme, adaptação do clássico personagem francês criado por René Goscinny e Jean-Jacques Sempé, traz a história de Nicolas, um menininho esperto e amável, que juntamente com seus amigos de escola dão asas à imaginação e à fantasia para criarem uma maneira de eliminar este suposto irmão que está para chegar. Ao assistir o filme temos a impressão de termos vivenciado também as aventuras e traquinagens do pequeno Nicolas. E será que não vivemos? Cada um à sua maneira? E é assim, como o pequeno Nicolas, que as crianças vivem, imersas no brincar e na fantasia, construindo seu mundo, seu romance, sua realidade e sua verdade, para que possa aceder ao seu desejo. As pequenas grandes ocorrências da infância, retratadas no filme com tanta simplicidade e humor, permite a nós, adultos, recordar e, por que não, nos reconciliar com esse ponto do infantil que permanece em nós, adormecido.

O que norteia toda a história do filme é a pergunta lançada pela professora, "o que você quer ser quando crescer?" E sem ter uma resposta para tal pergunta, Nicolas permanece com o enigma, que lhe permite construir e avançar em suas investigações.

\footnotetext{
${ }^{14}$ Le petit Nicolas, filme francês, de 2009, adaptado da obra de René Goscinny e Jean-Jacques Sempé, com direção de Laurent Tirard e estrelado por Maxime Godart no papel de Nicolas.
} 
O filme se passa nos anos 50, numa escola francesa só para meninos. Aparecem ali os pequenos alunos, de forma bastante caricata, cada um com uma característica que os define e os estigmatiza perante da turma. Há o gordinho e comilão, o distraído e burro, o arrogante rico e dono de si, o inteligente e queridinho da professora, entre outros, com qualidades e defeitos bastante acentuados e que, por isso, para Nicolas, torna-se bem claro o que cada um quer ser quando crescer. E há também aquele que queria ganhar uma bicicleta, mas que acabou ganhando um irmãozinho. E a partir daí, da pergunta ao amigo de como isso aconteceu e da resposta que aponta os indícios naquilo que aparece na relação dos pais, Nicolas formula uma nova questão. A questão de onde vêm os bebês. É a partir de tal questão que as fantasias ganham forma e força, e as traquinagens da infância dão o tom e o colorido divertido e leve ao filme.

A questão de onde vêm os bebês traz junto com ela uma série de elucubrações sobre a relação dos pais, sobre o casamento, sobre a diferença anatômica, sobre a ambivalência de afetos, o temor de ser abandonado e substituído. É a ambivalência do complexo edípico fortalecida pelo horror trazido pela ameaça de castração, que neste momento ganha força e tem seu efeito. E, ao final, depois de desfiar o rosário das fantasias e de debulhá-las, a questão quanto à origem desemboca novamente sobre a questão quanto ao desejo. O que você quer ser quando crescer? traz a questão quanto ao desejo e o lugar que se ocupa no desejo do Outro. E só se pode chegar a ela tendo avançado na questão da origem; ou melhor, renunciando à questão da origem a partir da construção de suas teorias, de seu romance familiar e de suas fantasias.

Muito se poderia aqui comentar sobre o filme "Le petit Nicolas", porém aquilo que mais nos interessa é justamente esse ponto da fantasia, da construção a partir de um enigma proposto e da sustentação desse enigma para que algo do desejo possa advir.

É assim que Nicolas chega à conclusão do que quer ser quando crescer. Já com a angústia amenizada quanto à chegada de seu próprio irmãozinho, Nicolas é novamente surpreendido, pois não recebe um irmãozinho, mas sim uma irmãzinha. Ela não jogaria bola com ele, não aprenderia andar de bicicleta, não saberia brincar de batalha... E assim ele descobre, ou se dá conta, a partir da sua própria mensagem recebida de forma invertida do campo do Outro, que ele poderia fazer as pessoas rir.

O pouco que a psicanálise teria a dizer à educação está referido à questão do enigma, a partir do que pudemos articular até então. E mais uma vez trazer para essa interlocução uma aposta de que, também na educação, haveria um lugar para o enigma. 
A educação, assim como a psicanálise, comporta a dimensão do impossível. "Se não é possível ensinar tudo a todos, teremos de concluir que existe na educação algo que só poderá ser pensado na categoria do impossível”, como nos alerta Filho (2001, p. 93). A novidade instaurada pela psicanálise, no campo do saber, não é sem efeitos na educação, como pudemos elaborar no capítulo anterior. O saber é extraído da experiência, é saber que visa a perda e não o acúmulo de conhecimentos, é um saber que se subtrai da verdade, uma verdade que não é absoluta, mas sim não-toda, verdade que se articula com a realidade psíquica do sujeito e que será experimentada na sua radicalidade. Não há verdade absoluta, pois esta é tomada na sua estrutura de ficção, particular para cada sujeito, construída com os restos, os vestígios e nas lacunas de seu romance familiar. O saber, tomado nessa dimensão do impossível, do saber não-todo, é saber que só se adquire, só se apreende na experiência. É saber no singular, saber próprio, é saber que faz corte, que não se acumula. O que está em cheio no saber que nos interessa é a noção de perda, assim como o que está na origem do desejo é essa perda radical que diz do sexual, que secciona, que divide, que instaura a falta, e não saber que completa, que soma, que se acumula, que se adquire através de informações. $\mathrm{O}$ saber que está em questão para nós é de outra ordem, é o saber que toca no enigma, e não esse "saber consciente, que é pertinente ao "eu" e passível de controle e avaliação" (FILHO, 2001, p.74). O enigma é uma enunciação. É o sujeito que vai transformá-lo em enunciado, como Édipo, e fazer dele sua verdade. A enunciação não vem com uma significação pré-fixada, estabelecida, determinada a priori. Essa significação só é dada num depois, a partir de uma construção. E assim podemos tomar o mito edípico como paradigma. Pois é somente a partir de um trabalho, de uma elaboração e da construção desse romance que se pode chegar a uma significação.

É somente pela experiência que também um educador pode apreender o saber da psicanálise. Afirmação da qual Freud não cede, sustentando o ponto radical desse saber. Assim, podemos retomar a indicação freudiana de que a psicanálise pode servir não para a educação em si, mas sim trazer algo inédito para a condição daqueles que estão empenhados no ato de educar. O atravessamento pelo discurso psicanalítico não faz do educador, psicanalista e muito menos lhe dá condições de sustentar um ato analítico. Seria utópico, ideal e mesmo ingênuo acreditarmos que todo educador deveria submeter-se à experiência da análise para que pudesse educar. Esta não é e nunca será uma pré-condição para ser educador. Educar está aí, como prática impossível, instaurando e fazendo avançar a civilização e o que a psicanálise possibilita é não mais que fazer uma leitura dessa prática a partir de seu discurso. O que o educador pode buscar aí, no saber psicanalítico, nesse discurso, ao ser tocado por ele, 
por seus significantes, é uma leitura outra, inédita, sobre o ato que ele produz, ou seja, o ato educativo. Um educador, ao se deparar com os significantes da psicanálise, pode ser fisgado por esses e a partir daí fazer uma demanda de análise e fazer a passagem por essa experiência singular. Porém, mais uma vez, essa não é uma pré-condição, mas, sim, um efeito; efeito de transmissão do ensino da psicanálise a educadores, efeito de transmissão da incidência do saber psicanalítico, do discurso psicanalítico perpassando o campo educacional.

Esta é a aposta que perpassa todo esse ensaio, do seu início ao fim. Não encontraremos aqui respostas ou soluções de como deveria ou poderia se dar a transmissão da psicanálise à educadores ou como seria esse atravessamento da educação pelo discurso psicanalítico. O que se faz aqui, neste ensaio, é somente uma posta numa outra possibilidade de leitura do ato e da função de educar, perpassado pelo discurso e os significantes da psicanálise.

“O inconsciente é o ponto nodal de um saber falho. É daí que nasce o desejo, e sob a forma do que pode assim ser chamado de desejo de saber" (LACAN, 1968-69, p. 265). É a falta que põe em campo o desejo e este é sempre desejo do Outro. A pedagogia, a educação, “desconhece a função da sexualidade no despertar do saber" (VIDAL, 1999, p. 21). Esse desconhecimento é de todos os sujeitos, é um dado de estrutura e é a psicanálise quem vem deflagrar esse saber. A pedagogia, a educação, desconhece também que importa menos a resposta oferecida ou encontrada que a pergunta sustentada. Desconhece a barra sob a qual está o saber, desconhece que este saber é falho e que o enigma vem do campo do Outro. Esse desconhecimento faz com que a educação não perceba a hiância que se faz presente entre conhecimento e saber. Saber e conhecimento estão para o campo educacional como uma única e mesma coisa. Para o campo psicanalítico, conhecimento e saber estão dissociados, havendo uma lacuna, uma hiância, ou mesmo uma disparidade entre esses dois conceitos. O conhecimento, este sim, é veiculado através da informação, do ensino, dos métodos e técnicas de ensino-aprendizagem. Mas o saber, a partir da incidência do discurso psicanalítico, este só advirá como um clarão, como efeito, a partir da sustentação de uma questão que possibilite uma construção.

É isso que nos aponta Filho (2001) ao afirmar que no campo educacional

"o saber deixou de ser percebido como uma conquista para enquadrar-se como uma aquisição, de modo que não exista criação, e sim adequação. Isso resulta em que todos os pais mandem seus filhos à escola para que aprendam o que o professor repete, desde que evidentemente, ele seja licenciado, e que o aluno se limite a perguntar aquilo para o que o professor já detém a resposta. Na modernidade já não há mais espaço para o mestre que ensina com perguntas" (p. 94). 
Porém, na aposta que fazemos e sustentamos aqui, a função do professor/educador na aprendizagem é a de sustentar a dimensão do enigma e privilegiar a pergunta que possa relançar o desejo de saber, e permitir assim uma construção. O professor não é aquele que vai decifrar o enigma, mas, sim, aquele que vai mantê-lo aberto, acesso, que vai sustentá-lo para permitir ao sujeito se virar como puder, convertendo essa enunciação em enunciado, construindo assim um saber próprio. É aí, nesse intervalo, que pode também o professor/educador intervir, sustentando essa hiância, a hiância instaurada pelo enigma, para que haja a possibilidade de se aceder ao saber. O desejo de saber não leva ao saber. O que leva ao saber é o enigma. Assim, como o analista, o professor/educador, atravessado pelo discurso da psicanálise, sustenta a aprendizagem se colocando na posição de suposto saber, como pudemos trabalhar no capítulo anterior. "Aprender é sempre apre(e)nder o significante do Outro, fazer próprias as palavras que formam o tesouro de uma língua" (VIDAL, 1999, p. 27). Aprender é construir, é poder operar com o saber que falta e inventá-lo.

Nas palavras de Lacan:

"O saber é isso: alguém lhes apresenta coisas que são significantes e, da maneira como estas lhes são apresentadas, isso não quer dizer nada, e então vem um momento em que vocês se libertam, e de repente aquilo quer dizer alguma coisa."(1968-69, p. 196).

A aposta que fazemos aqui é de pensar a educação pela via da construção, atravessada pelo discurso psicanalítico. O atravessamento pela psicanálise e o saber decantado da experiência analítica possibilitam ao educador não se fixar no lugar de mestre, nem mesmo de saber. Permite uma circulação discursiva, possibilitando ao educador operar em sua função, de forma pontual, com o objeto a no lugar diretor, tendo o saber e a verdade sob a barra, abalando a crença filosófica e pedagógica na aprendizagem plena de sentido. Crença em um saber completo, uma verdade absoluta, sustentada pela aquisição de conhecimentos, podendo assim operar a partir da lógica do impossível. Que nessa circulação discursiva o educador também possa circular de um discurso ao outro nas ocasiões que sua função reclamar pelas várias tarefas, não se instalando no discurso do mestre.

\footnotetext{
“A educação elimina a possibilidade de advir o errante, aquele que pode vagar diante das certezas em busca de sua própria produção" (FILHO, 2001, p. 96).
}

A psicanálise, na sua interlocução com a educação, talvez não tenha muito a dizer, a responder, nem mesmo a compreender. Mas certamente tem algo a escutar. É a partir do seu lugar de escuta tanto daqueles que estão na árdua tarefa de educar, como dos impasses e embaraços que permeiam o campo da educação, podendo assim fazer uma leitura a partir do 
seu discurso e sustentando sempre uma pergunta quanto ao mal-estar que perpassa a educação, que uma aposta pode ser feita. $\mathrm{O}$ atravessamento e a experiência do discurso psicanalítico permitem o tropeço, o embaraço, o não-saber. "Colocar-se no ensino na posição de analista difere do mestre que não sai da posição de saber. Ao analista é possível não saber, gaguejar, balbuciar e não responder à demanda" (VIDAL, 2001, p. 52). Ao educador, operando em sua função, pontualmente com o objeto a no lugar diretor, ou seja, sustentando essa dimensão do enigma, da falta, do furo, não como o detentor do saber, mas, sim, como aquele que traz o conhecimento, a informação a partir de uma pergunta quanto ao desejo, também é permitido claudicar, vagar errante diante das certezas. Ao educador avisado do lugar que ocupa a partir do fenômeno da transferência, atento ao seu lugar de suposto saber no ato educativo, assim como de que para operar desse lugar é preciso sustentar uma pergunta, também é permitido não responder à demanda trazendo a possibilidade de subjetivação e da construção de um saber próprio pelo aluno.

À psicanálise, nessa interlocução, cabe escutar os significantes trazidos pelos educadores, escutar seu embaraço, seu vacilo, seu fracasso e intervir, a partir de seu discurso. A aposta que se faz é que a partir da passagem pelo discurso analítico numa circulação discursiva seja possível fazer um corte na busca incessante por um conhecimento acumulado sobre a verdade, um corte radical que possa, de alguma maneira, subverter a relação da educação com o saber e trazer um significante novo, ou pelo menos revelar uma nova perspectiva à educação, permitindo que novas perguntas possam ser inventadas, principalmente quanto à formação do educador. 
Educação: Ensino e/ou Transmissão?

Os giros discursivos e a formação 
Em psicanálise, ensino, transmissão e formação são significantes que se articulam, enodam-se, não sendo possível falar de um sem falar dos outros dois. Mais uma vez trago a fala de Jacques Lacan, tão repetida no meio psicanalítico, muitas vezes de forma banal e sem o devido rigor que ela comporta: "o ensino da psicanálise só pode ser transmitido de um sujeito a outro através de uma transferência de trabalho" (LACAN, 1964, p. 23). Embora aqui não apareça a palavra formação, ela está aí, oculta, nas entrelinhas da transferência de trabalho. Ensino e transmissão são campos fundamentais para a formação do psicanalista que, ao mesmo tempo, trazem uma conjunção e apontam para uma separação no percurso dessa formação.

Freud, preocupado com a transmissão da psicanálise, seu ensino e sua prática, receoso quanto aos rumos que esta poderia tomar e com a formação dos analistas, cria a IPA, associação que se torna responsável por zelar pela psicanálise no mundo. Porém, como nos aponta Moustapha Safouan (1985), diante da iminência da morte de Freud, em decorrência de seu câncer, tem-se início uma corrida na tentativa infrutífera de regulamentar, diplomar, institucionalizar e titular os psicanalistas e a psicanálise, na busca de garantir a posse desse legado, assim como uma busca por legitimar e dar reconhecimento ao psicanalista. E diante dessas tentativas dos próprios psicanalistas de tornar a psicanálise um "anexo da psiquiatria", frente aos desvios e às mais variadas formas de retificar o texto, os conceitos e os fundamentos que sustentam essa prática, Freud, mais uma vez, não cede e retorna ao discurso psicanalítico, à ética da psicanálise e a seu desejo, sustentando sua posição frente à causa psicanalítica, assim como a posição de sua prática, ou seja, uma posição marginal. Ao se debruçar no trabalho do texto sobre "Psicanálise e Medicina - Análise Profana", Freud recoloca a psicanálise nos trilhos, denuncia os desvios e acentua o lugar preciso da formação do analista e da transmissão da psicanálise.

Já em Freud, nesse texto da "Análise Profana", verdadeiro tratado sobre a questão da formação, do ensino e da transmissão da psicanálise, encontramos os germes do passo que posteriormente pode ser dado por Lacan quanto à formação do analista.

A novidade instaurada no campo psicanalítico por Lacan recai justamente na questão da formação do analista e na transmissão da psicanálise. E para dar partida a esse ponto da interlocução que se pretende neste ensaio, entre Psicanálise e Educação, ou seja, o ponto que se refere ao ensino e transmissão da psicanálise, na formação do analista, cabe-nos pensar o quê dessa novidade pode também ser recolhido pelo campo educacional e servir à educação e à formação do educador. 
De partida torna-se imprescindível situarmos aquilo que é da ordem do ensino e o que se coloca no terreno da transmissão. Ou seja, ensino e transmissão não dizem a mesma coisa, ou não têm o mesmo significado para o campo psicanalítico. Ensino e transmissão apresentam-se como dois campos essenciais para a formação do analista, porém campos distintos, que ao mesmo tempo revelam uma conjunção, não se apresentando um sem o outro, assim como também revelam uma disjunção, uma separação fundamental nessa formação.

Freud já aponta, desde muito cedo em sua obra, que a formação do analista não se limita ao estudo teórico dos conceitos e do texto psicanalítico. Não basta ter um vasto conhecimento teórico da psicanálise, um estudo formal de toda a obra para assim ter garantias de um título de psicanalista. Para Freud, a formação do analista está ancorada no tripé do estudo teórico, análise pessoal e supervisão. Assim como não basta apenas o estudo teórico para tornar-se analista, também não basta a experiência na carne, a passagem pelo divã. A isso soma-se a supervisão, ou controle, como inicialmente era nomeado esse endereçamento a um psicanalista mais experiente para se trabalhar questões da clínica que trouxessem embaraços para o analista iniciante.

Assim, o funcionamento da IPA, associação responsável pelo futuro da psicanálise, era pautado em regras administrativas, com caráter acadêmico e sustentado em relações hierárquicas e burocráticas. A análise didática, nome dado à análise daquele candidato à analista, feita com um analista mais experiente, por um tempo previamente determinado, o controle e os seminários que ali eram ministrados traziam esse caráter de certa verificação de uma adequação para exercer a função de analista. Ou seja, era somente depois de passar por essas "instâncias” de regulamentação e controle, e só assim, chegava-se a se tornar analista.

É neste contexto que Freud escreve dois de seus textos mais polêmicos e criticados, inclusive no campo psicanalítico, que trazem questões importantíssimas quanto à formação do analista e o lugar da psicanálise na cultura. Ao escrever "Deve a psicanálise ser ensinada na universidade?", artigo de 1919 que traz em seu título já uma questão, Freud situa com rigor que o lugar da transmissão da psicanálise não é e nunca será a sala de aula, os seminários sobre a teoria, mas sim o divã. Neste texto, Freud afirma que o ensino teórico possibilita, sim, que se chegue a um saber sobre e a partir da psicanálise, mas não à convicção do inconsciente. Ou seja, torna-se analista somente ao fazer a experiência do inconsciente e se apropriar desse saber que da experiência decanta. Diante dos desvios que Freud vê cair a psicanálise, com o rigor tomado como rigidez e a autorização seguindo o equívoco da autoridade e da hierarquização, ele retorna ao discurso psicanalítico, à ética da psicanálise e a seu desejo de sustentar sua posição. Recoloca a psicanálise nos trilhos e se debruça sobre a defesa da análise 
leiga, da análise praticada por leigos, trazendo para a ordem do dia a questão do desejo e do saber que sustenta a prática da psicanálise.

Em "Psicanálise e Medicina - Análise Profana", Freud é taxativo ao afirmar que qualquer um que tenha feito a experiência analítica não é nenhum leigo no terreno da psicanálise. Escreve esse texto em defesa do psicanalista acusado de curandeirismo e charlatanismo, Theodor Reik, que havia sido levado ao tribunal de Viena por um de seus pacientes. Neste texto, mais uma vez, Freud traz o rigor da prática psicanalítica e da formação do psicanalista, posição que se coloca na contramão daquela que vinha sendo sustentada pela IPA. Em carta a Ernest Jones assim escreve:

“Com certeza o destino decidirá quanto à relação última entre psicanálise e medicina, mas isso não implica que não devamos tentar influenciar o destino, tentar conformá-lo por meio de nossos próprios esforços" (JONES, p. 294).

E posteriormente a Eitingon, neste momento presidente da IPA:

"Eu gostaria que o conjunto da Associação assumisse o ponto de vista que apresentei, mas isso é algo que certamente não conseguiremos. Talvez venhamos a romper nosso antigo companheirismo se nos perdermos a nossas exigências" (JONES, p. 294).

Essas duas falas de Freud trazem de forma bastante explícita sua posição quanto aos rumos e ao destino da psicanálise, assim como sua posição frente ao que essa prática vinha se tornando nos meandros burocráticos e administrativos da IPA.

Em “Análise Terminável e Interminável” (1937), Freud retoma esse ponto e tece novamente considerações sobre os rumos e o futuro da prática psicanalítica, assim como as resistências que se colocam em seu caminho. Porém traz aí, no final de sua obra e de sua vida, uma posição sem ilusões e ideais quanto aos caminhos que a psicanálise poderia tomar, mas, mesmo sem ilusões ou garantias, não cede quanto ao rigor do texto e a seus conceitos. É também neste texto que Freud retoma o que já havia pontuado em 1925, colocando a psicanálise na série das profissões impossíveis, escrevendo assim:

\footnotetext{
"Quase parece como se a análise fosse a terceira daquelas profissões ‘impossíveis' quanto às quais de antemão se pode estar segura de chegar a resultados insatisfatórios. As outras duas, conhecidas há muito tempo, são a educação e o governo" (1937, p. 265).
}

E, mais uma vez, Freud sustenta a formação do analista pela via da análise pessoal ao trazer a pergunta sobre onde pode um aspirante à psicanalista "adquirir as qualificações ideais de que necessitará em sua profissão? A resposta é: na análise de si mesmo, com a qual começa sua preparação para a futura atividade" (idem).

Porém é Lacan quem vai novamente trazer para a ordem do dia as questões quanto à formação do psicanalista e à transmissão da psicanálise. Quando, em 1964, diante da situação 
delicada em que se encontrava a psicanálise na França e a partir de sua saída da IPA, tratada por ele como uma "excomunhão", Lacan, que já ministrava seus seminários e sustentava um lugar na transmissão da psicanálise, retorna aos conceitos fundamentais da psicanálise, fazendo uma correção de rota quanto aos desvios no campo psicanalítico e funda, num ato, a Escola Freudiana de Paris.

Situa a Escola na Ata de Fundação da Escola Freudiana de Paris como "um organismo onde deve cumprir-se um trabalho, (...) que, através de uma crítica assídua, denuncie os desvios e os compromissos que amortecem seu progresso, degradando sua utilização" (LACAN, 1964, p. 17). Lacan recoloca o acento da formação, do ensino e transmissão da psicanálise no funcionamento institucional, que estará pautado na experiência, na qual o que se impõe ao praticante é que ele se responsabilize por sua formação, sendo exigência ética que este assuma os riscos de sua experiência, tornando nulos os simples hábitos, promovendo uma disjunção entre poder e saber, colocando em suspensão a hierarquia e pautando o funcionamento na noção de gradus.

"O gradus é conforme a capacidade que se mostra de fazer a Escola progredir. Ele não se confunde com um grau hierárquico. Mas se há ruptura, não há supressão da hierarquia. Vocês podem apreciar, ao contrário, o poder posto nas mãos daqueles que trabalham" (LACAN, 1967, p. 24).

O poder é colocado nas mãos daqueles que trabalham, que endereçam seu trabalho à Escola e que sustentam ali sua formação. Nessa lógica, o percurso próprio, de cada um, assim como o desejo, está em campo, fazendo marca e dando a direção do trabalho na formação. Aqui também podemos retomar um primeiro princípio posto por Lacan para dizer da formação do analista e da transmissão da psicanálise, ao dizer que "o psicanalista só se autoriza por si mesmo" (1967, p. 29). E, ao autorizar-se por si mesmo e mais alguns outros, como posteriormente Lacan enunciará, ele se torna "responsável pelo progresso da Escola, torna-se psicanalista de sua própria experiência" (idem). Assim está em campo a questão da responsabilidade e da autorização e não mais do poder e da autoridade. É o gradus e não a hierarquia, o poder e a organização administrativa e burocrática que dá a direção.

A Escola não garante a formação, muito menos dá garantias ao psicanalista. O que ela pode garantir é a relação do psicanalista com sua formação, ou seja, garantir o trabalho, e zelar pelo funcionamento. A Escola se abre para aqueles que se interessam pela psicanálise em ato e é nesse lugar que podem colocar à prova seu interesse. Sendo assim, a Escola não se limita à formação de analistas, embora seja o lugar da formação por excelência. A Escola não é constituída apenas de analistas e se dirige também àqueles que se interessam pela psicanálise em ato. Eduardo Vidal adverte que "a Escola destina-se ao não-analista, como 
sendo aquele que ainda não foi afetado pelo esquecimento do ato que o decidiu na sua opção de analista, pois ele se encontra no tempo da passagem" (2001, p. 45). Posteriormente, em 1967, Lacan redigirá a Proposição sobre o psicanalista da Escola, onde tece as bases desse lugar de formação.

\footnotetext{
“Trata-se de uma Escola, e não de uma Escola comum. Se vocês não são responsáveis por ela, cada qual diante de si mesmo, ela não tem nenhuma razão de ser. E a responsabilidade essencial da Escola é fazer avançar a psicanálise, e não constituir uma casa de repouso para os veteranos" (LACAN, 1967, p. 22).
}

Retomemos a fala de Lacan que nos norteia aqui nesta tentativa de brevemente trazer essa articulação entre ensino e transmissão da psicanálise e formação do analista. "O ensino da psicanálise só pode ser transmitido de um sujeito a outro através de uma transferência de trabalho" (1967, p. 23). E prossegue, “os 'seminários', inclusive o nosso curso de Hautes Études, nada fundarão caso não reenviem a essa transferência” (idem).

A formação só se dá sob transferência, a partir desse reenvio a essa transferência de trabalho. Tal transferência convoca ao trabalho e faz uma exigência ética a cada analista para que este responda por sua prática, por sua clínica e por sua formação, pagando com a palavra, implicando aí sua presença como sujeito, dividido, subjetivado, desejante. Tal transferência exige, nessa convocação, que cada um possa se responsabilizar por essa empreitada, assim como pelo funcionamento institucional.

Lacan instaura, neste funcionamento, os dispositivos do Cartel e do Passe, que se fundam na Escola e que são a base da transmissão da psicanálise neste lugar. Não podemos falar de Escola, nem mesmo de formação e transmissão sem lançarmos mão desses dispositivos. Lacan situa o Cartel como órgão de base da Escola, lugar de trabalho a ser realizado a partir de um pequeno grupo, composto de três a cinco pessoas, sendo quatro a medida certa, e mais-uma que será responsável e encarregada de zelar por esse trabalho, por sua direção e seu destino. Este deverá ter a duração de um ano, no máximo dois, para evitar os efeitos de grupo, de cola, e terá ao final, como efeito, um produto, em forma de um escrito, e que seja um produto próprio, de cada um, no qual cada um deverá por algo de seu. O cartel é, dessa forma, um lugar privilegiado de transmissão, ou seja, é o núcleo da transmissão do saber psicanalítico. Sendo assim, o cartel, a partir dessa lógica outra de trabalho, dissolvendo os efeitos de grupo, reenviando a questão ao texto, colocando em campo a transferência de trabalho, permite um funcionamento outro na comunidade de analistas. $\mathrm{O}$ cartel tem a função de fazer a dobradiça entre intensão e extensão, e para que nesse enlace cada um possa, a partir 
de sua experiência, considerando que a intensão funda a extensão, colocar-se, falar e produzir um trabalho próprio, fazendo decantar um saber.

O dispositivo do Passe diz do final de análise, da passagem de psicanalisante a psicanalista, onde o analista precisa dar provas do seu desejo, do desejo do analista, assim como de sua prática, de sua posição na direção de cura das psicanálises conduzidas por ele. E o final de análise concerne na relação do analisante com sua análise, com a liquidação da transferência e com o desejo do analista. Não abordaremos aqui tais procedimentos de forma mais elaborada, primeiro por não ser essa a finalidade desse ensaio e segundo porque, por se tratar de conceitos e procedimentos peculiares, singulares do campo psicanalítico exigem um detimento, um rigor e um percurso bastante extensão pelo texto lacaniano, no qual ainda preciso avançar.

Mas o que nos interessa aqui a partir desses procedimentos postos para a formação do psicanalista, assim como com relação ao ensino e transmissão da psicanálise, é justamente aquilo que nessa formação há de subversão. Jean-Guy Godin, ao retomar Lacan quanto à formação do analista, vai dizer que "a análise não forma. Nos melhores casos produz uma conformação nova do inconsciente" (GODIN, p. 107). E que Lacan nunca falou de formação analítica, mas, sim, de formações do inconsciente. Traz aí a subversão que nos interessa na formação. A formação do analista está aí colocada na série das formações do inconsciente, na mesma cadeia que os sonhos, atos falhos, chistes e sintomas. A formação está, dessa forma, articulada no triplo registro prática-clinica-ética e sendo assim se coloca como um conceito fundamental para o analista. Se a análise não forma, se somente ela não basta, sem ela também não há analista, não há transmissão. Sem sua prática, sem a intensão, sem sua clínica, sem a condução de análises na direção da cura, e sem sua ética, que faz a amarração entre prática e clínica, não podemos falar de formação do analista.

Formação, no dicionário, apresenta-se como ato, efeito ou modo de formar; constituição, caráter; modo por que se constituiu um corpo de tropas. Refere-se a formal. Significa evidente, manifesto, genuíno, convencional. Assim como formar, dar forma a algo, ter a forma de algo, conceber, imaginar, pôr em ordem, em linha, educar, fabricar, fazer, constituir, tomar forma, concluir curso universitário... Outras tantas palavras derivam da formação, trazendo seu radical; formal, formatação, formatar, formato, formalizar, formando... Porém, para o campo psicanalítico, outra formação está em campo. Para esse campo o que se põe em questão na formação é essa significação primeira, da formação como ato, como efeito, modo de formar. Se é ato, efeito, modo, essa formação não se dá dissociada da subversão que se coloca quanto ao discurso psicanalítico. 
Todavia, a Escola não garante o analista, como apontamos. A garantia oferecida pela Escola é apenas a da relação do analista com sua formação. Porém, se a formação do analista é, por excelência, mais uma formação do inconsciente e só há na articulação clínica-práticaética, então uma exigência ética se coloca também na extensão, no ensino e transmissão da psicanálise, ou seja, que o analista também ali pague com sua palavra. É somente assim que o texto dessa formação pode ser lido, não como uma comunicação da fala, mas, sim, a partir dos deslocamentos do discurso.

Pagar com a palavra na extensão não é sem embaraços, sem equívocos, sem tropeços. É dar a ver, não no sentido da mostração, mas sim da verificação, de dar provas, do seu desejo, o desejo $\mathrm{X}$, sendo a prática, também na extensão, uma prática da transferência, da transferência de trabalho. Aí está a subversão proposta por Lacan a partir do discurso analítico, que a formação do analista não se estabeleça em responder a demanda, mas em privilegiar o desejo e convocar ao trabalho.

A transferência de trabalho, endereçada à psicanálise e não ao psicanalista, dirigida e sustentada pelo texto psicanalítico, desaloja o sujeito da posição de saber e faz cair por terra os efeitos imaginários da transferência analítica. Moustapha Safouan (1985) nos adverte que “a experiência da Escola prova, em todo caso, que a psicologia de grupo, ela não muda. No máximo pode-se frear seu desenvolvimento" (p. 63). Os efeitos imaginários do grupo sempre estarão presentes também na Escola, neste lugar de formação do analista. Porém o que se espera a partir dessa crítica assídua dos desvios é que se possa relançar as demandas de ensino à transferência de trabalho, fazendo assim uma torção, e a partir do manejo dessa transferência poder privilegiar o funcionamento.

Dessa forma, só há trabalho, formação, ensino e transmissão da psicanálise se estes forem impulsionados por uma causa, ou seja, pela causa de desejo. E o que se espera é que nesse trabalho cada um possa colocar algo de seu, deparar-se com a novidade trazida pelo desejo, com o ineditismo que emerge desse saber. Caso contrário, o trabalho torna-se um trabalho servil, trazendo como produto uma caricatura de analista. Quando um analista se coloca no ensino e na transmissão como responsável pela formação de seus analisantes numa Escola ou mesmo simplesmente daqueles que se colocam ali a escutá-lo, em qualquer campo de interlocução, estamos na dimensão do engano. Ao analista na extensão, ao colocar-se no ensino e transmissão da psicanálise, cabe fazer valer o discurso analítico, ou seja, deslocandose da posição de saber, promovendo a descontinuidade necessária ao avanço da psicanálise, o descentramento que não permite o fascínio e faz circular o saber e o descompletamento que 
impede os efeitos de grupo e permite que cada um possa falar em nome próprio, colocando algo de seu e reinventando a psicanálise.

Ensino e transmissão são então conceitos fundamentais na extensão da psicanálise. Como dito anteriormente, embora exista uma conjunção entre eles, são conceitos disjuntos, que num movimento lógico apontam para uma separação.

O ensino se realiza através dos seminários, dos núcleos de trabalho, dos grupos de leitura. $\mathrm{O}$ ensino traz o texto, o saber referencial, veicula os conceitos, burila a tradução. $\mathrm{O}$ ensino, de certa maneira, acrescenta, veicula a informação. Já na transmissão do que se trata? A transmissão é sempre da falta. A transmissão está remetida à castração, a esse saber nãotodo, a esse ponto do impossível. A transmissão se dá pela posição daquele que transmite, pelo lugar que ele ocupa frente ao saber, por sua posição dividida, por sua submissão à castração, pelo significante. $\mathrm{O}$ que se transmite está para além daquilo que se ensina, ou mesmo daquilo que se ousou transmitir. Como nos afirma Lacan, a transmissão é a herança que se deixa, herança simbólica, e sendo assim só há herança da castração, e só há transmissão dessa falta, falta estrutural. Para que haja transmissão é preciso que o sujeito se saiba castrado e faltoso, é preciso ser marcado pela barra da castração e, somente a partir dessa posição, poder transmitir.

Se o que se transmite é a falta, é esse saber não-todo que sustenta uma transmissão e não um saber pronto, acabado, garantido, não se sabe a priori que se transmite algo e da transmissão só temos notícias a partir de seus efeitos.

Mas ensino e transmissão se articulam. Existe uma interseção entre eles que se produz no trabalho da Escola. Lacan adverte que Escola não depende do ensino, "já que ele prossegue lá fora” (1964, p. 24). Ele prossegue, sim, lá fora, em lugares outros onde se fala e veiculam os conceitos psicanalíticos. Porém na Escola, lugar por excelência para a formação do analista, o ensino faz interseção com a transmissão. No esquema trazido por Maria Cristina Vidal no texto "Sobre o ensino na Escola", podemos ver que do lado do ensino situam-se os seminários e mesmo a sessão clínica, e do lado da transmissão, estão os dispositivos propostos por Lacan do Cartel e do Passe. Porém, na interseção, o que se evidencia é o estilo, o ponto que traz a marca do sujeito frente à causa psicanalítica, sustentado por seu desejo e que o coloca, nesta posição forçado a reinventar a psicanálise.

O ensino da psicanálise pode, sim, ter efeito de transmissão, a partir da posição daquele que se coloca a ensinar, posição marcada pelo desejo. Algo ali pode se transmitir. Lacan propõe que aquele que se põe a falar em nome da psicanálise esteja nesse lugar na posição de ensinante. Ensinante, fazendo uma junção entre os lugares daquele que ensina com 
a posição do analisante, daquele que está no trabalho de análise, submetendo-se à regra fundamental e que se põe a associar livremente. "O ensinante aceita o desafio de dizer, sem saber o que diz, colocando em ato a função da falta inerente à palavra" (VIDAL, 2001, p. 59). Porém, a posição do ensinante difere da posição do analisante, pois o primeiro está avisado do não saber, e ele não fala livremente, ele tem aí, nesta função, como baliza, os articuladores "lógicos da teoria psicanalítica" (idem).

Num dos dicionários de nossa língua, temos como definição de ensino a "transmissão de conhecimentos, instrução"; de transmissão, encontramos o "ato ou efeito de transmitir(-se); transferência". Transmitir se define por "mandar de um lugar para outro, ou de uma pessoa para outra; expedir; fazer passar dum ponto, ou dum possuidor ou detentor, para outro; transferir; deixar passar além; conduzir".

Ou seja, há, ou pode haver, efeito de transmissão no ensino. Assim como quando se transmite, deixa-se passar além, conduz-se a um ensino.

E que relação tem toda essa discussão com o campo educacional? O que podemos tomar aqui da experiência de saber psicanalítica que possa servir ao campo educacional, no que se refere à formação do professor/educador?

Se para falarmos de formação no campo da psicanálise é preciso trazer para a ordem do dia as questões quanto ao ensino e transmissão, como podemos abordar tais conceitos no campo da educação? Poderíamos pensar a educação como ensino e/ou transmissão? Por que colocamos aqui as conjunções dessa maneira, e/ou? Será que, como na psicanálise, também na educação podemos pensar esses dois conceitos fazendo uma interseção? Se pensarmos dessa forma um não exclui o outro e haverá aí também efeito de transmissão no ensino educacional.

Como pudemos abordar no ensaio introdutório desse trabalho, o campo educacional sempre esteve ligado, desde os primórdios da civilização, ao ensino. A educação é o campo, por excelência, do ensino, no qual são ensinados conteúdos, conhecimentos, conceitos. Ensina-se esse saber teórico, referencial, que se acumula, adquire-se e se aprende. Ou seja, a educação tomada pelo viés do imaginário, no qual os métodos e técnicas de ensinoaprendizagem vigoram, no qual a qualificação, a avaliação, a didática e as metodologias são o carro chefe e dão a direção do ensino. Aí se situa a Pedagogia, a ciência da educação por excelência. Entretanto, educar não se faz sem o nó do imaginário.

Porém quando tomamos a educação como função que se faz em ato, quando a situamos para além do simples ensinar, instruir e promover a capacidade intelectual e cognitiva, para além da aquisição de conhecimentos práticos ou teóricos, ou seja, quando a 
situamos a partir do significante "criação", ela deixa de dizer apenas do ensino e se coloca também no terreno da transmissão. Ao situar a educação para além do nó do imaginário, enlaçamos aí o nó do simbólico, da educação como prática cultural, da educação como função, da educação perpassada pela tradição. E se a educação é função que se faz em ato, ela então se transmite. Educa-se para além da Pedagogia. Educar não se dá também sem o nó do simbólico.

Mais um nó se enlaça aí, o nó do real, fazendo um triplo registro também no campo da educação. Porém esse nó é enlaçado a partir da leitura feita pela psicanálise da educação como prática impossível. É preciso situar a educação como prática que toca o real e apontá-la marcada pela falta, por aquilo que escapa, por um resto ineducável; educação tomada pelo viés da transmissão.

A partir dessa lógica, de pensar a educação a partir da posição daqueles que se colocam nessa árdua tarefa de educar, tomando a educação como uma prática, um ofício perpassado pelo impossível, pela falta, por isso que escapa, podemos dizer que também na educação, mesmo quando o ensino dá a direção do trabalho, é possível se ter efeitos de transmissão. Como pudemos trabalhar nos ensaios anteriores, só há transmissão sob transferência e podemos também dizer que para que haja ensino também é preciso que haja transferência. Para que este tenha efeito de transmissão é preciso uma torção que possibilite que a demanda de ensino seja reenviada a uma transferência de trabalho. E para tal é preciso que o professor/educador esteja atento ao fenômeno da transferência na sua prática.

Se a transmissão é da falta e sustentada pela transferência, se o ensino baseia-se na exposição teórica, no saber referencial, mas também não está fora do campo da transferência e pode ter efeito de transmissão, este ensino também é marcado pela impossibilidade. Ao retomar aí os ofícios impossíveis e acrescentar a psicanálise, podemos colocar a educação neste mesmo terreno, onde há a emergência do real, do real da castração. E sendo a educação também uma prática impossível, onde a falta está em causa e essa topada com o real é inerente, inevitável, a transmissão está em campo. Ensino e transmissão também no campo educacional fazem interseção e o que cai, o que resta desse buraco da interseção é o estilo do professor/educador.

Mais uma vez é preciso salientar que não se trata aqui de fazer uma transposição da formação do analista e da transmissão da psicanálise para o campo educacional. O ensino, vetorizado pelo saber teórico, referencial, pelos conteúdos e pelo conhecimento, exige, sim, métodos, técnicas, didáticas, artifícios, recursos. Mas, novamente, a aposta que se faz aqui é de lançar um olhar sobre a posição do educador, que não desperta a transferência, mas se 
coloca como objeto desta, e que a partir de sua posição decidida e dividida, possa fazer circular o significante de uma transmissão, ou seja, do seu estilo.

Contudo, sustentar tal posição não é algo tão simples, principalmente por não ser esse o discurso veiculado no campo educacional. Porém o atravessamento pelo discurso psicanalítico possibilita, oferece recursos para sustentar essa posição, e essa é a aposta que vem sendo feita ao longo desse ensaio.

A psicanálise instaura na cultura um novo discurso, que faz corte, que aponta o furo na racionalidade, um sujeito estrangeiro em sua própria morada, discurso que, embora inédito, não é sem consequências tanto para aqueles que se submetem aos seus significantes, quanto para a comunidade de analistas e para a cultura. Lacan traz em "O Seminário: livro $17-O$ avesso da psicanálise” a pergunta quanto “o que é que o analista institui?” (1968/69, p. 33). A psicanálise é uma prática discursiva e o discurso psicanalítico traz o real como seu operador, intervindo neste real. $\mathrm{O}$ analista, ou o discurso psicanalítico, institui não só uma nova e inédita prática, mas também a possibilidade de fazer uma leitura outra dos demais discursos que já perpassavam a cultura. Freud, ao deixar falar a histérica, não se colocando aí, nesta escuta, no lugar de mestre almejado por ela, ao atentar sua escuta para a "cadeia de reminiscências" ou "cadeia significante" como chamará Lacan, faz uma intervenção precisa no discurso trazido por ela e instaura a posição do analista. É a histérica, a partir de seu discurso, que permite a inscrição da psicanálise na cultura, possibilitando uma leitura outra não só deste, mas também dos demais discursos que a perpassam. O discurso psicanalítico traz essa subversão quanto à verdade e ao saber, provocando uma ruptura, um corte epistemológico na cultura.

Lacan retoma os impossíveis de Freud tratando-os como discursos, e assim dedica todo um seminário, intitulando-o "O avesso da psicanálise", para trabalhar tais discursos. Eles são quatro. Sua estrutura tem também quatro pés, quatro termos, quatro lugares. O Discurso do Analista (DA) articula-se com a impossibilidade de psicanalisar; o Discurso do Mestre (DM) que faz referência à impossibilidade de governar; o Discurso Universitário (DU), referindo-se à impossibilidade de educar. E Lacan acrescenta um quarto discurso, o Discurso da Histérica (DH), discurso inaugural da prática analítica, que faz referência à impossibilidade de se histericizar, de se fazer desejar. Neste seminário, Lacan vai situar a psicanálise como uma experiência de discurso, uma prática discursiva. E aponta aí, nesta prática, o saber articulado ao gozo, ao real e à impossibilidade de apreendê-lo totalmente.

São quatro os termos, os elementos dos discursos. S1 é o significante unário, significante mestre, primordial. É o significante que dá a partida, que funda o inconsciente. S2 é o significante binário, lugar da bateria dos significantes, lugar do Outro, do saber, do 
gozo. \$ é o sujeito barrado, dividido, é o sujeito do inconsciente. É a barra que distingue o sujeito do inconsciente do indivíduo vivo, que o constitui como dividido, de um corpo marcado pela linguagem. O \$ aparece no intervalo entre S1 - S2. a é o Objeto a, quarto termo colocado no discurso para marcar sua estrutura quaternária. É o objeto, elemento que é real e não significante, perdido para sempre, o horror da castração. $\mathrm{O}$ a aponta para essa forma de tratar o gozo e, por isso, a importância do lugar ocupado por esse elemento em cada discurso. É a posição do objeto a no discurso que vai marcar a forma de gozo. Tais elementos se alternam nos quatro lugares fixos do discurso. Lacan escreve os discursos na fórmula algébrica dos matemas ${ }^{15}$. Os elementos giram numa direção dada, num certo sentido e ao ocuparem esses lugares fixos determinam a forma de gozo. Sendo assim, os discursos são modalidades de gozo e "sua lógica aponta para os laços sociais possíveis entre o sujeito e o outro" (WAINSZTEIN, 2001, p. 15). Os discursos fazem falar, cada um à sua maneira e, dessa forma, cada um tem como efeito uma produção específica.
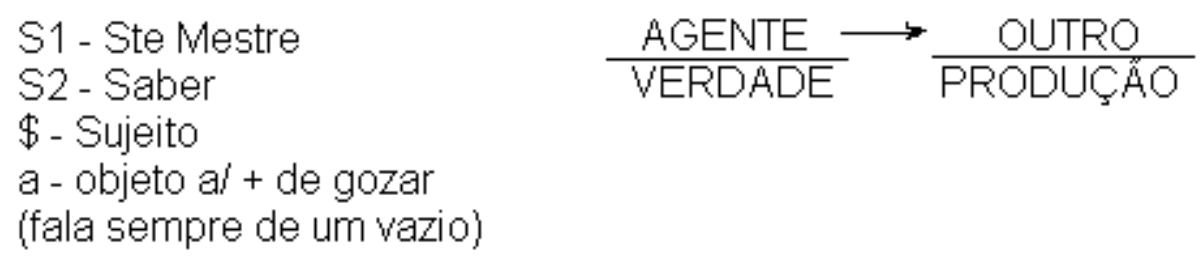

O discurso é feito de letras, como aquilo que não se lê. Os quatro discursos se organizam em torno desses quatro lugares, que começam pelo AGENTE que se dirige ao OUTRO (também lugar do saber e do gozo), tendo a VERDADE e a PRODUÇÃO sob a barra. São os elementos que circulam, que se deslocam nos giros discursivos. Os lugares são fixos e, a cada $1 / 4$ de giro, temos assim a passagem para outro discurso. E nesse giro dos elementos, ao ocupar lugares distintos, sua função no discurso também se altera. Sendo assim, a partir de um discurso, pode-se obter os outros três, tomando a mudança de posição dos elementos nos lugares do discurso. Assim, o que está em questão é a circulação discursiva. Um sujeito que enuncia um discurso passa, necessariamente, "por todos e por cada um deles" (AMIGO, 2001, p. 75).

\footnotetext{
"Se parece legítimo que a cadeia, a sucessão de letras dessa álgebra, não pode ser desarrumada, ao nos dedicarmos à operação de quarto de giro, iremos obter quatro estruturas, não mais, das quais a primeira lhes mostra de algum modo o ponto de partida." (LACAN, 1969-70, p. 13)
}

\footnotetext{
15 “Um matema é um meio de se poder ensinar, algo que se pode transmitir. No campo da Psicanálise, é uma tentativa de transmitir o real da estrutura que o discurso suporta." (WAINSZTEIN, 2001, p. 15)
} 
É a partir da incidência do Discurso do Analista que há a possibilidade de se fazer a leitura dos demais discursos existentes na cultura. Para Lacan, discurso não é o mesmo que linguagem, nem o mesmo que palavra. E ao postular que o inconsciente é estruturado como linguagem, vai afirmar que na análise ele se ordena em discurso. Os discursos se definem pelo lugar diretor, lugar dominante, que é sempre o lugar do agente.

O primeiro dos discursos, inaugural na cultura, é o Discurso do Mestre (DM).

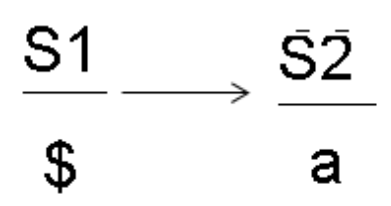

Este é o discurso do inconsciente. Nele S1, o significante-mestre, está no lugar de agente, no lugar diretor, é o saber como agente. S1, significante-mestre, representa o sujeito pra outro significante. No lugar do Outro, tesouro do significante, está o saber (S2). Porém, Lacan vai afirmar que este discurso não conduz ao saber. O que se produz nesse discurso é um saber teórico.

\footnotetext{
"Nesse discurso o sujeito se encontra ligado, com todas as ilusões que comporta, ao significante-mestre, ao passo que a inserção no gozo se deve ao saber". (LACAN, 1969-70, p. 97)
}

Ao Discurso da Histérica (DH), chega-se a partir de $1 / 4$ de giro dos elementos no discurso.

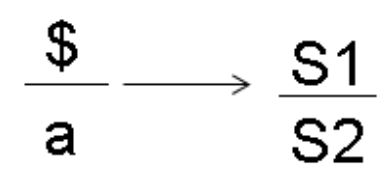

Neste discurso é o \$, sujeito dividido, que está no comando, que dirige uma demanda a um significante que representa o mestre (S1). O significante-mestre está alojado no lugar de suposto saber da verdade desse sujeito e, dessa forma, a partir desse endereçamento, o sujeito pode produzir um saber a partir de seus próprios significantes, que vêm a tona na associação livre. Porém, o saber que se produz aí é um saber inconsciente, que não basta para dar conta da verdade do sujeito. O Discurso da Histérica é o discurso do analisante, por excelência, daquele que fala a partir de sua divisão. Discurso que, na cultura, sempre esteve dirigido ao mestre, mas que, a partir da inauguração de um novo discurso, o do analista, funda a psicanálise.

Mais $1 / 4$ de giro e chega-se ao Discurso do Analista (DA). 


\section{$\frac{a}{S 2} \longrightarrow \frac{\$}{S 1}$}

Nele o Objeto a está no lugar diretor e o analista se situa aí, fazendo semblante desse objeto, exercendo a função de causa do desejo, possibilitando que o saber do sujeito advenha como verdade. Para que esse saber seja verdadeiro, verdade com estrutura de ficção, é preciso que esse saber seja novo, inédito. O saber produzido aí é o saber textual, saber próprio de cada sujeito, que traz o texto inconsciente e porta essa novidade.

O Discurso do Mestre produz como efeito, o Discurso Histérico, porém não o institui como tal. O que o institui de fato, em ato, é o Discurso Analítico. É a partir desse discurso histérico, que já estava aí, presente na cultura como efeito do discurso do mestre, que Freud institui o discurso analítico, nesse suposto saber da verdade. É o encontro da histérica com Freud que possibilita a psicanálise. É a isso que Foucault se refere ao situar a invenção freudiana como fundadora de discursividade.

O Discurso da Histérica é um produto da neurose e já estava presente aí, na cultura, muito antes da psicanálise. Ela, a histérica, endereça seu discurso, sua demanda, à ciência, ao mestre, ao médico, nesse me diga sobre minha verdade. Porém, é somente com a intervenção e a invenção freudiana, ao instituir esse discurso em ato, que este pode ser escutado pelo analista. É somente porque Freud escutou algo aí, neste discurso, nessa demanda, nessa repetição de saber, sem retornar à posição de mestre, sem responder à demanda, mas, sim, fazendo uma torção, colocando-se como analista, que um novo saber pode ser produzido. Para que haja uma produção de saber (S2) no discurso histérico, é preciso que haja uma intervenção do discurso analítico.

Assim como a transferência é um produto da neurose e não uma invenção da psicanálise, mas é recolhida por esta que a faz seu instrumento, o Discurso Histérico também não é uma invenção da psicanálise. Freud só faz lê-lo a partir de uma outra posição, desalojada desse lugar de saber sobre a verdade do outro. É uma retomada pelo avesso. O Discurso Analítico é o avesso do Discurso do Mestre. A histérica demanda ao mestre um saber, mas também denuncia, a todo instante, que este é castrado. Tanto mestre quanto saber são barrados. E "o Mestre, o que ele quer é que a coisa funcione. A emergência da subjetividade neste caso estava destinada a permanecer recalcada sob a barra" (WAINSZTEIN, 2001, p.36), já o Discurso do Analista outorga um outro lugar ao saber. 
sustentar o reinado do objeto que como causa resistirá a qualquer esforço de captura" (AMIGO, 2001, p. 84).

Já o analista não almeja que a coisa funcione, mas, ao se ocupar o lugar de semblante de a, coloca-se a ler e se presta como causa. Causa de desejo, que possibilite a emergência de um saber que porte a subjetividade, ou seja, que seja inédito e próprio de cada sujeito. Como nos indica Silvia Amigo (2001), ocupar o lugar de agente só é possível enquanto semblante. E fazer semblante é como um jogo de "faz de conta", aquela velha brincadeira infantil. E fazer de conta não é ser. E isso a criança sabe muito bem quando brinca. Fazer de conta é dar partida ao jogo, a uma elaboração. E o analista, enquanto agente, fazendo semblante de a, fazendo de conta de a, dá partida à causa de desejo. O Discurso do Analista põe em campo o desejo e tem como produção S1, significante-mestre, abrindo a possibilidade "de obter um outro estilo de significante-mestre" (AMIGO, 2001, p. 81) e o saber vem no lugar da verdade. Verdade com estrutura de ficção, verdade não toda, verdade que enuncia o saber inconsciente. Assim, verdade e saber estão disjuntos no Discurso do Analista e não colados como se apresentam no Discurso do Mestre. O Discurso do Analista é pontual, ele aparece, como salienta Silvia Amigo (2001), "em um momento punctiforme" e "comanda a produção do ato analítico" (p. 79). E por ser punctiforme, por tomar a aparência de um ponto, por ser pontual, faz um corte, marca um antes e um depois, e a passagem por esse discurso não é sem efeitos e consequências.

O Discurso Universitário (DU), obtido a partir de mais 1/4 de giro, traz o saber no lugar diretor e está na contramão do Discurso do Analista.

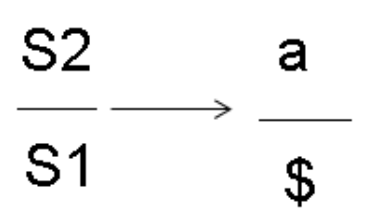

O saber aqui é um saber completo, totalizado, com base nos autores, no texto bibliográfico, nas referências. Saber que ocupa o lugar de verdade. É um saber que tampona, que se apresenta como um não querer saber sobre a divisão. No lugar da produção está o $\$$, sujeito barrado, que neste discurso é visto como produto e não como produtor de um saber próprio. Há aqui um desconhecimento desse impossível estrutural, um desmentido desse ponto de falta inaugural. Há uma exigência de tudo saber que aponta para o imperativo de não se deixar lacunas. Há uma exigência de se saber mais e de se produzir mais. Este é o discurso que aponta para a impossibilidade de educar. 
Porém não é um discurso que está cristalizado na Universidade. Ele circula também em outros lugares, inclusive na direção da cura. Numa análise o sujeito também passa pelo Discurso Universitário e há ali também uma certa apropriação do saber. Na direção da cura, o Discurso Universitário tem a função de recortar a demanda do Outro Este é também um discurso pontual. Precisa ser pontual. Mas se há uma cristalização nesse discurso, há um tamponamento pelo saber, impedindo todo e qualquer ato, inclusive o ato da transmissão, ficando o saber como absoluto e o S1, o significante-mestre, como verdade absoluta e alienante. Nas palavras de Anália Nanclares, podemos assim situar o Discurso Universitário:

\footnotetext{
"Se o discurso universitário, como o nome indica, articula a possível relação entre saber e educar, isto é, há alguém que sabe, detém o poder do saber absoluto e portanto educa outros que estariam em posição de serem 'educados', entraria em contradição com o princípio do impossível através do qual Freud definiu a tarefa de educar. Deixaria de lado, sem reconhecer, o que resta de toda relação de ensino, de toda relação do sujeito ao Outro: objeto a.

Alguém que ocupe o lugar totalizante do saber, um educador, um pai, uma mãe, deixa em posição de alienação absoluta o outro que se pretende educar." (2001, p. 114)
}

O Discurso Universitário fica ancorado na crença de educar sem resto, porém educar sem resto faz com que esse resto retorne no real. Nesse discurso do saber, o próprio saber fracassa. O resto retorna, fica escancarado pela burocracia, pela hierarquia, e o saber mostra aí seu furo. Há a tentativa incessante de tamponá-lo, porém ele insiste. Este é o discurso que hoje vigora na Educação, somado ao discurso capitalista que faz frente hoje, na cultura. $\mathrm{O}$ Discurso Universitário, associado a este outro, que não possibilita o laço, mas somente o consumo, coloca o saber na posição de bem de consumo, retirando dele seu valor de uso e lhe conferindo somente um valor de troca. Este é um discurso que privilegia a resposta e abole a pergunta. Discurso que não deseja que a coisa ande, muito menos que haja subjetivação. Discurso que espera que o sujeito (\$) produza, repita, cite, faça referência e aquilo que é próprio, seu e que faz referência à construção de seu saber fica rechaçado. E o saber que aqui se produz é um saber engessado, amarrado, vazio. E assim o Discurso Universitário fica na via da impotência, da incessante tentativa de resolvê-la. Porém, o que se trata na educação é do impossível e não da impotência. É isso que Freud vem nos revelar com a leitura feita pela psicanálise. Na educação também há um real em jogo e o impossível, como nos indica Isidoro Vegh (2001), "não é algo que se tem que resolver; o que se tem que resolver do impossível é como o sujeito vai se situar diante dele" (p. 149).

Retomando a fala de Silvia Amigo (2001) de que um "sujeito capaz de enunciar um discurso passa necessariamente pelos quatro discursos" (p. 75), podemos pensar nessa 
circulação discursiva que permite que sustentemos a afirmação "de que não há nenhum modo de viver sustentando-se em somente um deles" (idem). Nem mesmo a experiência analítica está sustentada unicamente no discurso analítico. A experiência analítica marca os momentos de passagem por esses discursos, porém, a cada giro completo, passando pelo discurso analítico, não se volta aos outros discursos da mesma maneira. Novamente recorremos à fala de Lacan quanto ao que está de fato em questão, não sendo a comunicação da fala, mas sim o deslocamento no discurso, e para que haja tal deslocamento discursivo é necessária a passagem pelo discurso analítico.

\footnotetext{
"O que é indício de flexibilidade subjetiva, o que é indício de que alguém passou ao menos por algumas voltas importantes na sua análise é que possa circular de um discurso ao outro.

Que possa governar, que possa ensinar, que possa analisar e também que possa fazer desejar, nas ocasiões em que a vida reclame por alguma destas tarefas." (AMIGO, 2001, p. 79)
}

E é exatamente isso que vimos sustentando e apostando ao trilhar esse percurso, ou seja, que a interlocução com o campo educacional possa ter efeito de deslocamento de discurso e não apenas de uma comunicação da fala, vazia, que beira o non sense. Que o analista, ao oferecer sua presença, nessa interlocução, oferecendo também a partir desta, sua escuta, sua ética e o discurso analítico, possa produzir como efeito e consequência, um deslocamento também no discurso cristalizado da educação. Assim, a partir da incidência do discurso analítico na educação, fazendo uma leitura outra, onde está em campo o impossível e onde se leva em conta o real, provocando um abalo nas certezas e verdades, pode possibilitar que um deslocamento seja feito e uma nova posição possa ser sustentada. Posição atravessada pelo discurso analítico. E nessa circulação discursiva importa a posição ocupada pelo sujeito no discurso, não havendo discurso melhor ou pior. É a permanência, a cristalização em um deles que impede o avanço.

E assim, essa é a possibilidade de interlocução entre a Psicanálise e a Educação, que o discurso psicanalítico possa fazer a amarração entre o Imaginário, o Simbólico e o Real da Educação, fazendo uma leitura outra, possibilitando essa circulação discursiva, o questionamento da posição do educador e do lugar deste no exercício de sua função.

E o que podemos extrair da formação do analista, formação onde o real está em campo e faz valer também o discurso analítico, para a formação do educador?

De forma alguma podemos extrair um modelo. Mas podemos sim extrair um ensinamento. Ensinamento de que uma formação é sem garantias. Formação está no campo da experiência, da prática. Numa formação, atravessada pelo discurso analítico, importa menos alcançar a meta, compreender o percurso, atingir os objetivos e importa mais cumprir um 
trajeto, trilhar um percurso e chegar ao final não com uma resposta, mas sim com efeitos de transmissão.

Formação não é graduação nem tempo por estudos acumulados. Uma formação que seja permanente, na qual adjetivar e qualificar estão em segundo plano e na qual seja possível extrair uma experiência. Uma formação que dê lugar sim aos métodos e técnicas, porém que estes estejam presentes para auxiliar a prática e não como seu sustentáculo. Assim, a formação do professor/educador, atravessada pelo discurso psicanalítico, pode sim seguir essa via, onde não se chegará a um final, pois a experiência não pára. Que esta, a formação, assim como a experiência, seja permanente, colocando em campo a posição e o estilo do professor e marcando um novo lugar e uma nova forma de se haver com o saber.

Para concluir, podemos pensar sim a educação tendo na sua base a transmissão, transmissão propriamente dita, da castração, da passagem pelo complexo de Édipo, da construção das teorias sexuais infantis, possibilitando a emergência desse saber sobre a falta. O ensino, a aprendizagem, a aquisição de conhecimentos sempre estarão presentes nesse campo, assim como em vários outros, e mesmo no campo psicanalítico. Porém para que a partir desse ensino se tenha efeitos de transmissão, para que um saber próprio possa ser construído por cada sujeito, é imprescindível que se sustente, na transmissão, esse lugar de falta, de não saber. A psicanálise e seu ensino podem ser apreendidos em outros lugares, que não a Escola. É possível elaborar um saber sobre e a partir da psicanálise no meio acadêmico, na universidade, na interlocução com outros campos de saber. É possível estar no ensino a partir da posição dividida, atravessada pelo discurso analítico. É possível promover na formação de professores, a partir do que ali se transmite nessa interlocução com a psicanálise, um furo no saber, uma nova questão, a partir de um significante novo que possa emergir nessa interlocução. É função do analista, não só na clínica, na direção da cura, mas também no ensino, na transmissão e na interlocução, fazer valer o saber do sujeito, o saber do inconsciente. 
Momento de Concluir 
Das Ilusões

(Mário Quintana)

Meu saco de ilusões, bem cheio tive-o

Com ele ia subindo a ladeira da vida.

E, no entretanto, após cada ilusão perdida...

Que extraordinária sensação de alívio. 
“... escreve-se, sempre, por linhas tortas."

(José Castello)

É a partir dessa epígrafe de José Castello que me coloco aqui ao fim a que este ensaio se destina. Ao fim, à sua conclusão, ao seu final, mas também à finalidade deste, onde neste emaranhado de palavras pude me colocar, colocar algo de meu e inscrever meu desejo. "Escreve-se, sempre, por linhas tortas", e nunca se sabe ao certo onde se chegará ao se colocar a escrever. Não há garantias de que aquela ideia lançada a priori, de que, a partir das primeiras linhas, se chegará àquilo que se pensou de partida. Nem mesmo há garantias de que esse desejo decidido de uma escolha feita nesse primeiro tempo se confirme no a posteriori. A conclusão que se chega nem sempre trará a resposta para a pergunta colocada no início. E, sendo assim, é o percurso que nos interessa. É seguir o fio dessa tessitura, é seguir na trilha dos significantes que emergem na cadeia e que vão dando a direção desse percurso.

"Por que escrevo? Na esperança de nesse palco, enfim, tomar meu lugar" (CASTELLO, 2010, p. 118). E é justamente dessa maneira, na esperança de enfim tomar meu lugar, que este ensaio pode acontecer. Com seus embaraços, suas lacunas, seus tropeços, mas dando prosseguimento à cadeia na qual se sustenta meu percurso, trazendo a educação como um novo significante. Esta escrita, ou seja, a escrita desse ensaio, de certa forma, representa a mim mesma. Traz aquilo que sou, meu percurso, meu desejo, minha aposta.

E que lugar tomo, enfim?

Embora seja essa uma dissertação que tem como endereço o Mestrado em Educação, não sei se é esse seu destinatário. Lacan, no escrito sobre a Carta Roubada, coloca-nos a pergunta sobre a quem pertence a carta. Se a seu remetente ou a seu destinatário. Mas logo nos responde que não pertence nem a um nem a outro. O que importa aí é o circuito, o percurso que a carta faz até chegar a seu destino. É dessa maneira que se coloca esse ensaio, não pertencendo nem a mim, uma vez que ao escrever o autor se apaga e um texto fora da gaveta, na estante, não é mais seu, mas é também de quem o lê, e não pertence também ao banco de dados desse mestrado, uma vez que o percurso feito aqui pode produzir efeitos outros para além do cumprimento burocrático para uma titulação de mestre. A passagem por esse percurso produziu efeito de sujeito, recolocando o acento da questão que me lançou a essa empreitada no lugar devido, ou seja, na psicanálise. É com certo alívio, por ter deixado cair as ilusões por esse caminho, que posso chegar, de certa forma, ao fim desse percurso.

E se a importância está no circuito percorrido, para que faça seu trajeto é preciso um tempo; tempo que é muito particular, singular, mas que também segue uma lógica. Lacan, no 
escrito "O tempo lógico e a asserção da certeza antecipada" (1945), indica-nos as instâncias do tempo que se registram no processo lógico para que seja possível chegar a uma conclusão.

Há uma instância do tempo que abre o intervalo, o instante do olhar. Esse primeiro tempo traz a possibilidade da formulação de uma questão. Diante de um problema, ou mesmo de uma inquietação, uma questão pode ser formulada. Instante, que, mesmo breve, traz uma certa decisão. Nesse percurso que aqui tem seu fim, o instante do olhar se dá a partir desse encontro com a psicanálise que relança uma luz para a questão da educação, significante que sempre esteve presente na minha vida, mas que ganha um sentido novo e entra na cadeia tomando um lugar inédito. Desse encontro com a psicanálise abre-se a possibilidade para um reencontro com a educação, e uma pergunta quanto ao que pode o psicanalista na extensão, na psicanálise em extensão, na interlocução com outros campos de saber, principalmente com o campo da educação, é lançada como uma incógnita e permitindo um endereçamento ao Mestrado em Educação. Um texto, um projeto, este sim endereçado ao mestrado, traz de certa forma essa decisão.

E José Castello (2010), ao nos trazer a distinção entre "momento" e "instante", escreve que "o momento não é comprido; um instante é mais curto ainda. A palavra instante, de significação limitada, não se usa no sentido literal. Aproveitar o instante - e não esse instante ou aquele instante” (p. 159). Castello nos dá a direção de que esse instante do olhar é preciso, pontual, é o instante que precisa ser aproveitado, daí a decisão quanto a esse ato.

Porém, diante dessa decisão, uma segunda instância do tempo se coloca, ou seja, o tempo para compreender. E nesse tempo se conjugam a necessidade de se adquirir sentido e encontrar o limite para a questão posta nesse instante primeiro do olhar. Um tempo de meditação se faz necessário. Tempo de certa parada, que também pode ser breve, limitando-se mesmo ao instante do olhar. Porém este também pode ser extenso, e sua objetividade vacilar com seu limite. Mas este é um tempo de trabalho, trabalho árduo, de elaboração da questão posta no instante do olhar, tempo que, a partir desse vacilo em seu limite, abre a via que levará adiante.

Neste ensaio esse tempo se prolongou em seu limite; tempo no qual o vacilo, a dúvida e um certo abalo na decisão estiveram no comando; tempo no qual foi necessário produzir, elaborar um texto próprio, fazer uma aposta, debruçar-se sobre conceitos fundamentais da psicanálise, articulá-los e submetê-los ao campo da educação para uma possível interlocução. Esse tempo, bastante elástico, exigiu uma parada para tentar compreender a questão posta de partida. Assim como para encontrar aqui algum sentido novo que pudesse fazer valer e sustentar tal interlocução. 
Passamos e passeamos pela transferência, pelo infantil, a sexualidade, o complexo de Édipo, a sustentação do enigma, a diferença, a queda de certos ideais, o ensino, a transmissão, a formação, a impossibilidade e trazendo o discurso analítico como articulador dessa amarração. Ou seja, ao trilhar esse circuito sustentado por uma aposta, nesse vai e vem, nas idas e vindas do texto, com seus embaraços e lacunas, apresso-me, não sem um tempo de demora, na urgência do momento de concluir. O momento de concluir vem aqui como uma luz no fim do túnel, uma "crescente iluminação de uma franja no limite do eclipse sofrido, sob a reflexão, pela objetividade do tempo para compreender" (LACAN, 1945, p. 206). Assim, ao passar o tempo para compreender e apressar-me ao momento de concluir, finalizar este ensaio "é o momento de concluir o tempo para compreender" (idem).

E nessa urgência, precipita-se. Mais uma vez é exigida uma decisão, um ato que evidencia uma conclusão. Porém, tal conclusão, embora porte uma verdade, será submetida à prova da dúvida, mas que só será verificada porque houve antecipadamente uma certeza.

Houve aqui uma certeza antecipada da possibilidade de uma interlocução entre psicanálise e educação. Uma certeza de que a partir do discurso psicanalítico é possível fazer um furo, e assim fazer circular, a partir dos demais discursos que permeiam o campo educacional, os significantes da psicanálise. Houve também uma certeza antecipada quanto a um desejo decidido de me lançar ao magistério e ao academicismo que hoje lhe é exigido.

Há, sim, uma verdade trazida pelo significante "educação" ao se encadear no meu percurso.

E o que podemos concluir afinal? Ou, o que podemos concluir ao final?

Concluímos que tal interlocução só pode mesmo ser sustentada por uma aposta. Uma aposta nos moldes daquela posta por Pascal e trabalhada por Lacan no Seminário: livro 16 De um outro ao Outro. Tal aposta, de cara, já presume uma perda. Pelo simples fato de apostar já se está pagando um preço; aposta na qual não há garantias. Não se trata de uma aposta no resultado, mas, sim, uma aposta na crença de que haverá efeitos. Que efeitos? Não podemos saber antecipadamente. Antecipada só há a certeza de que se deve apostar.

E assim concluímos, depois de trazer um pouco, um ponto, um fragmento, daquilo que da psicanálise podemos recolher e que nos permite, por uma certa analogia, estar atento a tais indicações também no campo da educação. A transferência, o infantil, o Édipo, o enigma, a formação, o ensino e a transmissão, estão também presentes no ato educativo e podem ser lidos e trabalhados no campo educativo a partir da subversão que o discurso psicanalítico lhes impõe. A aposta a que se chega aqui, ao final, é a que perpassa, atravessa, entrecorta todo esse ensaio. Aposta de que, ao tomar os significantes psicanalíticos e se endereçar, através de uma 
transferência de trabalho ao texto psicanalítico, ao permitir-se uma leitura outra a partir do discurso psicanalítico, possa haver, também na educação, a subversão, assim como há na psicanálise, dos dois significantes que lhe são tão caros: "ensino" e "mestre".

Ao dar um lugar para a transferência, podendo escutá-la e, de certa forma, trabalhá-la, ao privilegiar a pergunta, sustentando a dimensão do enigma, ao estar avisado da sexualidade na sua relação com a diferença, com a falta, a castração, ao dar lugar à diferença, ao particular, ao que há de próprio no processo de ensino e aprendizagem, ao assumir uma posição menos iludida e idealizada frente à sua função, podemos dizer que um educador e a educação fez aí uma subversão de seu ato. Há aí uma subversão na sua posição no ensino e na sua posição como mestre.

Conclui-se ainda que, para que haja de fato um atravessamento pelo discurso psicanalítico, para que haja uma convicção do inconsciente, para aceder ao saber da psicanálise, é preciso passar por sua experiência, pelo divã, pelo trabalho do inconsciente. Disso nem Freud, nem Lacan, nem eu, aqui neste ensaio, não cedemos. Porém é possível que um ensino reverbere, tenha efeitos, inclusive de transmissão. É possível que a presença do discurso psicanalítico, na interlocução com a educação, possa fazer questão; fazer questão para aquele educador que, de certa forma, for fisgado, por um significante, fisgado por uma pergunta, fisgado mesmo pelo real de sua prática, pelo fracasso que lhe é inerente. E sendo fisgado é possível um questionamento. E ao se questionar quanto a sua prática, ao seu lugar, sua função e seu ato, podemos dizer que sua posição pelo menos sofreu um abalo.

E à psicanálise, assim como aos analistas, cabe permanecer no fio da navalha, sustentando sua posição marginal, não prescindindo do real. Este é o lugar da psicanálise na cultura, no mundo. É fazer valer aquilo que o discurso psicanalítico subverte, é apontar o furo sem tamponá-lo, trabalhando a partir dele.

Os psicanalistas podem sim, numa interlocução, oferecer aos educadores sua escuta. E a psicanálise pode oferecer à educação, nessa interlocução, sua leitura, seus significantes, seu texto, seu discurso, sua subversão. Essa é a aposta ao final.

E assim, chego ao final, ao fim desse escrito, que de certa forma tenta fazer um bordeamento do real que se apresenta nessa interlocução. Chego ao fim mantendo aberta a pergunta quanto o que pode um psicanalista na extensão, na interlocução com outros campos de saber, na interlocução com a educação. Chego ao fim mantendo aberto o trabalho.

E, se aceder ao saber psicanalítico não é pouca coisa, como nos aponta Lacan, pois é preciso inventá-lo, aqui também chegamos ao fim apostando na invenção. Não na invenção de um saber novo a ser construído com o seu próprio como no trabalho de análise, mas, sim, uma 
aposta em uma nova maneira de se operar com o saber que lhe é próprio. Essa é a aposta na subversão do "ensino" e do "mestre", uma aposta no efeito de transmissão que aí pode haver.

É este o fim desse trabalho na interlocução da psicanálise com a educação, desse trabalho no qual um significante (psicanálise) representa o sujeito para outro significante (educação). Precipitar-me nessa conclusão faz um corte que num só golpe fecha, mas também faz uma abertura na cadeia e permite que desse trabalho uma nova representação desse sujeito se faça, para um novo significante.

E se o ato da escrita, de fato, dá-se sempre por linhas tortas, façamos ainda uma última aposta. De que este escrito possa servir de isca para o leitor atento, pois essa experiência de escrita teve para seu autor valor e efeito de formação, por se colocar aqui no trabalho do inconsciente. 
Bibliografia e Referências Bibliográficas 
1. ALMEIDA, Orris. O Ato Freudiano e a cidade. In: Revista do Ato Freudiano, ano IV, número 3. Juiz de Fora: 2008.

2. BARROS, Iara Maria Machado. Saber e Conhecimento: hiância e articulações. In: Revista Letra Freudiana - A criança e o saber. Ano XVII, número 23. Rio de Janeiro: Revinter, 1999.

3. BREUER, Joseph. Caso Clínico - Anna O. (1893-1895). In: Obras psicológicas completas de Sigmund Freud. Rio de Janeiro: Imago, v. II, 1996.

4. CIFALI, Mireille. Psicanálise e escritura da história em Michel de Certeau. In: MRECH, Leny M. (org.). O Impacto da psicanálise na educação. São Paulo: Avercamp, 2005.

5. COHEN, Ruth Helena Pinto. Quem tem medo do fracasso? Scielo.

6. COUTO, Mia. O gato e o escuro. São Paulo: Companhia das Letrinhas, 2008.

7. ECKERT-HOFF, Beatriz M. O dizer da prática na formação do professor. Chapecó: Argos, 2002.

8. FERREIRA, Aurélio Buarque Holanda. Novo Aurélio Século XXI: o dicionário da língua portuguesa. Rio de Janeiro: Nova Fronteira, 2002.

9. FERREIRA, Tânia. Freud e o ato do ensino. In: LOPES, Eliana M. (org.). A psicanálise escuta a educação. Belo Horizonte: Autêntica, 2001.

10. FILHO, José Batista de Mendonça. Ensinar: do mal-entendido ao inesperado da transmissão. In: LOPES, Eliane M. (org). A psicanálise escuta a educação. Belo Horizonte: Autêntica, 2001.

11. FONTES, Ana Maria M. A dificuldade para exercer a função de ensinar. In: Educação em Foco - Psicanálise e Educação. Juiz de Fora: Editora UFJF, v. 11, n. 2, set 2006/fev 2007.

12. FOUCAUlT, Michel. História da Sexualidade 1 - A vontade de saber. Rio de Janeiro: Edições Graal, 1988.

13. FOUCAULT, Michel. O que é um autor? Rio de Janeiro: Passagens, 1992.

14. FREUD, Sigmund. (1900) Carta a Wilhelm Fliess de 26/01/1900. Tradução: Paulo Becker. In: Revista Letra Freudiana - Centelha freudiana. Rio de Janeiro: 7Letras, ano XXVI, n. 38, 2007.

15. FREUD, Sigmund. (1905) Sobre a psicoterapia. In: Obras psicológicas completas de Sigmund Freud. Rio de Janeiro: Imago, v. XIII, 1996.

16. FREUD, Sigmund. (1927) Fetichismo. In: Obras psicológicas completas de 
Sigmund Freud. Rio de Janeiro: Imago, v. XXI, 1996.

17. FREUD, Sigmund. (1938) A cisão do eu no processo de defesa. In: Obras psicológicas completas de Sigmund Freud. Rio de Janeiro: Imago, v. XXIII, 1996.

18. FREUD, Sigmund. (1912) A dinâmica da transferência. In: Obras completas de Sigmund Freud. Rio de Janeiro: Editora Delta, v. X, 1958.

19. FREUD, Sigmund. (1915) Observações sobre o "amor de transferência". In: Obras completas de Sigmund Freud. Rio de Janeiro: Editora Delta, v. X, 1958.

20. FREUD, Sigmund. (1918) História de uma neurose infantil. In: Obras completas de Sigmund Freud. Rio de Janeiro: Editora Delta, v. XVI, 1958.

21. FREUD, Sigmund. (1939) Moisés e o Monoteísmo: Três Ensaios. In: Obras psicológicas completas de Sigmund Freud. Rio de Janeiro: Imago, v. XXIII, 1996.

22. FREUD, Sigmund. (1913) Totem e Tabu. In: Obras completas de Sigmund Freud. Rio de Janeiro: Editora Delta, v. XIV, 1958.

23. FREUD, Sigmund. (1894) As neuropsicoses de defesa. In: Obras completas de Sigmund Freud. Rio de Janeiro: Editora Delta, v. II, 1958.

24. FREUD, Sigmund. (1899) As recordações encobridoras. In: Obras completas de Sigmund Freud. Rio de Janeiro: Editora Delta, v. II, 1958.

25. FREUD, Sigmund. (1896) Novas observações sobre as neuropsicoses de defesa. In: Obras completas de Sigmund Freud. Rio de Janeiro: Editora Delta, v. II, 1958.

26. FREUD, Sigmund. (1898) A sexualidade na etiologia das neuroses. In: Obras completas de Sigmund Freud. Rio de Janeiro: Editora Delta, v. II, 1958.

27. FREUD, Sigmund. (1900) Interpretação dos sonhos - tomo I. In: Obras completas de Sigmund Freud. Rio de Janeiro: Editora Delta, v. III, 1958.

28. FREUD, Sigmund. (1900) Interpretação dos sonhos - tomo II. In: Obras completas de Sigmund Freud. Rio de Janeiro: Editora Delta, v. IV, 1958.

29. FREUD, Sigmund. (1908) A moral sexual "cultural" e o nervosismo moderno. In: Obras completas de Sigmund Freud. Rio de Janeiro: Editora Delta, v. V, 1958.

30. FREUD, Sigmund. (1905) Uma teoria sexual. In: Obras completas de Sigmund Freud. Rio de Janeiro: Editora Delta, v. VIII, 1958.

31. FREUD, Sigmund. (1915). Os instintos e seus destinos. In: Obras completas de Sigmund Freud. Rio de Janeiro: Editora Delta, v. VIII, 1958.

32. FREUD, Sigmund. (1920) Mais além do princípio do prazer. In: Obras completas de Sigmund Freud. Rio de Janeiro: Editora Delta, v. VIII, 1958.

33. FREUD, Sigmund. (1927) O Futuro de uma ilusão. In: Obras completas de Sigmund 
Freud. Rio de Janeiro: Editora Delta, v. X, 1958.

34. FREUD, Sigmund. (1910) Esquema de Psicanálise. In: Obras completas de Sigmund Freud. Rio de Janeiro: Editora Delta, v. X, 1958.

35. FREUD, Sigmund. (1909) Análise da fobia de um menino de cinco anos. In: Obras completas de Sigmund Freud. Rio de Janeiro: Editora Delta, v. XV, 1958.

36. FREUD, Sigmund. (1933) Novas contribuições à Psicanálise - Feminidade. In: Obras completas de Sigmund Freud. Rio de Janeiro: Editora Delta, v. XVII, 1958.

37. FREUD, Sigmund. (1933) Novas contribuições à Psicanálise - Explicações, Aplicações e Orientações. In: Obras completas de Sigmund Freud. Rio de Janeiro: Editora Delta, v. XVII, 1958.

38. FREUD, Sigmund. (1933) Novas contribuições à Psicanálise - Uma concepção de universo. In: Obras completas de Sigmund Freud. Rio de Janeiro: Editora Delta, v. XVII, 1958.

39. FREUD, Sigmund. (1933[1932]). Por que a Guerra? In: Obras psicológicas completas de Sigmund Freud. Rio de Janeiro, Imago, v. XXII, 1996.

40. FREUD, Sigmund. (1913) Múltiplo interesse da psicanálise. In: Obras completas de Sigmund Freud. Rio de Janeiro: Editora Delta, v. XVII, 1958.

41. FREUD, Sigmund. (1914) Algumas reflexões sobre a psicologia do escolar. In: Obras psicológicas completas de Sigmund Freud. Rio de Janeiro: Imago, v. XIII, 1996.

42. FREUD, Sigmund. (1925) Prefácio à Juventude Desorientada, de Aichhorn. In: Obras psicológicas completas de Sigmund Freud. Rio de Janeiro: Imago, v. XIX, 1996.

43. FREUD, Sigmund. (1936) Um distúrbio de memória na Acrópole. In: Obras psicológicas completas de Sigmund Freud. Rio de Janeiro: Imago, v. XXII, 1996.

44. FREUD, Sigmund. (1936) Carta a Romain Rolland - Uma perturbação da lembrança na Acrópole. Tradução: Eduardo Vidal. In: Revista Letra Freudiana - Freud entre nós. Rio de Janeiro: 7Letras, ano VIII, n. 6, 1989.

45. FREUD, Sigmund. (1930) O mal-estar na civilização. In: Obras psicológicas completas de Sigmund Freud. Rio de Janeiro: Imago, v. XXI, 1996.

46. FREUD, Sigmund. (1914) A história do movimento psicanalítico. In: Obras psicológicas completas de Sigmund Freud. Rio de Janeiro, Imago, 1996, v. XIV.

47. FREUD, Sigmund. (1919) O Estranho. In: Obras psicológicas completas de Sigmund Freud. Rio de Janeiro, Imago, v. XVII, 1996.

48. FREUD, Sigmund. (1937) Analisis terminable e interminable. In: Sigmund Freud Obras Completas. Madrid: Biblioteca Nueva, 2003. 
49. FREUD, Sigmund. (1919). Sobre o Ensino da Psicanálise nas Universidades. In: Obras psicológicas completas de Sigmund Freud. Rio de Janeiro, Imago, v. XVII, 1996.

50. FREUD, Sigmund. (1893-1895). Estudo sobre a histeria. In: Obras psicológicas completas de Sigmund Freud. Rio de Janeiro, Imago, v. II, 1996.

51. GÓES, Clara de. Das agruras de escrever um caso clínico. In: Do Real, o que se escreve? Revista da Escola Letra Freudiana, Rio de Janeiro: 7Letras, ano XXVIII, n. 40, 2009.

52. GUTIRRA, Beatriz C. C. O professor freudiano de adolescentes. In: Educação em Foco - Psicanálise e Educação. Juiz de Fora: Editora UFJF, v. 11, n. 2, set 2006/fev 2007.

53. KAUfMANN, Pierre. Dicionário Enciclopédico de Psicanálise - O legado de Freud e Lacan. Rio de Janeiro: Jorge Zahar Editor, 1996.

54. KUHN, Thomas. A Estrutura das Revoluções Científicas. São Paulo: Perspectiva, 2007.

55. KUPFER, Maria Cristina. Freud e a Educação - O mestre do impossível. São Paulo: Editora Scipione, 2007.

56. KUPFER, Maria Cristina. Educação para o Futuro - Psicanálise e Educação. São Paulo: Escuta, 2007.

57. LACAN, Jacques. Proposição de 9 de outubro de 1967 (Segunda versão - "Proposição sobre o psicanalista da Escola"). In: Documentos para uma Escola. Revista da Escola Letra Freudiana, ano I, n. 0, Rio de Janeiro, 1981.

58. LACAN, Jacques. O Seminário: livro 1 - Os escritos técnicos de Freud (1953-1954). Rio de Janeiro: Jorge Zahar Editor, 1986.

59. LACAN, Jacques. O Seminário: livro 4 - A relação de objeto (1956-1957). Rio de Janeiro: Jorge Zahar Editor, 1995.

60. LACAN, Jacques. O Seminário: livro 16 - De um Outro ao outro (1968-1969). Rio de Janeiro: Jorge Zahar Editor, 2008.

61. LACAN, Jacques. O Seminário: livro 17 - O avesso da psicanálise (1969-1970). Rio de Janeiro: Jorge Zahar Editor, 1992.

62. LACAN, Jacques. (1953) Função e campo da fala e da linguagem em psicanálise. In: Escritos. Rio de Janeiro: Jorge Zahar Editor, 1998.

63. LACAN, Jacques. (1957) A psicanálise e seu ensino. In: Escritos. Rio de Janeiro: Jorge Zahar Editor, 1998. 
64. LACAN, Jacques. (1956) Situação da psicanálise e formação do psicanalista em 1956. In: Escritos. Rio de Janeiro: Jorge Zahar Editor, 1998.

65. LACAN, Jacques. A instância da letra no inconsciente ou a razão desde Freud. In: Escritos. Rio de Janeiro: Jorge Zahar Editor, 1998.

66. LACAN, Jacques. (1958) A direção do tratamento e os princípios de seu poder. In: Escritos. Rio de Janeiro: Jorge Zahar Editor, 1998.

67. LACAN, Jacques. (1960) Subversão do sujeito e dialética do desejo no inconsciente freudiano. In: Escritos. Rio de Janeiro: Jorge Zahar Editor, 1998.

68. LACAN, Jacques. (1960-1964) Posição do inconsciente no Congresso de Bonneval. In: Escritos. Rio de Janeiro: Jorge Zahar Editor, 1998.

69. LACAN, Jacques. (1964) Do "Trieb" de Freud e do desejo do psicanalista. In: Escritos. Rio de Janeiro: Jorge Zahar Editor, 1998.

70. LACAN, Jacques. (1965-1966) A ciência e a verdade. In: Escritos. Rio de Janeiro: Jorge Zahar Editor, 1998.

71. LACAN, Jacques. (1964-1965) Problemas cruciais para a psicanálise. In: Outros Escritos. Rio de Janeiro: Jorge Zahar Editor, 2003.

72. LACAN, Jacques. (1965-1966) O objeto da psicanálise. In: Outros Escritos. Rio de Janeiro: Jorge Zahar Editor, 2003.

73. LACAN, Jacques. (1967) A psicanálise. Razão de um fracasso. In: Outros Escritos. Rio de Janeiro: Jorge Zahar Editor, 2003.

74. LACAN, Jacques. (1967) Da psicanálise em suas relações com a realidade. In: Outros Escritos. Rio de Janeiro: Jorge Zahar Editor, 2003.

75. LACAN, Jacques (1970) Radiofonia. In: Outros Escritos. Rio de Janeiro: Jorge Zahar Editor, 2003.

76. LACAN, Jacques. O aturdito. In: Outros Escritos. Rio de Janeiro: Jorge Zahar Editor, 2003.

77. LACAN, Jacques. (1973) Televisão. In: Outros Escritos. Rio de Janeiro: Jorge Zahar Editor, 2003.

78. LACAN, Jacques. O Seminário: livro 11 - Os quatro conceitos fundamentais da psicanálise. (1964) Rio de Janeiro: Jorge Zahar Editor, 2008.

79. LACAN, Jacques. O triunfo da religião - Precedido de Discurso aos Católicos. Rio de Janeiro: Jorge Zahar Editor, 2005.

80. LACAN, Jacques. Meu Ensino. Rio de Janeiro: Jorge Zahar Editor, 2006.

81. LOPES, Benita Lasada A. e PERES, Rossely S. Matheus. Centelha Freudiana. In: 
Revista Letra Freudiana - Centelha Freudiana. Rio de Janeiro: 7 Letras, ano XXVI, n. $38,2007$.

82. LOPES, Eliane M. O professor é um mestre? In: MRECH, Leny M. (org.). O impacto da psicanálise na educação. São Paulo: Avercamp, 2005.

83. LOPES, Eliane M. Da sagrada missão pedagógica. In: LOPES, Eliane, M. (org.). A psicanálise escuta a educação. Belo Horizonte: Autêntica, 2001.

84. MILLOT, Catherine. Freud Antipedagogo. Rio de Janeiro: Jorge Zahar Editor, 2001.

85. PENNA, Lícia M. D. M. Psicanálise e Universidade - Há transmissão sem clínica? Belo Horizonte: Autêntica, 2003.

86. PEREIRA, Marcelo Ricardo. O avesso do modelo - Bons professores e a psicanálise. Petrópolis: Editora Vozes, 2003.

87. PEREIRA, Marcelo Ricardo. O relacional e seu avesso na ação do bom professor. In: LOPES, Eliane Marta T. (org.). A psicanálise escuta a educação. Belo Horizonte: Autêntica, 2001.

88. PEREIRA, Marcelo Ricardo. Subversão docente: ou para além da "realidade do aluno". In: MRECH, Leny M. (org.). O impacto da psicanálise na educação. São Paulo: Avercamp, 2005.

89. PIMENTA, Selma e GHEDIN, Evandro (orgs.). Professor Reflexivo no Brasil Gênese e crítica de um conceito. São Paulo: Cortez, 2008.

90. RANCIÈRE, Jacques. O mestre ignorante - Cinco lições sobre a emancipação intelectual. Belo Horizonte: Autêntica, 2007.

91. SAFOUAN, Moustapha. Jacques Lacan e a questão da formação dos analistas. Porto Alegre: Artes Médicas, 1985.

92. SANTOS, Leandro A. R. O que Freud poderia ensinar aos professores? In: Educação em Foco - Psicanálise e Educação. Juiz de Fora: Editora UFJF, v. 11, n. 2, set 2006/fev 2007.

93. TEIXEIRA, Elisa. Notas sobre a emergência do Real na Educação. In: Revista Letra Freudiana. Rio de Janeiro, 7 Letras, número 40, ano XXVIII, 2010.

94. VEGH, Isidoro (org.). Os discursos e a cura. Rio de Janeiro: Companhia de Freud, 2001.

95. VIDAL, Eduardo. A análise leiga, uma questão crucial para a psicanálise. In: Revista Letra Freudiana - A análise é leiga: da formação do psicanalista. Rio de Janeiro: Revinter, ano XXII, n. 32, 2003.

96. VIDAL, Eduardo. Um encontro singular com a Acrópole. In: Freud entre nós. Revista 
da Escola Letra Freudiana. Rio de Janeiro: Revinter, ano VII, n. 6, 1990.

97. VIDAL, Maria Cristina V. Neurose Infantil: uma construção freudiana. In: Revista Letra Freudiana: Escola, Psicanálise e Transmissão. Rio de Janeiro: Revinter, ano XV, n. 19/20, 1996.

98. VOLTOLINI, Rinaldo. As Vicissitudes da transmissão da Psicanálise a educadores. In: Revista Estilos da Clínica, ano 3, col. LEPSI IP/FE - USP, 2002. 